\title{
PROSPECÇÃO DE MÁRMORE PARA CANTARIA EM QUIXABA, MUNICÍPIO DE PIO IX, PI.
}

Dissertação de Mestrado apresentada ao Instituto de Geociências da Universidade de São Paulo

Orientador:

Prof. Dr. Reinholt Ellert

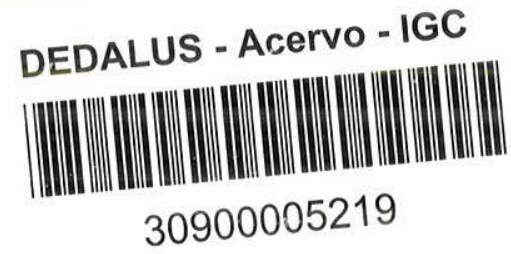


RESUMO

A Jazida de Märmore de Quixaba, no Piauí, era de economicidade controvertida para cantaria em vista do fraturamento do maciço e das impurezas da rocha aflorante.

Investigações sobre a 1itologia, estrutura e geomorfologia da ảrea mostraram que essas feições são notáveis apenas nos afloramentos, com fortes expressões topogräficas locais, enquanto que nas porções baixas do corpo de rochas carbonảticas ocorrem rochas maciças e puras.

Neste trabalho são discutidos os condicionantes geológicos, petrológicos e geomorfológicos identificados e os critérios de prospecção e caracterização tecnológica aplicados ao desenvolvimento e aproveitamento da jazida.

A grande variedade química de rochas, com propriedades físicas semelhantes, industrializadas e comercializadas por profissionais de formação não geocientífica, tem motivado o uso de termos ambíguos que dificultam o cômputo de dados e a avaliação do desempenho econômico do setor das cantarias.

Como contribuição ao estabelecimento de uma nomenclatura clara e precisa é apresentada uma classificação das rochas para a construção civil que correlaciona conceitos petrológicos, industriais e comerciais. Ainda, à luz dos poucos e esparços dados disponíveis, ê feita uma anä1ise do mercado nacional e internacional do märmore como pedra de cantaria: 
RESUMO

\section{INDICE}

1 - INTRODUÇÃO

1.1 - Proposta do autor

1.2 - Fundamentos da proposta

1.3 - objetivos do trabalho

1.4 - Conteüdo do trabalho

4

1.5 - Agradecimentos

2 - generalidAdEs SOBRE O MATERIAL EStudAdO

2.1 - Conceito de märmore, cantaria, rocha e pedra

2.2 - Classificação das cantarias

2.3 - Fases da produção de cantarias

2.4 - Qualificação das rochas para cantaria

2.5 - Uso das rochas na construção

3 - GEOLOGIA DAS ROCHAS CARBONÄTICAS

3.1 - Mineralogia dos carbonatos

3.2 - Físico-química da sedimentação carbonätica

3.3 - Geotectônica das rochas carbonäticas

3.4 - Petrologia das rochas carbonáticas

3.5 - Estägios geológicos das rochas carbonäticas

3.6 - Prospecção de rochas carbonäticas para cantaria 
4 - PROSPECÇÃO DE MẢrMORE PARA CANTARIA EM QUIXABA

4.1 - Localização geogrä́fica da jazida

4.2 - Fisiografia da ärea

4.3 - Evolução dos conhecimentos sobre a jazida

4.4 - Trabalhos recentes em Quixaba

5 - CONCLUSÕES

6 - BIBLIOGRAFIA

\section{INDICE DAS ILUSTRAÇÕES}

\section{FOTOS}

Foto 1 - Estrutura a que pertence a jazida de mármore de Quixaba.

Foto 2 - Vista de uma das elevações de rochas carbonáa ticas impuras e fraturas contra as rochas si 1 icảticas .

Foto 3 - Vista geral de uma frente de desmonte mostrando o flanco abrupto das elevações de mär more impuro e fraturado, contra a porção de märmore branco e maciço coberta por solo averme 1 hado.

Foto 4 - Vista da escarpa de uma das elevações mostrando o fraturamento horizontal e as canelu ras.

Foto 5 - Horizontes de nỏdulos silicâticos intercalados concordantemente no corpo de mármore de Quixabà.

\section{FIGURAS}

Figura 1 - Evolução da produção brasileira de mảrmore, em toneladas.

Figura 2 - Evolução das reservas brasileiras de märmore, em toneladas. 
Figura 3 - Evolução do comërcio exterior brasileiro de mảrmore, em toneladas.

Figura 4 - Conteủdo porcentual dos ions carbonato e bi carbonato na ảgua do mar de salinidade de $35^{\circ} / 00$.

Figura 5 - Correlação do conteủdo de calcảrio com a profundidade oceânica .

Figura 6 - Correlação da natureza física e química dos sedimentos geossinclinais com os movimentos tectônicos da Região Atlântica.

Figura 7 - Classificação das rochas carbonäticas quanto à composição químico-mineralögica.

Figura 8 - Localização geogräfica da jazida de märmore de Quixaba.

Figura 9 - Sintese geológica e estrutural da região su deste do Piauí, sudoeste do Ceara e noroes te de Pernambuco. Figura 10 - Sintese geolögica e estrutural fotointerpre
tada da região de Quixaba.

Figura 11 - Mapa geolỏgico de parte do corpo de mârmore de Quixaba.

Figura 12 - Seção geológica atravês do corpo de mảrmore de Quixaba, segundo a linha $500 \mathrm{~N}$.

Figura 13 - Difratogramas de raios-X de algumas amostras de mảrmore de Quixaba.

Figura 14 - Diagramas de frequência das fraturas para as porções norte e sul do corpo de mármore de Quixaba.

\section{QUADROS}

Quadro 1 - Grafia do termo "marmore" em värios idiomas

Quadro 2 - Classificação das roçhas para construção quanto à natureza química, mineralögica e geológica.

Quadro 3 - Classificação das rochas carbonảticas quanto à aplicação. 
Quadro 4-Classificação das rochas silicảticas quanto à ap1icação.

Quadro 5 -Etapas da produção de materiais de cantaria. 22

Quadro 6-Periódicos especializados em materiais de cantaria do mundo.

Quadro 7 - Tipos de rochas considerados nas sucessivas edições do Anuário Mineral Brasileiro que tem aplicações como cantaria.

Quadro 8 - Produção brasileira de märmore para cantaria, em toneladas.

Quadro 9 - Evolução das reservas brasileiras de märmore na dêcada de 1970, em toneladas.

Quadro 10 -Evolução do comércio exterior brasileiro de mármore para cantaria, em toneladas.

Quadro 11 - Dados de 1974 sobre rochas de construção de alguns países, em toneladas.

Quadro 12 - Correlação cristalogräfica dos carbonatos acidos dos metais bivalentes com seus raios atômicos.

Quadro 13 - Conteủdo aniônico formador de carbonatos em ảguas marinhas e fluviais.

Quadro 14 - Conteủdo catiônico formador de carbonatos em äguas marinhas, a $25^{\circ} \mathrm{C}$ e seus produtos de solubilidade.

Quadro 15 -.Classificação das rochas carbonāticas.

Quadro 16 - Atividades para avaliação de uma jazida de rocha para cantaria.

Quadro 17 - Resultados de exames petrogräficos de amostras de rochas de Quixaba.

Quadro 18 -Características tecnológicas de märmore de Quixaba. 


\section{1 - INTRODUÇÃO}

1.1 - Proposta do Autor

Como geölogo de mineração, enfrentando problemas de disponibilidade de recursos capazes de atender à demanda e às especificações industriais, ao empreender o Curso de Pōs-Graduação a proposição foi realizar um trabalho 1igado ao desenvolvimento de jazidas.

Dos tipos de minerais e de depósitos com que tem trabalhado, tais como de cobre e de cromo associados a rochas bäsicas-ultrabäsicas, de manganês, de pegmatitos 1itiniferos, de quartzitos puros, de argilas especiais, de sódio e potảssio, o de märmore para cantaria é o que revelou aspectos mais interessantes para a realização de um trabalho que coadunasse com a meta estabelecida e pudesse ser apresentado como Dissertação de Mestrado.

A atuação no setor de pedras de cantaria permitiu a inteiração com problemas relativos à geologia de seus jazimentos, para cuja solução foi necessärio estabelecer uma metodologia especifica. São os resultados desse trabalho que o autor se propõe a apresentar.

\section{2 - Fundamentos da Proposta}

A idëia de desenvolver esse tema nasceu da problemätica vivida durante as investigações de reavaliação da Jazida de Märmore de Quixaba, no Piaui. As opiniões acerca de um empreendimento mineiro no local eram controvertidas em vista do fraturamento do maciço e das impurezas da rocha observadas nos värios afloramentos da ärea. 
Por ocasião do início das atividades, em 1976, para uma abordagem adequada das feições-problemas da jazida, foi procurado um esquema de prospecção que auxiliasse nos levantamentos. Dessa busca foi constatado que, enquanto fartam recursos para o beneficiamento, comercialização e conservação da pedra, são raras as publicações técnicas sobre pesquisas de recursos e sobre a abertura de frentes de extração. Consequentemente, enquanto as atividades de tratamentọ da pedra jâa alcançaram alto grau de sofisticação, o desenvolvimento de reservas deixa muito a desejar, constituindo o ramo da mineração mais carente de tecnologia.

Apesar da utilização das rochas para construção se dar sob värias formas e com diferentes finalidades, qualquer frente de extração ê tratada como pedreira, caracterizada pelo empirismo que norteia seu desenvolvimento e aproveitamento.

O fato tem acarretado uma série de problemas relacionados à geologia do jazimento, principalmente quando se trata de märmore para cantaria, quando a rocha $\vec{e}$ utilizada na forma maciça, o que exige maior seleção do material na fonte. Nesses casos o sucesso de uma iniciativa nara aproveitamento da rocha depende do perfeito conhecimento do depösito.

Com as atividades em Quixaba foi constatado que parte dos problemas que afetam o setor das rochas de construção, e em particular o de märmore para cantaria, è de ordem terminológiça. Alēm de termos ambíguos, não existe uma classificação industrial simples, funcional e precisa situando as cantarias dentre os demais materiais rochosos e materiais de construção. Assim, a compilação e o tratamento estatístico dos dados têm sido prejudicados, impossibilitando a realização de diagnósticos e prognósticos realistas sobre o setor. 
Preocupado com a desatenção das instituições técnicas e administrativas e com a falta de planejamento para as rochas de construção, na maioria dos paises, que são recursos não-renovāveis; o Centre for Natural Resources, Energy and Transport, do Department of Economic and Social Affairs, do United Nations Secretariat, clama por providências enérgicas e imediatas no sentido de desenvolvê-1os e aproveitá-1os racionalmente.

Por apresentar feições geológicas, tecnolögicas e mercadolỏgicas em quantidade e variedade consideráve1, jā em fase avançada de conhecimentos, a Jazida de Mârmore de Quixaba presta-se bastante para elucidação do desenvolvimento desse tipo de bem mineral.

0 apelo internacional e o resultado das pesquisas em Quixaba despertaram o interesse pelo assunto e foram decisivos para a escolha do tema desta dissertação.

\section{3 - objetivos do Trabalho}

Um dos objetivos desta Dissertação ê apresentar uma metodologia para prospecção de märmore para cantaria, almejando preencher parte da lacuna causada pela falta de trabalhos na ärea dos condicionantes geológicos de jazidas desse tipo de material.

Esta explanação visa, tambëm, atribuir sentido mais têcnico e científico às atividades de desenvolvimento e aproveitamento dos recursos minerais de märmore para cantaria, contribuindo para maior disponibilidade de material, com qualidade compatível com as demandas interna e externa.

Outro objetivo deste trabalho è chamar a atenção para a importância do setor das cantarias como campo de de- 
senvolvimento tecnológico integrado à aspectos ecológicos e urbanísticos, como meio de emprego de mão-de-obra e como fonte de reservas monetärias.

Sem pretender esgotar o assunto, a finalidade desta Dissertação e suscitar o debate em torno do tema, fazendo com que mais profissionais se interessem por ele e divulguem suas experiências. Com mais elementos para o aproveitamento das pedras de cantaria, é de se esperar maior rentabilidade no processo, maior participação de grupos econômicos, maior oferta de material de melhor qualidade, melhores padrões na construção civil, alêm de se conquistar uma maior parcela do mercado mundial, importante para o fortalecimento da nossa economia.

$$
1.4 \text { - Conteüdo do Trabalho }
$$

São discutidos aqui os condicionantes geológicos do desenvolvimento e aproveitamento de jazidas de märmore para cantaria, com base nos resultados dos estudos em Quixaba.

Como base para o desenvolvimento do tema proposto são feitas considerações sobre a conceituação, classificação, produção, qualificação e utilização do material estudado.

Entendendo que para a conceituação das cantarias seja necessária uma nomenclatura clara e precisa, são discutidos áspectos terminolögicos e classificatörios das rochas e demais materiais de construção, em todas as fases de isua produção.

Pertencentes a outro campo da tecnologia mineral, mas relacionados às feições do jazimento e regulamentadores do uso das rochas, são apresentados os métodos de qualifi- 
cação das rochas, padronizados pela engenharia.

Ainda, na tentativa de apresentar um diagnöstico sobre o setor do märmore como cantaria foram compilados e interpretados os dados disponiveis sobre reservas e produção brasileiras e sobre o mercado internacional em complemento à pesquisa de mercado realizada nas regiões : norte e nordeste do Brasil.

Para maior compreensão dos condicionantes da prospecção e aproveitamento do märmore como cantaria são apresentados aspectos sobre a geologia das rochas carbonäticas correntes na literatura.

Tendo contribuido com grande quantidade de dados para a realização deste trabalho, são descritas as atividades desenvolvidas e são discutidos os resultados obtidos com a avaliação da Jazida de Quixaba.

\section{5 - Agradecimentos}

Quanto mais se especializa em ciência e tecnologia, mais rareiam os trabalhos de autoria exclusiva. Tratando-se de jazidas minerais, quase sempre geograficamente distantes e de abordagens complexas, è praticamente impossíve1 desenvolver-se uma pesquisa completa que não envolva recursos tëcnicos e financeiros de värias instituições e de värios campos de especialização. Assim, esta Dissertação de Mestrado não teria sido realizada não fosse a sinceridade e dèspretenção dos colaboradores.

Logo após o encerramento dos trabalhos de campo, foi-me dada permissão para utilização dos dados, de propriedade da Companhia de Desenvolvimento do Piauí - COMPEDI, na época sob a presidência do geólogo Aurimar de Barros Nunes. 
Do Piauí, tambẻm foi grande a colaboração do geỏlogo César Negreiros Barros Filho, que informou os resultados das atividades em Quixaba, entre o término das pesquisas de campo e a conclusão desta. Importante, igualmente, foi a ajuda dos moradores do local, encarregando-se do ärduo serviço de marreta, escavação de poços e porte das amostras sob o sol escaldante do sertão.

Os incentivos e as facilidades concedidas pelo Instituto de Pesquisas Tecnolögicas do Estado de São Paulo S.A. - IPT, em especial pela Divisão de Minas e Geologia Aplicada - DMGA, foram de grande valor. Na DMGA foi notāvel a contribuição dos geölogos, engenheiros e técnicos do Agrupamento de Geologia Geral, do Agrupamento de Minas, do Agrupamento de Petrologia, do Agrupamento de Documentação e da Seção de Desenho.

Outra grande contribuição foi prestada pelos que se ocuparam da datilografia e revisão do texto que prefiriram ficar no anonimato.

Este trabalho não teria sido realizado não fosse a orientação do Professor Doutor Reinholt Ellert, mestre conselheiro desde o Curso de Graduação, a quem devo muito de minha carreira profissional.

Ficam a todos sinceros agradecimentos. 
2 - generalidAdES SOBRE O MATERIAL ESTUdAdO

2.1 - Conceito de Märmore, Cantaria, Rocha e Pedra

A palavra "märmore" ē derivada do termo latino "marmor", ou "marmore", oriundo, por sua vez, do grego "marmairein", ou "marmaros", que significa "reluzente".Acredita-se que essa terminologia tenha sido determinada pelas rochas de rara beleza estética e fảcil trabalhabilidade, adequadas à construção e ornamentação, que chamaram a atenção dos habitantes de Roma e Grécia antigas.

Sendo ainda desconhecidas as feições físicas e quỉmicas das rochas, crê-se que tal conceituação tenha sido inconscientemente relacionada às rochas carbonảticas metamorfizadas, típicas do cinturão orogênico que atravessa as regiões onde floresceram aquelas civilizações.

Com sua mentalidade expansionista, os romanos difundiram o uso da pedra entre os povos do ocidente da Europa, fazendo com que a correspondente designação tivesse a mesma raiz em quase todos os idiomas (Quadro 1). Entretanto como as novas regiões ocupadas apresentavam constituições litológicas diversas, os conquistadores foram obrigados a utilizar as rochas então disponíveis. Apesar das aparências diferentes, muitas das novas rochas mostravam seme1hanças com as conhecidas na pátria, motivo pelo qual elas foram denominadas "märmores graníticos" (MOTINOT, 1973). Com isso, o significado petrológico original do termo "mārmore" foi alterado. Com um sentido industrial, ou comercial, passou a compreender toda rocha apropriada para construção e ornamentação.

Com o desenvolvimento da Mineralogia e Petrologia, 


\begin{tabular}{|c|c|}
\hline \multicolumn{2}{|c|}{ QUADRO 1 } \\
\hline GRAFIA DO TERMO "MARMORE" EM VĀRIOS IDIOMAS \\
\hline GRAFIA & IDIOMA \\
\hline marble & inglês \\
marbre & francês \\
marmer & holandês \\
marmo & italiano \\
marmol & espanhol \\
marmor & alemão \\
marmor & suêco \\
mpamop & russo \\
marmur & polonês \\
marmura & rumeno \\
márväny & hünaro \\
\hline
\end{tabular}

mormente a partir dos Séculos XVII e XVIII, e o reconhecimento das propriedades físicas e químicas das rochas, o termo "mármore" passou a ser utilizado com várias conotações, nos diversos países, conforme a formação têcnica de quem o emprega. Enquanto os profissionais ligados às geociências (geôlogos, petrólogos) tendem a mantê-1o como designação de rochas carbonäticas metamórficas, os demais têcnicos que trabalham com rochas (engenheiros civis, arquitetos, comerciantes) conservam a conceituação quanto à aplicabilidade. Por isso MAMET \& D'ALBISSIN (1967) recomendam cuidado na utilização da palavra e que sejam preferidas as denominações compostas de Grubenman e de Holmes. Em 1910, Grubenman criou um esquema de denominação baseada nos minerais aces- 
sórios, como forsterita-märmore, diopsídio-mārmore, e em 1920, Holmes sugeriu uma denominação em função do grau de metamorfismo, como epi-mármore, cata-mārmore.

Petrologicamente, a conceituação de "mārmore" tem sido baseada na natureza química (químico-mineralógica), na natureza física (grau de cristalinidade, coesividade, resistividade mecânica) e no jazimento da rocha (metamörfico). No entanto por se tratarem de parâmetros amplamente variảveis, não tem havido uniformidade no emprego da nomenclatura, mesmo entre os profissionais das geociências das värias nacionalidades.

Para os americanos, conforme definição dada por Dana em meados do SéculoxIX, "mảrmore" é uma rocha metamórfica constituída, principalmente, de calcita e de dolomita. (HURLBUT, 1941.) Trata-se, portanto, de um conceito petrológico, também adotado por JUNG (1963), MIYASHIRO (1975), WINKLER (1977), AZAMBUJA \& SILVA (1977) e outros geólogos de todo o mundo.

Para os europeus, de acordo com a definição de Harker no começo do Século XVIII, "mármore é calcārio crista1ino, independentemente de sua natureza sedimentar ou metamörfica" (MAMET \& D'ALBISSIN, 1967). Essa conceituação tem sido mais usada, comercialmente, para designar um conjunto de rochas cristalinas constituídas de calcita, dolomita e serpentina, suscetíveis de polimento (HURLBUT, 1941; POWER, 1975; SHELTON \& DRAKE, 1975; AZAMBUJA \& SILVA, 1977) e que pela estêtica agradảve1, podem ser usadas como elemento estrutural e ornamental na construção civil. Esse é o sentido comumente utilizado pelos engenheiros civis, arquitetos, comerciantes e construtores, para quem importam só as características tecnológicas da rocha.

Com a introdução da suscetibilidade ao polimento nà conceituação de "märmore", por Jacques Lapparent, em 1923. 
(MENDES, 1974), ficou indiretamente estabelecido o conceito de "cantaria". A palavra é composta do prefixo "canto = pedra preparada para formar o ângulo de uma construção = esquadria de pedra" proveniente do grego "kanthōs", ou do latim "kanthus", que significa "ângulo, aresta", e pelo sufixo "aria = atividade" (FERREIRA, 1975). E, o profissiona 1 das cantarias ê chamado "canteiro".

Como o polimento $\vec{e}$ uma característica física comum à muitas rochas cristalinas, sejam elas de origem ígnea, sedimentar ou metamörfica, o grupo dos materias de cantaria engloba uma sẻrie de termos litológicos física e quimicamente diferentes. Dessa forma, em lugar de contribuir para a solução do problema terminológico, ele aumentou os pontos de conflito na utilização da palavra "märmore". MENDES (1974) cita que, na França, Paul Dumont tratou exaustivamente dessa questão, tendo chegado a sugerir que o vocábulo fosse banido da literatura para evitar situações indesejảveis de desprezo a determinadas rochas de valor. MENDES cita que Dumont sugeriu igualmente que, por possuir interesse econômico, o märmore seja considerado "minêrio" e não apenas como "rocha". MENDES continua dizendo que, menos radicais que Dumont, mas tambẻm interessados na solução do problema, Motinot e a Federação Marmorista Francesa sugeriram, respectivamente, a utilização do substantivo latino "marmor" e do adjetivo "marmóreo" para designarem o conjunto de rochas suscetíveis ao polimento.

Sem uma terminologia clara e precisa, algumas instituições de normas de materiais de construção têm usado o termo "märmore" como sinônimo de "calcārio cristalino". E a distinção entre värios tipos comerciais de rochas é feita por adjetivação, de forma a bem caracterizä-1os por uma de suas feições típicas. Por vezes, as características inerentes a certos tipos tradicionais de rochas são conhecidas pelo seu local de origem. Assim, numa versão modernizada de Grubenman, esse é o esquema de denominação adotado nos catä- 
logos da VERMONT MARBLE COMPANY (1971), do BUILDING STONE INSTITUT (1972), da ITALIAN MARBLE INDUSTRIE (1972, do Departamento Nacional da Produção Mineral (AZAMBUJA \& SILVA, 1977). Citam-se como exemplos brasileiros dessa nomenclatura o märmore branco cintilante, o mármore ônix ouro, o mármore rosa bahia, o märmore branco espírito santo e outros.

Neste trabalho, o termo "märmore" terả conotação exclusivamente petrológica, compreendendo rochas carbonáticas cristalinas de jazimentos metamórficos.

Rochas carbonáticas são aquelas compostas essencialmente de minerais carbonatos. Apesar de numerosos, nas rochas de cantaria eles são representados somente por calcita e dolomita.

Do ponto de vista físico, existem dois tipos de rochas carbonáticas: de baixos e de altos graus de cristalinidade.

As primeiras são chamadas genericamente de "calcários", incluindo alguns tipos litológicos conhecidos por travertino, ônix, conchas. Ocorrem em camadas horizontais, resultantes de deposição de clästicos, exibindo textura aglomerätica, porosa, ou de precipitação química, quando são amorfas ou microcristalinas. Os cảlcảrios ocorrem ainda èm corpos tabulares com vārias atitudes, resultantes da ação de esforços sobre as camadas horizontais, com textura microcristalina. Em qualquer caso, são rochas de baixo grau de coesividade, inadequadas para cantaria.

As rochas do segundo grupo são os "märmores" propriamente ditos. Ocorrem em corpos de värias formas e posições, resultantes de ação têrmica de corpos intrusivos próximos. São rochas holocristalinas, densas, de porosidades praticamente nulas e com altas coesividades, bastante apro- 
priadas para cantaria.

Normalmente os calcärios são transformados em märmores por ação de metamorfismo, atravës de recristalização. Como resultado ocorre obliteração de grande parte das feições sedimentares, como a estratificação, porosidade, densidade e coesividade. Enquanto que a porosidade dos calcärios é da ordem de alguns porcentos, a dos märmores é da ordem de centésimos dessa mesma cifra (CHILINGAR, BISSEL \& FAIRBRIDGE, 1967; BATHURST, 1971). Consequentemente, a densidade e a resistência aos esforços mecânicos dos mármores são maiores que as dos calcärios.

Neste trabalho, o termo "cantaria" serả empregado com sentido comercial, compreendendo todos os materiais rochosos passiveis de adquirir lustro pelo polimento.

Quanto aos vocábulos "rocha" e "pedra", embora sejam utilizados como sinônimos, existem diferenças fundamentais em seus significados (BOWLES, 1939; WINKLER, 1975). Enquanto que a palavra "rocha" è aplicada para designar o material bruto, em seu local original, formando maciços, "pedra" é utilizada para indicar porções do material 1ibertado por meio de rupturas naturais, artificiais ou de cortes aprimorados. Em outras palavras, as pedras são fragmentos de rochas com formas rüsticas (lascas) ou com formas esquadrejadas (blocos, paralelepípedos, placas, etc.).

Neste trabalho, para referências aos aspectos tecnolôgicos do material, välido para todo maciço, ê empregado o termo "rocha" e, quando se referir às peças, em qualquer estảgio de industrialização, ê utilizado o termo "pedra". 


\section{2 - Classificação das Cantarias}

A solução para o problema de nomenclatura das cantarias estả numa classificação simples e funcional, que agrupe e correlacione todos os materiais de construção por seus aspectos têcnicos e comerciais.

CURRIER (1960), ERGUVANLI, YƯZER, GÜLEÇ \& ZANBAK (1974), PETRUCCI (1974) e TOURENQ (1974), reconhecendo a importância das rochas para construção, propuseram alguns esquemas, mas somente para certos tipos de materiais e com finalidades específicas.

$\mathrm{Na}$ opinião corrente, a classificação das rochas para construção deve ser baseada em suas naturezas petrológicas ou em suas aplicações. Como as características petrolögicas são funções dos processos formadores da rocha, sua classificação deve ser fundamentada nos princípios geológicos. E como a aplicação depende das naturezas físicas e químicas, nessa chave devem ser correlacionadas a forma e finalidade com que são utilizadas.

A classificação mais geral é a de PETRUCCI (1974). E1e começa dividindo os materiais em artificiais e naturais.

Os materiais de construção artificiais ou sintéticos, são obtidos atravês de processos industriais, a partir de materiais naturais, como as olarias, o cimento, os metais, o vidro; as cerâmicas. Eles não serão analisados neste trabalho por compreenderem outros campos de investigações.

Os materiais de construção naturais são utilizados como encontrados na natureza, exigindo, apenas, modela- 
gem segundo os padrões da obra. São as madeiras e as rochas. Somente as segundas são afins deste trabalho.

Quanto à natureza geológica, ou quanto ao modo de formação, as rochas podem ser não consolidadas ou consolidadas. O primeiro grupo compreende as areias, os cascalhos, as argilas, importantes materiais de construção do campo dos recursos minerais, mas não considerados comercialmente como rochas. Apesar de tratar-se de outro setor de minerais para a construção que clama por maiores estudos, ele não será discutido aqui. O segundo grupo engloba tanto as rochas aglomeräticas (anteriormente não-consolidadas) como as rochas cristalinas.

Quanto à natureza química, ou quanto à composição mineral, as rochas para construção são classificadas em silicáticas e carbonāticas (Quadro 2). Silicáticas são as rochas constituídas, fundamentalmente, de um ou mais minerais silicatos, como quartzo, feldspato, mica, piroxênio, anfibó1io, serpentina, talco. E carbonáticas são as rochas formadas, predominantemente, de um ou mais minerais carbonatos, como calcita, dolomita, magnesita.

Tanto na Europa como nas Amëricas, para designar o grupo de rochas para construção, tem sido usado o termo "pedra de construção" = building stone", compreendendo todas as espëcies tenazes, desde exemplares comuns, até tipos exóticos das mais variadas texturas e composições químico-mineralógicas. A apreciação das rochas de construção, quanto aos aspectos texturais e composicionais, é importante para escolha do material mais adequado à finalidade desejada e consequentemente, obtenção de maior durabilidade da obra.

Quanto à aplicação, as rochas de construção são divididas em brita e talhe. Em geral, as especificações para elas são mais ou menos as mesmas, mas seus mëtodos de 


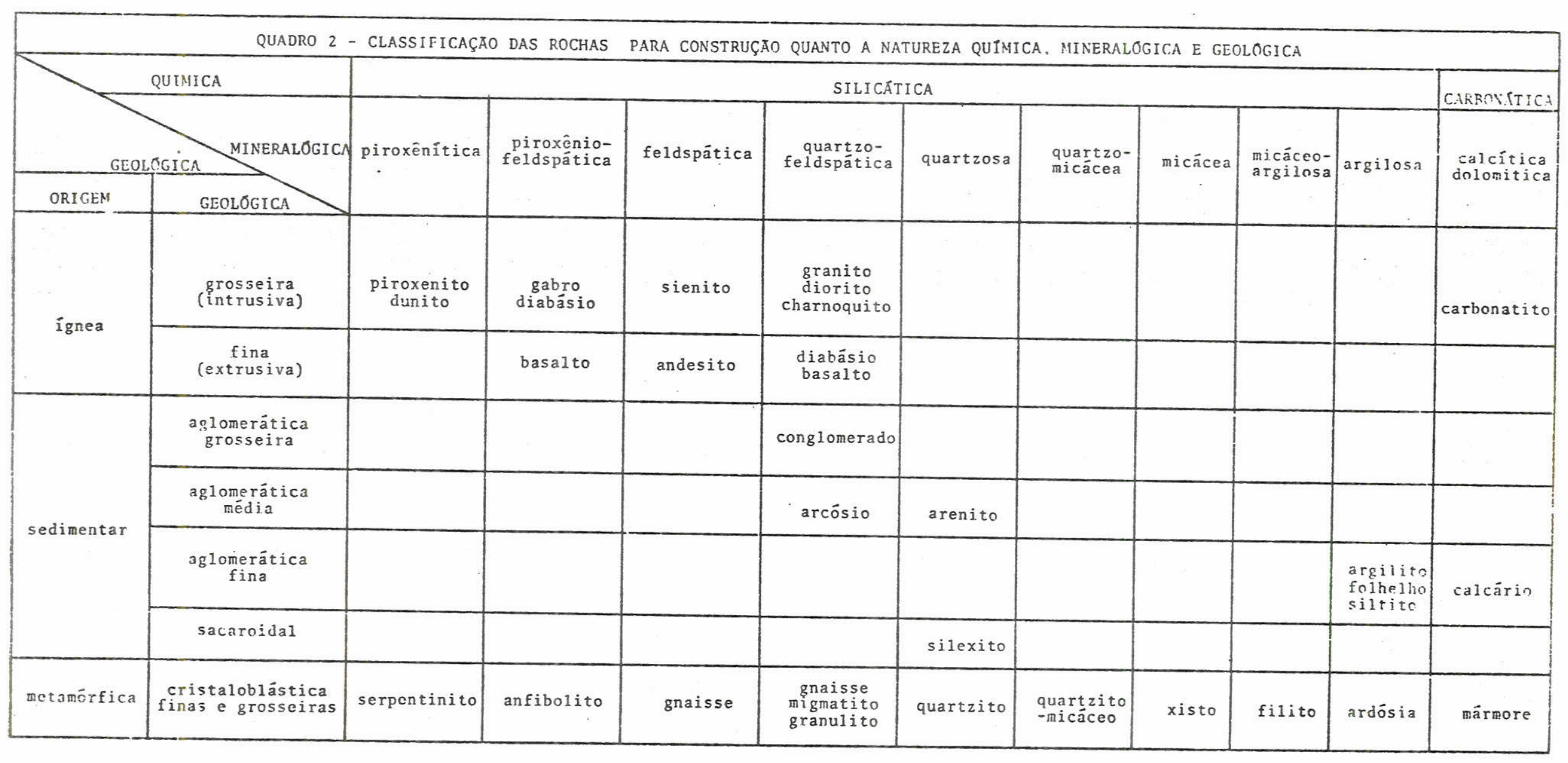


prospecção, extração e beneficiamento são completamente diferentes.

Brita ("crushed stone") è a pedra triturada, em fragmentos de formas irregulares, aproximadamente equidimencionais, e tamanhos dentro de limites prefixados pela engenharia. Ela é utilizada em concreto, lastro de estradas, enrocamentos, etc.

Pedras de talhe ("dimension stone", "pierre de taille") são aquelas que apresentam a propriedade de se partirem segundo direções mais ou menos ortogonais, produzindo blocos ou placas, de superfícies razoavelmente planas. As peças, dependendo da forma e do tamanho, são utilizadas como elemento estrutural em muros, colunas e vigas de edifícios, monumentos, arruamentos, esculturas. As peças menores são chamadas paralelepípedos ("rubble stone"). As placas são utilizadas em coberturas, revestimentos, pisos, tampos. São rochas adequadas para esses fins os granitos,gnaisses, xistos, ardósias, basaltos, quartzitos, arenitos, calcários, mármores. Em qualquer caso, como resultado final de sua utilização, tem-se um acabamento rüstico, conhecido por "alvenaria".

Segundo FERREIRA (1975), antes de passar pelo português antigo "alvanaria", o termo "alvenaria" ẻ originärio do ārabe "al-bannã = alvanel = pedreiro". As designações desse profissional, em francês e inglês, são, respectivamente, "maçon" e "mason". E as correspondências à "alvenaria", nos mesmos idiomas e na mesma ordem, são "maçonnerie" e "mansonry". Essies termos franceses e ingleses têm a mesma raiz grega em "magma = pasta pétrea" e em "massein = amassar com ägua", que antes passaram pelo latim como "macerare" e pelo saxônico como "makon", com sentido de "afeiçoar a terra" (PICOCHE, 1971).

Com alvenaria ẻ erguida uma construção estảve1 
pela justaposição horizontal e vertical desordenada de blocos com variadas formas e tamanhos, ligados ou não por argamassa. Quando sem argamassa, são chamadas alvenarias de pedra seca, mantidas em equilíbrio por ação de cargas exteriores e do próprio peso dos blocos. Se com argamassa, são chamadas alvenaria de pedra argamassada, em que o ligante une as peças preenchendo os vazios, impermeabilizando o maciço e distribuindo os esforços (CAVALCANTI, 1951).

Quando as pedras de talhe puderem ser serradas e polidas, em peças de formas e tamanhos prë-estabelecidos pelos projetos arquitetônicos, recebem o nome de cantaria. 0 corte e o polimento valorizam a peça por imprimirem-lhe faces planas lustrosas, que aumentam a durabilidade e realçam a beleza estética, qualidade fundamental para que a pedra seja utilizada como elemento decorativo. Dessa forma, alëm das propriedades necessārias para a pedra de talhe, as pedras de cantaria devem ser passiveis de corte, polimento e devem apresentar boa aparência. São pedras de cantaria o mármore, granito, gnaisse, serpentinito, muito utilizadas em pisos, revestimentos de interiores e exteriores, em mobiliärios e estatuária.

Diante do grande numero de propriedades comuns a grande variedade de rochas, não existem limites bem definidos entre pedras de talhe e de cantaria. Em geral, toda pedra de cantaria tambēm é pedra de talhe, porém o conträrio nem sempre é verdadeiro. Como exemplo de rochas que servem para alvenaria, mas que não servem para cantaria citam-se o quartzito, arenito, ardósia, xisto.

Entre os americanos (POWER, 1975; SHELTON \& DRAKE, 1975), não $\vec{e}$ feita muita distinção entre pedras de talhe ("dimension stone") e pedras de cantaria("cut stone").

No Brasil, apesar das tentativas de aperfeiçoamen- 
to, os dados sobre as pedras de construção são apresentados globalmente, ora por tipos de rochas, ora por destino dos mesmos, impossibilitando diagnósticos e prognósticos realistas sobre sua demanda e a utilização de cada um deles. Principalmente para os grupos que incluem grande variedade de rochas, com grande número de aplicações, os dados globais deixam de ter significado. E o caso das rochas carbonäticas (calcārios e mārmores) que, alẻm de usos na construção como brita, cantaria e alvenaria, ainda são utilizados na indústria química (cimento que tambêm vai para a construção) na agricultura, na metalurgia. E o caso, também, das rochas quartzosas (quartzitos, arenitos, granitos, gnaisses), que alẻm das inümeras aplicações na construção (brita,alvenaria, cantaria), são aproveitadas como abrasivos, moldes de fundição e matéria prima para indústria de vidro.

Quanto ao destino dos materiais, ẻ norma, nas sucessivas edições do Anuärio Mineral Brasileiro (BRASIL, 1972 a 1980), a reunião de areias e cascalhos com brita; dois tipos de materiais rochosos com mesmos destinos, mas de ocorrências geológicas e de processos de industrialização diferentes. O maior discernimento entre os destinos dados aos vârios materiais rochosos na construção (Quadros 3 e 4) é feito pelo United States Bureau of Mines (UNITED STATES, 1978 $A$ e $B)$.

Para as pedras de cantaria, cujos processos de produção e destinos são iguais para todos os tipos 1itológicos, não hâ inconvenientes na universalização dos dados de produção e consumo, mas, em se tratando do desenvolvimento de reservas, ê preciso tratamento específico para cada espẻcie de rocha (CURRIER, 1960).

2.3 - Fases da Produção de Cantarias

Do maciço rochoso à construção acabada, as rochaś 


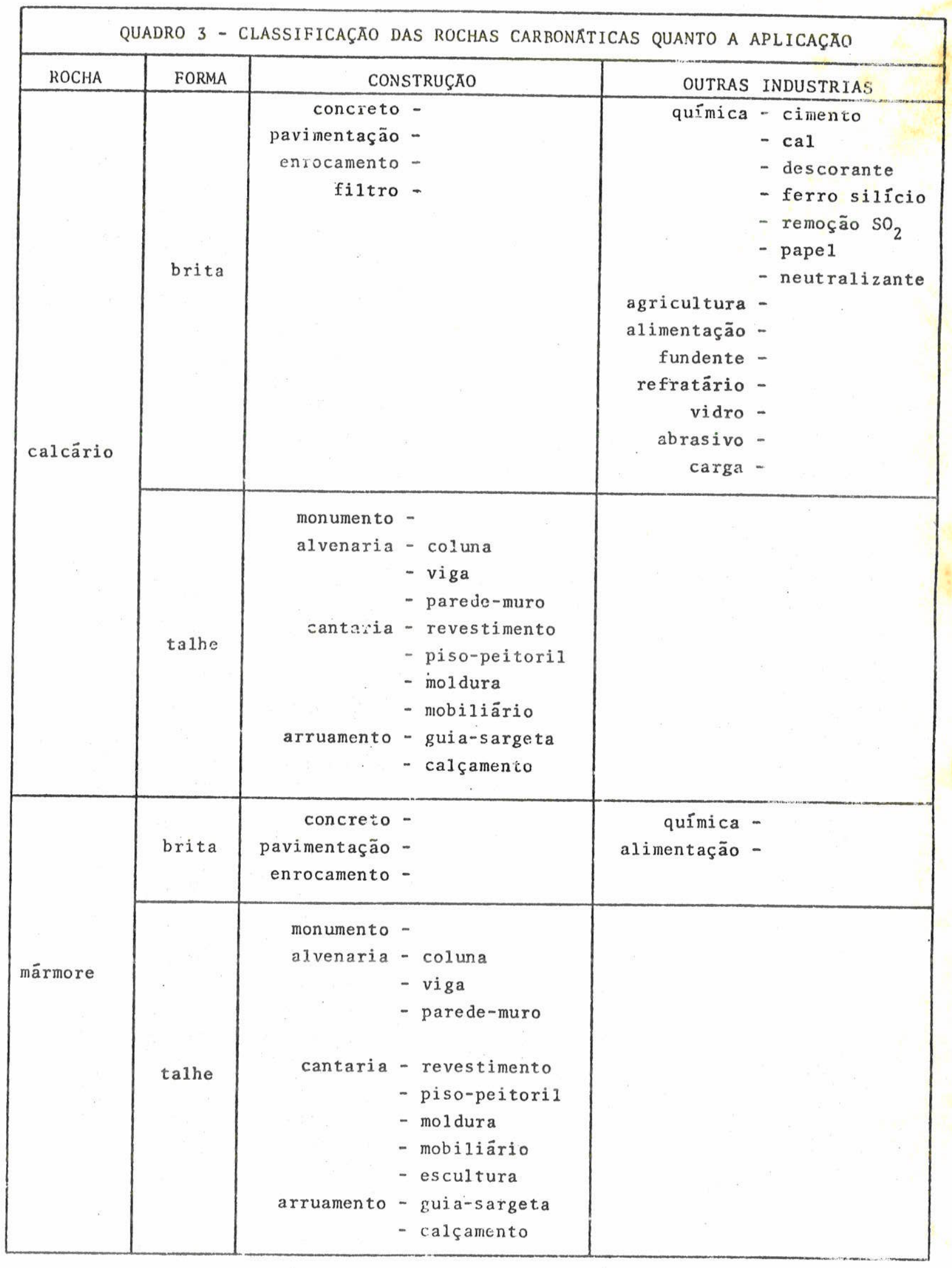




\begin{tabular}{|c|c|c|c|c|}
\hline \multicolumn{5}{|c|}{ APL I CAÇÃO } \\
\hline ROCHA & FORMA & \multicolumn{2}{|c|}{ CONSTRUÇĀO } & OUTRAS \\
\hline \multirow[b]{2}{*}{ granito } & brita & $\begin{array}{r}\text { concreto } \\
\text { pavimentação } \\
\text { enrocamento } \\
\text { filtro }\end{array}$ & $\begin{array}{l}- \\
- \\
- \\
-\end{array}$ & $\begin{array}{c}\text { alimentação } \\
\text { carga }\end{array}$ \\
\hline & talhe & $\begin{array}{l}\text { monumento } \\
\text { alvenaria } \\
\text { cantaria } \\
\text { arruamento }\end{array}$ & $\begin{array}{l}\text { - } \\
\text { - coluna } \\
\text { - viga } \\
\text { - parede muro } \\
\text { - revestimento } \\
\text { - piso peitoril } \\
\text { - moldura } \\
\text { - mobiliārio } \\
\text { - escultura } \\
\text { - guia-sargeta } \\
\text { - calçamento } \\
\text { - mourão }\end{array}$ & \\
\hline basa1to & brita & $\begin{array}{r}\text { concreto } \\
\text { pavimentação } \\
\text { enrocamento } \\
\text { filtro }\end{array}$ & - & carga \\
\hline arenito & brita & $\begin{array}{r}\text { agregado } \\
\text { filtro }\end{array}$ & - & $\begin{array}{c}\text { carga } \\
\text { abrasivo } \\
\text { vidro } \\
\text { fundição } \\
\text { refratãrio }\end{array}$ \\
\hline & talhe & $\begin{array}{l}\text { arruamento } \\
\text { alvenaria }\end{array}$ & $\begin{array}{l}\text { - calçamento } \\
\text { - parede-muro }\end{array}$ & \\
\hline ardỏsia & talhe & $\begin{array}{l}\text { alvenaria } \\
\text { mobiliärio }\end{array}$ & $\begin{array}{l}\text { - cobertura } \\
\text { - piso } \\
\text { - tampo de mesa } \\
\text { - quadro negro }\end{array}$ & eletrônica \\
\hline
\end{tabular}


passam por vảrias etapas de processamento (Quadro 5).

A primeira é a prospecção. Ela compreende todas as investigações geológicas do jazimento e da rocha, para definição do local onde implantar a pedreira, em termos de qualidade do material e da situação geogräfica.

A fase subsequente é a industrialização, compreendendo a extração, o desbaste, a serragem e o polimento. Apesar de profundamente diferentes, essas atividades são reunidas numa mesma etapa por fornecerem produtos para a fase seguinte, de comercialização. Após a extração dos blocos, as demais operações são executadas conforme o destino específico das peças. Ao passo que, a produção de alvenaria se completa com o desbaste e modelagem, a produção de cantaria segue até a serragem e polimento. Apesar do alto grau de desenvolvimento tecnológico jả alcançado, os processos de industrialização das pedras são afetados por sérios problemas (YOSHIDA, 1972).

A comercialização reüne atividades de divulgação do material que, depois de conquistado posição competitiva no mercado, estarả em condições de venda. A comercialização compreende o transporte das peças acabadas, das oficinas de beneficiamento (marmorarias), até a obra. o deslocamento das peças exige cuidados especiais que, juntamente com os combustiveis, consistem num importante fator para a composição do preço final do produto e, portanto, da viabilidade da jazida.

A aplicação consta do arranjo e colagem das peças na obra. Trata-se de uma atividade eminentemente artesanal e seu bom resultado depende da beleza e aderência da pedra e da habilidade artística do canteiro.

Pronta a obra, iniciam-se as atividades de conser- 


\begin{tabular}{|c|c|c|c|c|}
\hline & QUADRO 5 - ETAPAS DA PE & ODUÇAO DE MATERIAI & S DE CANTARIA & \\
\hline \multirow{2}{*}{ Fase } & \multirow{2}{*}{ Atividade } & \multicolumn{2}{|c|}{ Produto } & \multirow{2}{*}{ Subproduto } \\
\hline & & Alvenaria & Cantaria & \\
\hline Prospecção & Investigações geológicas & \multicolumn{2}{|c|}{ Pedreira } & $\overline{-}$ \\
\hline \multirow{4}{*}{ Industrialização } & Extração & $\begin{array}{c}\text { Blocos de vários } \\
\text { tamanhos }\end{array}$ & - & Lascas, pedrisco \\
\hline & Desbaste, modelagem & $\begin{array}{l}\text { Peças de várias } \\
\text { formas e tamanhos }\end{array}$ & - & Pedrisco \\
\hline & Serragem & Placas rústicas & & $\begin{array}{l}\text { Cacos, pedrisco,pó } \\
\text { de märmore }\end{array}$ \\
\hline & Polimento & - & Peças polidas & $\begin{array}{l}\text { Cacos, pedrisco, pó } \\
\text { de mármore }\end{array}$ \\
\hline Comercialização & $\begin{array}{c}\text { Propaganda, venda, } \\
\text { transporte }\end{array}$ & $\begin{array}{c}\text { B1ocos e peças } \\
\text { rusticas }\end{array}$ & $\begin{array}{l}\text { Placas e pe- } \\
\text { ças polidas }\end{array}$ & $\begin{array}{l}\text { Cacos, pedrisco,po } \\
\text { de märmore }\end{array}$ \\
\hline Aplicação & Arranjo, colagem & \multicolumn{2}{|c|}{ Obra acabada } & Cacos \\
\hline Conservação & Limpeza, proteção & \multicolumn{2}{|c|}{$\begin{array}{c}\text { Manutenção do lustro, manutenção } \\
\text { da beleza, maior durabilidade da } \\
\text { obra }\end{array}$} & - \\
\hline
\end{tabular}


vação. Sua eficiência depende do cuidado no uso dos

materiais de limpeza e de proteção. Cada tipo de pedra uma modalidade de conservação específica.

exige

Apesar da intima relação de cada uma das etapas de produção das cantarias com a imediatamente anterior, não tem 'havido sua perfeita integração nos empreendimentos, principalmente com a prospecção. Em geral, os blocos são produzidos por pequenos grupos isolados de extratores, numa atividade semelhante ao garimpo (AZAMBUJA \& SILVA, 1977), e vendidos às indústrias de beneficiamento, cujos processos valorizam o produto de $140 \%$ a $420 \%$ (MENDES, 1974). Ta1 concentração de rentabilidade, se por um lado tem favorecido o extraordinário desenvolvimento dos métodos de afeiçoamento da pedra, por outro tem cincido as atividades da fase de apropriação de recursos das atividades das fases de beneficiamento.

0 fato tem causado grandes desníveis tëcnicos e financeiros entre as etapas iniciais e finais do processo dificultando o estabelecimento de um fluxo industrial adequado à demanda. Com índices de expansibilidade praticamente nulos há muitos anos e com baixas produtividades de $2,5 \mathrm{~m}^{3} /$ /homem/mês (MENDES, 1974), a extração de blocos não tem conseguido abastecer as marmorarias que, por vezes, têm sido obrigadas a reduzir o ritmo de trabalho. Não dispondo de materiais em quantidades suficientes para suas obras, os construtores são levados a optar por substitutos, com graves consequências para ambos os setores.

Uma outra feição desse mesmo problema ê a notâvel concentração da divulgação de trabalhos nas atividades de industrialização, aplicação e conservação, enquanto que as atividades de prospecção têm ficado por conta de tratamentos empiricos. Apesar da grande quantidade de periődicos de vârias nacionalidades (Quadro 6) e encontros específicos para cantaria (ROSSI \& TORRACA, 1972 e 1976), quase nada existe 


\begin{tabular}{|c|c|c|}
\hline QUADIRO 6 & - PERIODICOS ESPECIALIZADOS LM MATE & DE CANTARIA \\
\hline PNIS & NOME DO PERLODICO & ENDEREÇO \\
\hline \multirow{3}{*}{ ALEMANHA } & STEINMETZ UND STENBILDIAAUER & $\begin{array}{l}\text { Streitfelstrasse is } \\
\text { Munchen } 8\end{array}$ \\
\hline & DER NATURSTEIN & $\begin{array}{l}\text { Frauentstrasse 77-79 } \\
\text { U1m-Donau }\end{array}$ \\
\hline & DIE NATURSTEIN INDUSTRIE & $\begin{array}{l}\text { Celeitstrasse } 105.605 \\
\text { Affenbach }\end{array}$ \\
\hline BLLGICA & STEEN EN MARMER - PIERRE ET MARBRE & $\begin{array}{l}\text { Galerie du Centre, Bureau } 328 \\
\text { Bruxelles } 1\end{array}$ \\
\hline BKASIL & ROCHAS DE QUALIDADE & $\begin{array}{l}\text { Av.Prestes Maia,241, cj.3520 } \\
\text { 01031-São Paulo, Sp }\end{array}$ \\
\hline ESPANHA & MARMOLES Y GRANITOS & $\begin{array}{l}\text { Mollorca, } 272-274-\text { Tda.1 } \\
\text { Barcelona } 9\end{array}$ \\
\hline \multirow{3}{*}{ ESTADOS UNIDOS } & MONUMENTAL NEWS-REVIEW & $\begin{array}{l}142 \text { W. WASHINGTON St } \\
\text { Bradford - Penna } 16701\end{array}$ \\
\hline & ART IN STONE & $\begin{array}{l}343, \text { Granite Street, Baintre } \\
\text { Mass }\end{array}$ \\
\hline & STONE MAGAZINE & $\begin{array}{l}\text { I100 Waterway Bird Indianopolis } \\
\text { Ind. } 46202\end{array}$ \\
\hline FRANÇA & LE MAUSOLEE & $\begin{array}{l}26, \text { Rue du Molisn B.P.B.69 } \\
\text { Givors }\end{array}$ \\
\hline HOLANDA & NATURSTEEN & $\begin{array}{l}\text { Keizergracht } 11.1 \\
\text { Ansterdam C }\end{array}$ \\
\hline \multirow{3}{*}{ INGLATERRA } & STONE INDUSTRIES & $\begin{array}{l}\text { 54-55. Wilton Road } \\
\text { London S.K.. }\end{array}$ \\
\hline & THE QUARRY MANAGERS & $\begin{array}{l}\text { 62-64 Baker Street } \\
\text { London W.1 }\end{array}$ \\
\hline & INDUSTRIAL DIAMOND REVIEW & $\begin{array}{l}131 \text { Fleet Street } \\
\text { London E.C. } 4\end{array}$ \\
\hline \multirow{6}{*}{ ITKLIA } & MARMI GRANITI PIETRI & $\begin{array}{l}\text { Via Boccaccio } 24 \\
201123-\text { Milano } \\
\end{array}$ \\
\hline & L'INFORMATORE DEL MARMIISTA & $\begin{array}{l}\text { Via del Minatore } 5 / 6 \\
37100 \text { Verona }\end{array}$ \\
\hline & BORSA MARMI & $\begin{array}{l}\text { Via Tolentino } 5 \\
\text { Milano }\end{array}$ \\
\hline & MARMO MACCHINE & $\begin{array}{l}\text { C.P. } 1068 \\
28100-M i 1 \text { ano } \\
\end{array}$ \\
\hline & IL GIORNALE DEL MARMO & $\begin{array}{l}\text { Via Don Minzoni } 27 \\
\text { Gartarn }\end{array}$ \\
\hline & PIETRI & $\begin{array}{l}\text { Via Niz2a } 59 \\
20329 \text { Roma }\end{array}$ \\
\hline SUIÇA & KUNST UND STLIN & $\begin{array}{l}\text { Gacineriweg } 1 \\
8047-2 u r\} \mathrm{ch} \\
\end{array}$ \\
\hline
\end{tabular}

Segundo ROCHAS DE QUALIDADE, maio/junho, 1976, p. 26. 
sobre a avaliação de recursos desses materiais.

Tal comportamento, em relação a esse setor da indústria extrativa mineral, tem sido justificado pela abundância de rochas e pela facilidade de extração na maioria dos países, admitindo-se o atendimento da demanda como certo e garantido, a médio e longo prazo (25 anos). Outra justificativa tem sido a instabilidade da moda, desencorajadora de investimnentos de retorno não imediato. Entre investir no desenvolvimento de um recurso mineral, que pode se tornar ultrapassado a qualquer momento, ou em equipamentos que podem ser utilizados no beneficiamento de qualquer rocha que venha ser preferida, os empresários têm concentrado seus esforços nas atividades de industrialização, (POWER, 1975 ; SHELTON \& DRAKE, 1975; AZAMBUJA \& SILVA, 1977).

Sem apoio e sem incentivos financeiros, profissionais e empresảrios têm preferido os empreendimentos na área dos minerais metảlicos que, além de mais protegidos pelos órgãos governamentais, apresentam maiores impactos econômicos, sociais e desafios técnicos.

Do ponto de vista econômico, os preços de uma tonelada beneficiada $\left(12,5 \mathrm{~m}^{2}\right.$ de placas polidas) com que são oferecidos no mercado cantarias de mármore e de granito,demonstram, quando não sua superioridade, a equiparabilidade aos preços dos minerais metálicos mais valiosos

(UNITED NATIONS, 1976; BRASIL, 1980). Os empreendimentos da ärea das cantarias têm ainda a seu favor os pequenos investimentos em relação aos metảlicos.

Do ponto de vista social, por compreender atividades essencialmente manuais, que não exigem altos níveis de qualificação profissional, a extração da pedra se presta bastante para os programas de tecnologia intermediāria, com a fixação de mão-de-obra alternativa com atividades agríco- 
las (UNITED NATIONS, 1976).

Do ponto de vista tëcnico, os desafios do setor das cantarias não são menores do que as demais indüstrias extrativas minerais. Se os recursos em rochas para construção são inesgotảveis, a ponto de justificar a desnecessidade de pesquisas geológicas (POWER, 1975; SHELTON \& DRAKE, 1975), seu aproveitamento é limitado por uma série de fatores econômicos e geogräficos. Com a expansão dos centros urbanos, da demanda de materiais de construção e com o aumento dos preços do transporte, tem sido cada vez mais necessária a retomada de pedreiras abandonadas e o desenvolvimento de novas fontes, mais próximas e mais rentāveis. E a extração de pedras para construção tem outro argumento a seu favor; quando bem planejada, é das atividades que menos afetam a ecologia, dado o caráter restrito de seu desmonte e o elevado grau de seu aproveitamento, sem acủmulo de rejeitos inüteis e poluentes (UNITED NATIONS, 1976).

Essas opiniões de värios autores mostram que os impactos econômicos e sociais e os desafios técnicos dos empreendimentos da ảrea dos metâlicos são apenas aparentemente maiores do que os da ärea das cantarias, não se justificando a desatenção para com elas.

Enquanto tem perdurado essa mentalidade o aproveitamento dos recursos em rochas para cantaria têm ficado a cargo de aventureiros, sem condições técnicas e econômicas de uma exploração racional. Quase sempre constituindo micro explotações de cunho anárquico, os mineradores têm atuado de maneira errätica, intermitente e improvisada, através de métodos rudimentares. Assim, sem nenhuma orientação tëcnica, muitas pedreiras têm sido abertas ao acaso e abandonadas pouco depois, por terem se tornado antieconômicas, frente aos problemas relativos, principalmente, à geologia dos jazimentos. O fato tem ocorrido mesmo na Itảiia, França e Portugal, 
os maiores produtores mundiais de cantarias (SHELTON \& DRAKE, 1975). Em Portuga1, por exemplo, a quantidade de pedreiras abandonadas chega a perfazer $80 \%$ das existentes (LADEIRA, 1977 ) .

Quanto às vantagens ou desvantagens da constituição de empresas que se encarreguem de todas as atividades de produção de cantarias, ou de empresas que se dediquem a atividades específicas da produção de cantarias, não hả grande concordância entre os técnicos do setor (CAVALCANTI, 1951; CURRIER, 1960; MENDES,1974 e 1979A; POWER,1975).

A coexistência de produtores autônomos de blocos, de um lado, e de beneficiadores, de outro, parece ser pacífica. Ela tem proporcionado ganhos mensais acima dos pisos salarais aos primeiros e tem proporcionado matéria-prima a preços mais baixos, caso a extração ficasse a seu cargo, aos segundos (AZAMBUJA \& SILVA, 1977).

As opiniões são unânimes, entretanto, quanto à necessidade de maior atenção às atividades de prospecção, para minimizar os desníveis entre as vārias fases do processo de produção das cantarias. Igualmente unânimes são as opiniões dos têcnicos quanto à necessidade de maior controle do setor, para melhor planejamento e maior facilidade de atuação na ārea.

\section{4 - Qualificação das Rochas para Cantaria}

As rochas são o unico material encontrado pronto na natureza, que confere solidez, durabilidade, requinte e beleza às construções. A rigor toda rocha tem alguma aplicação na construção civil, porêm o bom proveito de suas qualidades depende da adequação, a cada finalidade desejada. 
A qualidade das rochas para construção baseia-se no princípio de que todo material, quando submetido à condições diferentes daquelas em que foi formado, sofre transformações para readquirir o equilíbrio físico-químico no novo ambiente. Assim, uma rocha será tanto melhor quanto mais estảve1, nas condições de uso.

A estabilidade das rochas, em dadas condições depende, primeiro, dos agentes que atuaram em sua formação e, em segundo, dos agentes do novo ambiente em que se encontrarem. Para as cantarias, ela corresponde à resistência aos agentes a que ficarão sujeitas apōs sua aplicação nas construções.

Tanto os agentes de formação, como os de transformação das rochas são analisados quanto à temperatura,pressão e quimismo. Na formação, eles são responsảveis pela natureza física e quỉmica da rocha e, na transformação, eles são responsảveis pela estabilidade física e química da mesma.

Dependendo da intensidade da temperatura, pressão e quimismo na formação dos materiais da crosta, são reconhecidos os três tipos de rochas (îgneas, sedimentares, metamörficas), que se transformam uns nos outros, conforme as mudanças nas condições reinantes. Eles são distintos, entre si, pelas naturezas físicas e químicas e pelos modos de ocorrências, com diferentes propriedades para a construção civil.

As características físicas das rochas são expressas em termos de textura e estrutura.

A textura das rochas diz respeito ao inter-relacionamento de seus grãos minerais, observada em amostras de mão, ou ao microscópio (WILLIAMS, TURNER \& GILBERT, 1970). Ela compreende a forma (granulares ou alongados), tamanho 
(grandes ou pequenos), disposição (orientados ou não-orientados), intercrescimento (imbricados ou justapostos). Integrando todas essas feições, a textura traduz a natureza da rocha quanto à cristalinidade (cristalina ou aglomerătica), granulação (fina ou grosseira), coesividade (friāvel ou consolidada), porosidade (porosa ou compacta).

A granulação é usada como critërio de classificação dos märmores (ERGUVANLI, YUZZR, GULLEÇ \& ZANBAK, 1974) e de outras rochas de construção. Correlacionada às demais feições texturais, são usadas denominações especiais para a cristalinidade das rochas, como "textura granitóide" para as ígneas, "textura cristaloblástica" para as metamórficas, "textura sacaröide" para as sedimentares.

A coesividade depende do grau de cristalinidade, da uniformidade granulométrica e da compacidade, refletindo a capacidade da rocha suportar os esforços desenvolvidos sobre os vários elementos das construções.

A porosidade, ou volume de vazios - v, influi em outras propriedades físicas das rochas, como na compacidade, densidade, resistência mecânica e alterabilidade, na razão inversa de seus valores. Ela é calculada segundo a fórmula:

$$
v=\frac{P_{e}-P_{S}}{V} \cdot 100 \%
$$

onde $\mathrm{P}_{\mathrm{e}} \overrightarrow{\mathrm{e}}$ o peso da amostra encharcada; $\mathrm{P}_{\mathrm{S}} \overrightarrow{\mathrm{e}}$ o peso da amostra seca; $V$ é o volume total da amostra. A porosidade depende tambëm, da forma e tamanho dos espaços (CURRIER, 1960).

Segundo WINKLER (1975), não existe rocha totalmente compacta, e a dimensão e morfologia dos vazios refletem sua origem ígnea, sedimentar ou metamórfica. 
Quanto ao tamanho, baseando-se em trabalhos

de Russe1 e de Brady, CAVALCANTI (1951) quantificou a porosidade das rochas, concluindo que "quanto menores forem seus poros, menores serão seus elementos sölidos" e "para um mesmo volume de poros, a superfície dos elementos sölidos, ao redor de cada cavidade, serả aumentada de duas vezes para cada redução de metade do diâmetro dos poros". Russe1 (CAVALCANTI, 1951) divide os espaços vazios das rochas em microporos (menores que $0,005 \mathrm{~mm}$ ) e macroporos (maiores que $0,005 \mathrm{~mm})$. Para Choquette \& Pray, os megaporos têm diâmetros entre $256 \mathrm{~mm}$ e $0,062 \mathrm{~mm}$ e, para Vos, os macrocapilares têm diâmetros entre $0,062 \mathrm{~mm}$ e $0,0001 \mathrm{~mm}$ e os microcapilares menores que 0,0001 mm (WINKLER, 1975). Quanto maior for a microporosidade de uma rocha, tanto menos ela será indicada para cantaria.

A porosidade está relacionada com outras propriedades físicas das rochas chamadas absorção e adsorção. Apesar das diferenças conceituais, segundo WINKLER (1975), elas são reunidas sob a designação ünica de "sorption".A "sorção" de uma rocha ê calculada pela mesma fórmula da porosidade, porẻm, antes da pesagem à seco a amostra levada à $105^{\circ} \mathrm{C}$, por 24 horas, e antes da pesagem à molhado é imersa em ảgua destilada à $20^{\circ} \mathrm{C}$, por 48 horas.

Segundo a bibliografia citada por CURRIER (1960), a preocupação com essa feição petrogräfica vem desde 1926 , com os trabalhos de Kessler que serviram para o estabelecimento de norma do United States Bureau of Standards Technology. Segundo YOSHIDA (1972), na França, os principais estudos na ärea foram desenvolvidos por Thenỏz, na década de sessenta.

Para cantaria, as rochas devem ser consolidadas, com altas coesividades e porosidades mínimas, isto ẻ, as rochas devem exibir altos graus de cristalinidade, podendo ser 
finas ou grosseiras, orientadas ou não, imbricadas ou cimentadas.

Por estrutura são compreendidas feições maiores das rochas, que envolvem grupos de minerais, em geral observäveis somente no campo (WILLIAMS, TURNER \& GILBERT, 1970). Uma estrutura pode ser primäria, quando 1igada à pröpria origem da rocha, como bandas, xistosidade, dobras, acamamento, vesículas, ou pode ser secundäria, quando resultante de fenômenos geológicos posteriores à sua formação, como fissuras, fraturas, veios, dissoluções, amígdalas. Todas elas representam descontinuidades, nem sempre visiveis, mas que se manifestam negativamente no desempenho da rocha na construção.

As estruturas, juntamente com feições texturais, influi, na coesividade das rochas, tornando-as menos resistentes aos esforços mecânicos. ERGUVANLI, YÜZER, GUlleÇ \& ZANBAK (1974) denominam a propriedade de "anisotropia mecânica", quantificando-na atravês da equação:

$$
A M=\frac{K_{\max }-K_{\min }}{K_{\text {med }}}
$$

em que $A M$ è o coeficiente de anisotropia mecânica; $K_{\max }$ é o número de rupturas māximo, na direção em que ocorre o maior número de rupturas; $K_{\text {min }} \vec{e}$ o numero de rupturas mínimo, na direção em que ocorre o menor nümero de rupturas; e $K_{m e d} \vec{e} a$ mêdia de rupturas em todas as direções.

Alëm de critërio para classificação dos märmores (ERGUVANLI, YUZZER, GULLC \& ZANBAK, 1974), o coeficiente de anisotropia mecânica $\vec{e}$ importante para orientação no desmonte de blocos.

Para a qualificação das rochas, quanto à resistência mecânica, são consideradas a resistência à compressão, 
tração e flexão, regidas pelo coeficiente de elasticidade (WINKLER, 1975).

Para aplicação na construção civil é preciso que as rochas sejam compactas e uniformes. Mas, para alvenaria e cantaria, è desejảvel que elas apresentem tendências à ruptura em direções predeterminadas no maciço, para facilidade de extração e talhe. Porẻm, descontinuidades com espaçamentos inferiores às dimensões ötimas dos blocos para\% os teares $(1 \mathrm{~m} \times 2 \mathrm{~m} \times 3 \mathrm{~m})$, prejudicam seu aproveitamento. Para cantaria, ainda, certas estruturas, como bandas, dobras, veios, podem aumentar o valor decorativo da rocha através dos desenhos exóticos que podem formar.

As caracteristicas quimicas das rochas compreendem aspectos de sua composição mineral. Elas são importantes para a previsão do comportamento da rocha, nos ambientes em que for utilizada, conhecido por "alterabilidade", ou"durabilidade" (CURRIER, 1960).

Segundo CAVALCANTI (1951), parece ter sido Pieri, em 1941, quem primeiro se preocupou com essa feição, começando por dividir as rochas em silicâticas e carbonäticas, distintas, entre si, pela maior, ou menor, resistência aos âcidos.

Quanto à mineralogia, as rochas para cantaria são amplamente variảveis (Quadro 2). Por compreenderem minerais altamente instáveis, nem sempre reconhecíveis a olho nü, CAVALCANTI (1951), YOSHIDA (1972), CARUSO, TAIOLI \& FARJALLAT (1978)' recomendam estudos petrogräficos rigorosos para a identificação e quantificação mineralögica antes da utilização da rocha.

Outra feição das rochas, dependente da composição mineral, é a cor. Ela è importante para fins decorativos (CURRIER, 1960; WINKLER, 1975). 
Enquanto que a cor de uma rocha è determinada pe1 a cor do mineral predominante, sua uniformidade depende da granulação e distribuição do mineral que a determina. Sua constância depende da estabilidade química desses minerais.

Em 1921, Backheuser (CAVALCANTI, 1951) identificou os minerais ferrosos (pirita, marcassita, pirrotita, biotita, granada) como os mais impróprios para a manutenção da cor, principalmente, quando a rocha ê utilizada em exteriores, devido à sua fảcil oxidação e tingimento de ferrugem.

A cor das rochas varia, tambëm, com a porosidade e a rugosidade da superfície, por reterem umidade, favorecendo o desenvolvimento de microorganismos.

Para cantaria, a cor condiciona tanto o preço das peças, como sua aplicação em interiores ou exteriores. Rochas de cores firmes, homogêneas, e pouco comuns alcançam preços extraordinärios, porém, rochas de cores exöticas, de alto valor decorativo, mas instáveis, só podem ser usadas em interiores.

Para efeito de aplicação na construção, as características físicas e químicas das rochas são designadas "propriedades tecnológicas". Elas são expressas por valores numéricos chamados "especificações" que aprovam, ou desaconselham, o material para a finalidade desejada, em termos de sua trabalhabilidade e durabilidade. As especificações são determinadas em laboratório através de ensaios padronizados pela engenharia (BOWLES, 1939; MENDES, 1974, 1979A; WINKLER, 1975 ).

A trabalhabilidade compreende a maior ou menor facilidade de extração, desdobramento e aderência da rocha.

A extração e o desdobramento (Quadro 5) abrangem 
os processos de divisão da rocha em blocos, a partir do maciço rochoso, atê a produção de peças acabadas, com formas e tamanhos adequados a cada finalidade.

Dessa forma, a trabalhabilidade depende, no primeiro estägio de produção da cantaria, da facilidade com que a rocha ê rompida. Seu rompimento deve se dar segundo direções ortogonais, predeterminadas, produzindo blocos prismáticos, mais ou menos uniformes, donde a conveniência de descontinuidades citada atrảs. A trabalhabilidade ê função da anisotropia mecânica da rocha no maciço, e as superfícies de ruptura podem ser planas ou conchoidais, e lisas ou äsperas. Em gera1, rochas homogêneas e grosseiras apresentam superfícies de ruptura planas e äsperas, enquanto que rochas finas se rompem em superfícies conchoidais e 1isas.

No segundo estảgio de produção das cantarias, a trabalhabilidade depende da dureza da rocha. Ela corresponde à mêdia das durezas dos minerais presentes em cada direção da superfície da rocha (CURRIER, 1960) e depende da textura (cristalịna ou aglomerática). Esse conceito è vâlido, inclusive, para as rochas uniminerälicas. Sendo a dureza dos minerais uma propriedade anisotrópica, a dureza das rochas serâ a mêdia das durezas nas värias direções em que cada exemplar do mineral for cortado.

Não existem testes padrões para a determinação da dureza das rochas, sendo avaliada em termos de resistência à penetração, à abrasão (CURRIER, 1960), ou ao impacto (WINKLER, 1975). Para qualificação da rocha para cantaria, apenas a segunda é fundamental.

CAVALCANTI (1951) denominou as rochas, quanto à dureza, de:

- brandas, quando puderem ser cortadas facilmente 
com serra de dentes, como o esteatito, o argilito, etc.;

- semiduras, quando forem dificilmente cortadas por serra de dentes, mas o forem facilmente por serra 1 isa com abrasivos, como os calcários, os arenitos, etc.;

- duras, quando forem cortadas, somente, por serra lisa com abrasivos, como os mármores;

- duríssimas, quando forem dificilmente cortadas por serra lisa com abrasivos, mas o forem facilmente por serra de diamante, ou carborundum, como os granitos.

A dureza das rochas para cantaria é expressa, tambẻm, em termos de resistência ao desgaste, ou à abrasão (BOWLES, 1939), principalmente quando as peças se destinam à pisos. Alêm de depender da composição mineral, a abrasividade das cantarias depende do grau de cristalização, da granulação e de homogeneidade granulométrica da rocha. Em geral, rochas cristalinas, finas e homogêneas, são mais duras que rochas aglomeräticas, grosseiras e orientadas.

A dureza, ou a abrasividade, das rochas ê um importante fator para a composição do custo da cantaria nomercado, em vista da proporcionalidade com o desgaste das ferramentas e o tempo de preparo das peças.

A aderência corresponde à facilidade e eficiência da colagem das peças na obra. Ela depende da interação química e física da superfície da rocha com os ligantes. E avaliada pelo esforço de tração, por unidade de superfície, necessário para a separação das partes envolvidas. Essa propriedade depende da natureza mineralögica e do tipo de superfície da pedra a ser assentada. Em geral, rochas grosseiras, com superfícies ảsperas, apresentam maiores aderências que rochas finas, com superfícies lisas. Para o 
perfeito assentamento, o ANUARIO INDUSTRIAL BRASILEIRO DE MARMORES E GRANITOS (1973/1974) recomenda que as peças devem ser previamente molhadas e a argamassa deve ter composição específica, de acordo com a natureza da rocha. Para granitos, o ligante deve ter saibro comum, areia e cimento, na proporção $3: 1: 1$ e, para märmores brancos, cal, areia e cimento na proporção $2: 2: 1$. Para CAVALCANTI (1951)entretanto, a argamassa para granito deve conter os mesmos componentes na proporção $2: 3: 1$.

A durabilidade de uma rocha indica o tempo que a cantaria permanecerá na construção sem sinais de deteorização e depende da composição mineral e dos agentes do meio.

Os agentes do meio correspondem às intempéries e aos materiais de limpeza, em decorrência dos quais as rochas começam perder a cor, o brilho e a coesividade, atë o esfacelamento total.

Dos agentes físicos do intemperismo, o mais enērgico ê a variação de temperatura. Com relação ao comportamento tërmico das rochas para cantaria, são considerados a condutividade e o calor específico.

Ta1 como a dureza, a condutividade térmica é anisotrópica. Num mineral ela varia de uma direção para outra, e, numa rocha, de um mineral para outro, provocando esforços multidirecionais pelas incessantes dilatações e contrações diurnas e noturnas. Em 1948, Rinne (CAVALCANTI, 1951) calculou que a pressão exercida pela cristalização da água é da ordem de $146 \mathrm{Kg} / \mathrm{cm}^{2}$. O fenômeno è conhecido por "gelividade" e ocorre mesmo em rochas quase secas, por quedas bruscas da temperatura.

Os agentes químicos do intemperismo atuam, principalmente pela atividade äcida da atmosfera, dos organismos,e 
dos produtos de limpeza, promovendo a dissolução e a oxidação dos minerais (WINKLER, 1975). As rochas mais apropriadas para cantaria são as mais resistentes à esses agentes. São as mais ricas em minerais óxidos e as menos porosas. Ainda, uma cantaria serā tanto mais durāvel quanto mais 1 isa e polida tiver sido sua superfície.

o comportamento das rochas para construção aos agentes quimicos do intemperismo e denominado "alterabilidade", ou "resistência ao intemperismo". Ele e usado por ERGUVANLT, YÜZER, GÜLEÇ \& ZANBAK (1974) como critërio de classificação dos märmores. Umedecendo amostras de rochas com soluções cem mil vezes mais concentradas que as äguas das chuvas, e secando-nas a $105^{\circ} \mathrm{C}$, em ciclos de 8 horas, durante 30 dias, eles propuseram um esquema para quantificação da resistência ao intemperismo - RI - atravês da equação:

$$
R I=\frac{a_{n}-a_{0}}{a_{o}}
$$

em que $a_{n}$ è a absorção após $n$ ciclos e $a_{0} \vec{e}$ a absorção da rocha sä.

Segundo WINKLER (1975), foram Archibal Geykie, em 1880, na Inglaterra, e A.A. Julien, em 1884, nos Estados Unidos, os primeiros a procurar quantificar o intemperismo sobre rochas na construção. Mas foi somente após a Segunda Guerra que os estudos alcançaram nivel de monta. Segundo as referências bibliogräficas de CAVALCANTI (1951), CURRIER (1960), YOSHIDA (1972) e WINKLER (1975) existe grande nümero de pesquisadores trabalhando nessa ärea, em värios países. No Brasil, são dignos de menção os estudos de José Eduardo Siqueira Farjallat e Luiz Geraldo Caruso, no Instituto de Pesquisas Tecnológicas do Estado de São Paulo S.A. -
IPT. 
A adequabilidade das rochas para construção depende ainda, da capacidade de suportarem os esforços mecânicos a que ficarão sujeitas. Ela é avaliada em termos de resistência à abrasão, compressão, flexão e tração. A correlação de värias feições texturais, estruturais e composicionais das rochas, com os värios tipos de solicitações mecânicas, mostra grandes semelhanças nas proporcionalidades, o que permite as seguintes correlações:

- rochas com alta abrasividade, em geral tem elevados mödulos de ruptura;

- rochas de granulação fina e homogênea são mais resistentes aos esforços mecânicos, que as grosseiras e heterogêneas. CAVALCANTI (1951) explica que isso ocorre porque os esforços sobre rochas de granulação fina, por serem mais densas, são distribuídos uniformemente entre os grãos vizinhos, ampliando os limites de equilibrio e, consequentemente, aumentando a resistência à ruptura;

- rochas não-orientadas são mais resistentes aos esforços mecânicos que as orientadas. CAVALCANTI (1951) explica que isso ocorre porque a orientação reflete direções preferenciais de cristalização, ao longo da qual o intercrescimento dos minerais $\vec{e}$ menor, e, portanto, menor a resistência aos esforços;

- a resistência mecânica das rochas decresce com - aumento da porosidade, do fissuramento e do grau de umidade. Assim, quanto menos porosa e fissurada, mais compacta $\ddot{e}$ a rocha. A porosidade e o fissuramento tambëm controlam a densidade de maneira que, rochas granulométricas e mineralogicamente homogêneas têm resistências crescentes com a densidade.

Em 1923, Mesnager (CAVALCANTI, 1951) estabeleceu 
a correspondência entre a resistência à compressão - RC, em $\mathrm{Kg} / \mathrm{cm}^{2}$, e a densidade aparente - DA, em $\mathrm{Kg} / \mathrm{cm}^{3}$, de rochas calcārias, tendo chegado à equação:

$$
\mathrm{RC}=150 \frac{\mathrm{DA}-0,83}{2,82-\mathrm{DA}}
$$

Entretanto, em 1946, Boucart (CAVALCANTI, 1951) concluiu que os valores obtidos com essa fórmula correspondem ao limite superior da solicitação e propôs, para câlculo do limite inferior, a equação:

$$
\log \mathrm{RC}=1,24 \mathrm{DA}-0,25
$$

Para cantaria, alem das qualidades gerais descritas para a construção, as rochas devem apresentar beleza estētica e suscetibilidade ao polimento.

A beleza estëtica de uma rocha encerra muita subjetividade, em função de gostos individuais, influenciados pela moda. Compreende feições relativas à cor, textura e estrutura, cujas combinações permitem obter variados efeitos decorativos.

A suscetibilidade ao polimento de uma rocha $\overrightarrow{\mathrm{e}}$ a capacidade de se deixar lustrar, sem desagregar, adquirindo superfícies lisas e refletivas. Essa propriedade $\vec{e}$ importante por realçar a cor dos minerais e dos desenhos texturais e estruturais da rocha, e reduzir a absorçao tërmica e 1 iquida da rocha, contribuindo para sua durabilidade, facilita a limpeza e conservação das peças.

Para TOURENQ (1974) $\vec{e}$ impossivel caracterizar tecnologicamente as rochas para construção sem considerar os aspectos geolögicos dos jazimentos. Entretanto YOSHIDA (1972) 
aponta o ainda pequeno conhecimento da interdependência entre a natureza petrológica, as propriedades tecnolögicas e os efeitos das solicitações naturais e artificiais. Para YOSHIDA, a falta de padronização na execução e expressão dos resultados dos ensaios, $\vec{e}$ dos maiores problemas do setor.

\section{5 - 0 Uso das Rochas na Construção}

Juntamente com a madeira e as peles de animais, a pedra foi dos primeiros materiais a ser utilizado pelo homem. Ao conträrio dos demais, os objetos em pedra sobrePedra aos primördios da humanidade.

Inicialmente, a pedra foi utilizada como pequenos utensilios rústicos (Período Paleolítico = Pedra Lascada) e depois como grandes blocos semi-trabalhados (Periodo Neolitico = Pedra Polida). Não existe grande concordância entre os estudiosos há quanto tempo ocorreram e quanto tempo duraram esses períodos prë-históricos. Sabe-se que eles foram bastante heterogêneos geograficamente, o que tem dificultado as correlações e datações. Para MOORE (1958), o Neolítico teve inîcio na Amërica do Norte hä 10.000 anos, mas Giampera (SALVAT, 1979) cita que datações radiomëtricas de lascas e nódulos da Europa, atravês do carbono 14, acusam 30,35 e ate 40.000 anos para o mesmo. Daí se conclui que, enquanto na América se vivia no Paleolitico Inferior, na Europa e na Asia jâ se vivia no paleolitico Superior.

Conforme o tamanho, forma e disposição dos elementos líticos, as construções dessa êpoca são denominadas dólmen, menir, megälito, monólito. Calcula-se que existam 50.000 delas ao redor de todo o mundo. As mais famosas são Stonehenge, na Inglaterra, e Carnac, na França. Os mëtodos pelos quais e os objetivos para os quais eram construídas con- 
tinuam inexplicados, mas a grandiosidade das ruinas atestam - fascínio que a pedra exerceu sobre o homem, desde o prin-
cípio da civilização.

Na Europa, o grande ciclo megalitico foi encerrado, em $1500 \mathrm{AC}$, com a descoberta dos metais. Com o advento desses novos materiais, ao conträrio do que se poderia esperar, a pedra se firmou ainda mais como material de construção. Os utensílios metālicos facilitarm seu afeiçoamento, fazendo surgir a arte litica. Ela teve seus maiores impulsos entre os povos que habitaram regiões de farta disponibilidade de pedra, pela sua, desde então, reconhecida maior durabilidade em relação aos demais materiais. Dos tipos 1itológicos mais utilizados pelas civilizaçōes antigas destacam-se o arenito, o granito, o calcärio. Apesar do märmore ter sido usado por civilizações mais antigas da Asia Menor (ERGUVANLI, YÜZER, GULEC \& ZANBAK, 1974), ele só adquiriu fama com os romanos, com a rocha de Carrara.

Os romanos souberam assimilar muito bem a arte em pedra, contribuindo para a arquitetura com a invenção do arco. Antes dele as construções dispunham somente de vigas monoliticas que não permitiam mais que pequenos vãos, em vista da dificuldade em executar o corte e o transporte de blocos longos e pesados. Num arco, os elementos são pequenos e o equilïbrio depende de sua disposição nas colunas e no fecho central (CAVALCANTI, 1951).

Durante a Idade Mëdia, as construções em pedra são representadas, principalmente, pelas catedrais, pontes e castelos, espalhados por toda Europa e Asia.

At $\vec{e}$ o século passado, a manuseabilidade da pedra condicionou a arquitetura, constituindo uma atividade tradicional, mantida entre familias, que a transmitiam de pai 
para filho. Porēm, a histōria da utilização da pedra

na construção não é feita só de arte. Com o aumento de sua demanda nos tempos modernos, nasceu a indústria da pedra. Os maiores progressos nessa ärea tambëm ocorreram nos países de maiores disponibilidades em rochas de qualidade.

Das maiores contribuições para a industrialização da pedra foram as especificações. Na Europa, a normalização dos materiais rochosos para a construção nasceu com a reconstrução de Lisboa, depois do trägico terremoto de 1755. Para MENDES (1974) tal normalização representou a passagem da fase puramente artesanal para a fase industrial da pedra. O maior avanço nesse campo, entretanto, deu-se a partir de 1920 (CAVALCANTI, 1951), com o surgimento das instituições de normas e da divulgação sistemática dos resultados das investigações, em grande nümero de países (Quadro 6).

Apesar do pioneirismo na normalização dos materiais, as primeiras publicações sobre trabalhos de qualificação das cantarias apareceram na Itâlia, em 1892, de autoria de Salmoiraghi (CAVALCANTI, 1951, MENDES, 1974). Na Europa, a Itảlia tem se mantido na dianteira da tecnologia de rochas, secundada pela França e Portugal. Dentre os trabalhos recentes estão "Il Marmo", de Antonio Consiglio, com tiragens datadas de 1949 (CAVALCANTI, 1951) e de 1964, como citada em outra importante obra "A Techinal Guide to the Rational Use of Marble", publicada pela Indüstria de Märmore Italiana em 1972. Ainda na Itảlia, o Centro per 1a Conservazione delle Sculture all'Aperto, de Bologna, tem promovido encontros para tratar, especificamente, da conservação da pedra (ROSSI-MANARESI \& TORRACA, 1972; ROSSIMANARES I , 1976).

$\mathrm{Na}$ França, os trabalhos tecnolögicos das rochas começaram com Monte1, em 1920 (CAVALCANTI, 1951; YOSHIDA, 1972). 
Nas Amëricas, a liderança é exercida pelos Estados Unidos. As primeiras publicações apareceram em 1884 (BOWLES, 1939; CAVALCANTI, 1951; CURRIER, 1960). As atividades têm sido integradas por vảrias instituições de normas, desde 1917 (YOSHIDA, 1972), como a American Society for Testing \& Materials - ASTM, a United States Buildings Institut - USBI, o United States of Mines - USBM, o Marble Institut of America - MIA.

No Brasil, as primeiras construções em alvenaria datam do período colonial (AZAMBUJA \& SILVA, 1977). São construções simples, com blocos irregulares 1igados com argamassa. As primeiras indústrias de beneficiamento de pedra foram instaladas no século passado com a vinda dos imigrantes italianos e portugueses. Durante muito tempo, deu-se preferência aos mârmores estrangeiros, época em que a utilização das cantarias era privilëgio de poucos. Com a descoberta de jazidas de rochas, com qualidades iguais ou superiores às das estrangeiras, a situação foi invertida (Quadro 10 , Figura 3), permitindo ampla difusão do material.Pesquisas de mercado recentes (PIAUI, 1976), entretanto, mostram desconhecimento das cantarias pelos consumidores que têm preferido outros produtos, menos durảveis, menos belos, de preços por vezes superiores, julgando estarem acertando em qualidade e economicidade de suas obras.

No Brasil, o controle têcnico e científico sistemático do preparo e utilização das pedras de construção foi iniciado com a criação dos Cursos de Engenharia Civil, principalmente na Escola Politêcnica, em São Paulo, e na Escola Nacional de Engenharia, no Rio de Janeiro (CAVALCANTI, 1951). Os trabalhos pioneiros são de Backheuser e de Silva,em 1921 , publicados pela "Revista Brasileira de Engenharia" e pela "Revista Didätica da Escola Politécnica".

A normalização dos materiais começou em 1940, no Instituto de Pesquisas Tecnológicas do Estado de São Paulo 
S.A. - IPT, na Associação Brasileira de Normas Técnicas ABNT e no Departamento Nacional de Estradas de Rodagem DNER, cada um com sua publicação periödica. Na década de 1940, foram inauguradas, tambëm as edições da "Revista de Materiais de Construção" e da "Revista DER".

A partir de então têm sido realizados inümeros trabalhos na ärea da tecnologia de rochas, como "Tecnologia da Pedra" (CAVALCANTI, 1951), "Contribuição ao Conhecimento de Características Tecnológicas de Materiais Rochosos" (YOSHIDA, 1972), "Perfil Analitico dos Märmores e Granîtos" (AZAMBUJA \& SILVA, 1977), "Märmores e Granitos Brasileiros" (CARUSO, TAIOLLI \& FAJALLAT, 1978), e editadas revistas especializadas, como "SIMAGRAM - Märmores e Granitos em Revista", "Granitos e Märmores Brasileiros", "Rochas de Qualidade". Dessas revistas apenas a "Rochas de Qualidade" tem sido editada bimensalmente.

$\mathrm{Na}$ ärea da geologia e desenvolvimento de recursos em rochas para construção, tanto em nível nacional quanto internacional, pouco existe a destacar. A maior parte dos dados aparecem como referências complementares de trabalhos sobre qualificação das rochas (CAVALCANTI, 1951, MENDES, 1974 ; POWER, 1975 ; SHELTON \& DRAKE, 1975; AZAMBUJA \& SILVA, 1977).

Dos trabalhos específicos, na ärea internacional, destaca-se o "Geologic Appraisal of Dimension-Stone Deposits" (CURRIER, 1960). De suas citações bibliogräficas, o trabatho mais antigo parece ser o do inglês Howe, em 1910, não encontrado nas bibliotecas de são Paulo.

No Brasi1, não existe nada mais que o "PROJETO NORMA- Reconhecimento e Amostragem para Fins de Caracterização das Ocorrências de Rochas", da ABNT (CAVALCANTI, 1951), e o "Pedra, Pedregulho e Areia: Localização e Estudo" (PICHLER,
1951). 
Não obstante o pequeno apoio tecnolögico recebido, as rochas ocupam posição de destaque, dentre as matérias primas minerais, na maioria dos países. Na Inglaterra, por exemplo, conhecida como produtora de carvão, o volume de rocha para construção produzido é o dobro do desse combustive1 (UNITED NATIONS, 1976). Nos Estados Unidos, a produção de rochas para construção ê a maior indüstria extrativa mineral não-metälica (SHELTON \& DRAKE, 1975).

A partir de 1900 , com o desenvolvimento das estruturas metälicas, do concreto simples e armado, dos agregados leves, das cerâmicas, do vidro, e com a necessidade de construções mais baratas e execução mais räpida, a utilização da pedra de talhe tem sofrido uma queda em relação à brita. Com o concreto, nasceu a arquitetura moderna e a moda do concreto aparente, voltando as vigas retilineas dos gregos e libertando das limitações do arco romano.

Pelo menos nos Estados Unidos, onde se dispõe de dados mais completos, o volume de pedra de talhe utilizado no começo do sēculo perfazia mais da metade da pedra produzida. Porém, em 1974, ela significou menos de 0,2\%, tendo havido, mesmo, redução no nümero de pedreiras e de marmorarias (SHELTON \& DRAKE, 1976). A queda na demanda de pedra de talhe tem sido de $1,7 \%$ ao ano, desde 1954, enquanto que o aumento na demanda de brita foi de $5 \%$. A utilização de rochas na construção tem ficado restrita a alvenarias e cantarias em poucas e pequenas partes dos edifícios.

Apesar. de conquistada boa parte do mercado, os substitutos sintëticos atestam a nobreza das rochas, tentando imitar suas feições decorativas. Graças a isso, SHELTON $\xi$ DRAKE (1975) esperam aumentos de $1,0 \%$ a $2,0 \%$ ao ano, na demanda mundial de pedra de talhe, enquanto que o esperado para a brita é de $3,5 \%$ a $5,0 \%$, até o ano 2.000 . 
No Brasil, a compilação dos dados sobre o setor das pedras de construção tem ficado a cargo do Departamento Nacional da Produção Mineral - DNPM, órgão do Governo Federal, ligado ao Ministërio das Minas e Energia - MME. O DNPM tem divulgado os dados obtidos a partir de 1972, com retroação at $\vec{e} 1960$, atravês das edições do Anuärio Mineral Brasileiro (BRASIL, 1972 a 1980).

Para a interpretação dos dados $\vec{e}$ preciso ter em mente as mudanças introduzidas na sistemática de sua compilação e apresentação, de uma edição para outra. No Quadro 7 são apresentados os bens minerais indexados nas värias edições do Anuãrio, que tem aplicação na construção, confor: me a classificação dos Quadros 2, 3 e 4.

A partir de 1976, incluindo novos tipos Iitolögicos, o Anuário passou a apresentar dados sobre o basalto, gnaisse, granito, märmore e sodalita, reunidos sob a designação de pedras britadas e ornamentais, denominação essa usada nas edições de 1973 e 1975, exclusivamente, para o granito. A não inclusão dos calcärios e do esteatito, nesse grupo de rochas, ê aceitāvel, pois a maior parte de suas produções são destinadas a outros fins. Porëm, é incompreensível a não inclusão das ardósias, dos quartzitos e dos xistos, sabidamente destinados à construção.

Nenhuma edição do Anuärio especifica os destinos de cada parcela da produção dos tipos de rocha considerados. Isso tem dificultado a realização de diagnósticos e prognósticos sobre o setor, principalmente no que se refere a pedras de talhe (ailvenaria e cantaria) e brita.

$\mathrm{Na}$ edição de 1980 as reservas dos värios tipos de rochas do grupo das pedras britadas e ornamentais são apresentados em $\mathrm{m}^{3}$ e não mais em toneladas. 


\begin{tabular}{|c|c|c|c|c|c|c|c|c|c|}
\hline \multicolumn{10}{|c|}{$\begin{array}{l}\text { QUADRO } 7-\text { TIPOS DE ROCHAS CONSIDERADOS } \\
\text { ROcha } \\
\text { RO QUE TEM }\end{array}$} \\
\hline Rocha & 1972 & 1973 & 1974 & 1975 & 1976 & 1977 & 1978 & 1979 & 1980 \\
\hline Ardósia & $x$ & $\mathrm{X}$ & $x$ & $\mathrm{X}$ & $x$ & $x$ & $x$ & $x$ & $\mathrm{x}$ \\
\hline Basalto & & & & & $X(2)$ & $\mathrm{X}$ & $x$ & $\mathrm{x}$ & $x$ \\
\hline Calcärio & $\mathrm{X}$ & $x$ & $X$ & $\mathrm{X}$ & $x$ & $\mathrm{X}$ & $x$ & $x$ & $\mathrm{X}$ \\
\hline Dolomito & $X$ & $X$ & $X$ & $X$ & $x$ & $\mathrm{X}$ & $X$ & $x$ & $X$ \\
\hline Gnaisse & & & & & $x(2)$ & $X$ & $x$ & $x$ & $x$ \\
\hline Granito & & $X(1)$ & & $X(1)$ & $x(2)$ & $x$ & $x$ & $X$ & $\mathrm{X}$ \\
\hline Mārmore & $x$ & $\mathrm{X}$ & $X$ & $\mathrm{X}$ & $x(2)$ & $x$ & $X$ & $x$ & $\mathrm{X}$ \\
\hline Quartzito & & $\mathrm{X}$ & $x$ & $\mathrm{X}$ & $\mathrm{X}$ & $\mathrm{X}$ & $x$ & $X$ & $x$ \\
\hline Sodalita & & $X$ & $X$ & $\mathrm{X}$ & $X(2)$ & $x$ & $X$ & $x$ & $x$ \\
\hline Talco & & $x$ & $\mathrm{X}$ & $x$ & $X$ & $X$ & $x$ & $x$ & $x$ \\
\hline Xisto & & & $\mathrm{X}$ & $x$ & $x$ & $\mathrm{X}$ & $\bar{x}$ & $\mathrm{X}$ & $x$ \\
\hline
\end{tabular}

(1) ünica rocha do item "pedra britada e oxnamental"

(2) a partir da edição desse ano integrante do item "pedra britada e ornamental". 
Anteriormente à década de 1970 são encontrados apenas dados esparsos e entermitantes sobre as rochas na construção (Quadro 8 e Figura 1). De 1937 a 1948, eles foram extraídos de CAVALCANTI (1951), de 1949 a 1959, não foram encontradas referências, e a partir de 1960, foram extraídos do Anuärio Mineral Brasileiro (BRASIL, 1972 a 1980). A partir do Quadro 8 foi possível traçar a linha bảsica da tendência brasileira no setor (Figura 1), concluindo-se que, após longo período de relativa estabilidade, em que os incrementos de produção foram da ordem de $50 \%$ a $70 \%$, nas décadas de 1940 e 1950 , e de apenas 15\%, na década de 1960, houve extraordinärio crescimento, da ordem de $330 \%$, na dẻcada de 1970 .

Com relação às reservas, existem dados somente a partir de 1971 (Quadro 9 e Figura 2), que demonstram uma evolução bastante irregular, possivelmente causada pelas mudanças na sistemática de compilação e apresentação dos dados. A edição do Anuário Mineral Brasileiro de 1979 (dados de 1978) revela um aumento das reservas medidas em 175\%, em relação à de 1978 (dados de 1977), devido à consideração dos dados de relatórios de pesquisas aprovadas, são considerados até então (comunicação verbal de Aỳrton Sintoni), mas acusa uma redução da ordem de 40\% na edição de 1980 .

Quanto ao comércio exterior de märmore, os dados foram reunidos no Quadro 10 e representados graficamente na Figura 3. Para AZAMBUJA \& SILVA (1977), a exportação só alcançou expressão a partir de 1964, mas, segundo informação da Carteira de Comércio Exterior - CACEX, do Banco do Brasil, é somente após essa data que se dispõe de dados. A análise do comércio exterior foi complementada com dados do Minera1s Yearbook (UNITED STATES, 1978 A e B), apresentados no Quadro 11, atravēs dos quais são identificados os países importadores de rochas para construção, incluindo o mármore. Eles são a Aräbia Saudita, Dinamarca, Holanda, Hungria, 


\begin{tabular}{|c|c|c|c|c|}
\hline PRODUÇÃO & BRASILEIRA DE & $\begin{array}{rc}\text { QUADRO } & 8 \\
\text { MARMORE } & \text { PARA } \\
\end{array}$ & \multicolumn{2}{|c|}{ CANTARIA, EM TONELADAS } \\
\hline Ano & Produção & $\begin{array}{l}\text { Variação relativa } \\
\text { ao ano anterior }\end{array}$ & $\begin{array}{c}\text { Variação relativa } \\
\text { na dêcada }\end{array}$ & Fonte \\
\hline $\begin{array}{l}1937 \\
1938 \\
1939 \\
\end{array}$ & $\begin{array}{ll}14 & 870 \\
13 & 176 \\
13 & 687\end{array}$ & $\begin{array}{r}-11,39 \% \\
+\quad 3,87 \% \\
\end{array}$ & & \multirow[b]{2}{*}{ 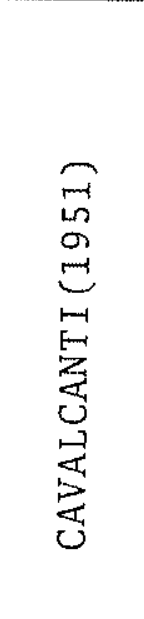 } \\
\hline $\begin{array}{l}1940 \\
1941 \\
1942 \\
1943 \\
1944 \\
1945 \\
1946 \\
1947 \\
1948 \\
1949\end{array}$ & $\begin{array}{ll}14 & 373 \\
18 & 092 \\
18 & 159 \\
17 & 522 \\
16 & 821 \\
17 & 271 \\
27 & 738 \\
12 & 722 \\
20 & 824\end{array}$ & $\begin{array}{r}+5,01 \% \\
+\quad 25,87 \% \\
+\quad 0,37 \% \\
\\
+\quad 4,50 \% \\
+\quad 2,00 \% \\
+\quad 6,67 \% \\
+\quad 60,60 \% \\
+\quad 54,13 \% \\
+\quad 63,68 \%\end{array}$ & $+52,14 \%$ & \\
\hline $\begin{array}{l}1950 \\
1951 \\
1952 \\
1953 \\
1954 \\
1955 \\
1956 \\
1957 \\
1958 \\
1959\end{array}$ & & & $+69,19 \%$ & 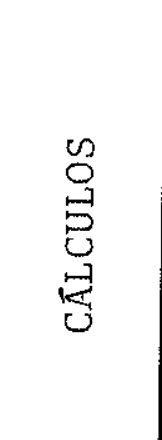 \\
\hline $\begin{array}{l}1960 \\
1961 \\
1962 \\
1963 \\
1964 \\
1965 \\
1966 \\
1967 \\
1968 \\
1969\end{array}$ & $\begin{array}{ll}35 & 233 \\
34 & 789 \\
34 & 299 \\
33 & 557 \\
56 & 833 \\
35 & 946 \\
35 & 347 \\
39 & 176 \\
34 & 434 \\
40 & 507\end{array}$ & $\begin{array}{l}-\quad 1,26 \% \\
-\quad 1,40 \% \\
-\quad 2,16 \% \\
+\quad 69,36 \% \\
-\quad 36,75 \% \\
-\quad 1,66 \% \\
+\quad 10,83 \% \\
-12,10 \% \\
+\quad 17,63 \%\end{array}$ & $+14,96 \%$ & \multirow{2}{*}{ 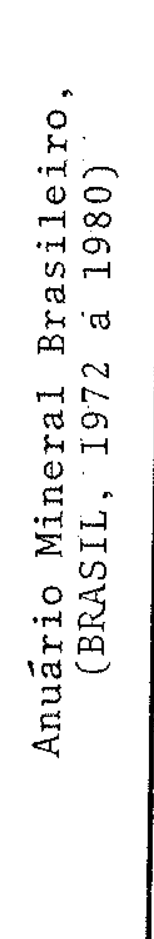 } \\
\hline $\begin{array}{l}1970 \\
1971 \\
1972 \\
1973 \\
1974 \\
1975 \\
1976 \\
1977 \\
1978 \\
1979\end{array}$ & $\begin{array}{rl}41 & 273 \\
33 & 493 \\
45 & 816 \\
66 & 887 \\
95 & 393 \\
130 & 055 \\
105 & 240 \\
145 & 257 \\
160 & 229 \\
177 & 290 \\
\end{array}$ & $\begin{array}{l}+1,89 \% \\
+\quad 18,80 \% \\
+\quad 36,79 \% \\
+45,99 \% \\
+\quad 42,61 \% \\
+\quad 36,33 \% \\
-19,08 \% \\
+\quad 38,02 \% \\
+10,30 \% \\
+10,64 \%\end{array}$ & $+329,55 \%$ & \\
\hline
\end{tabular}




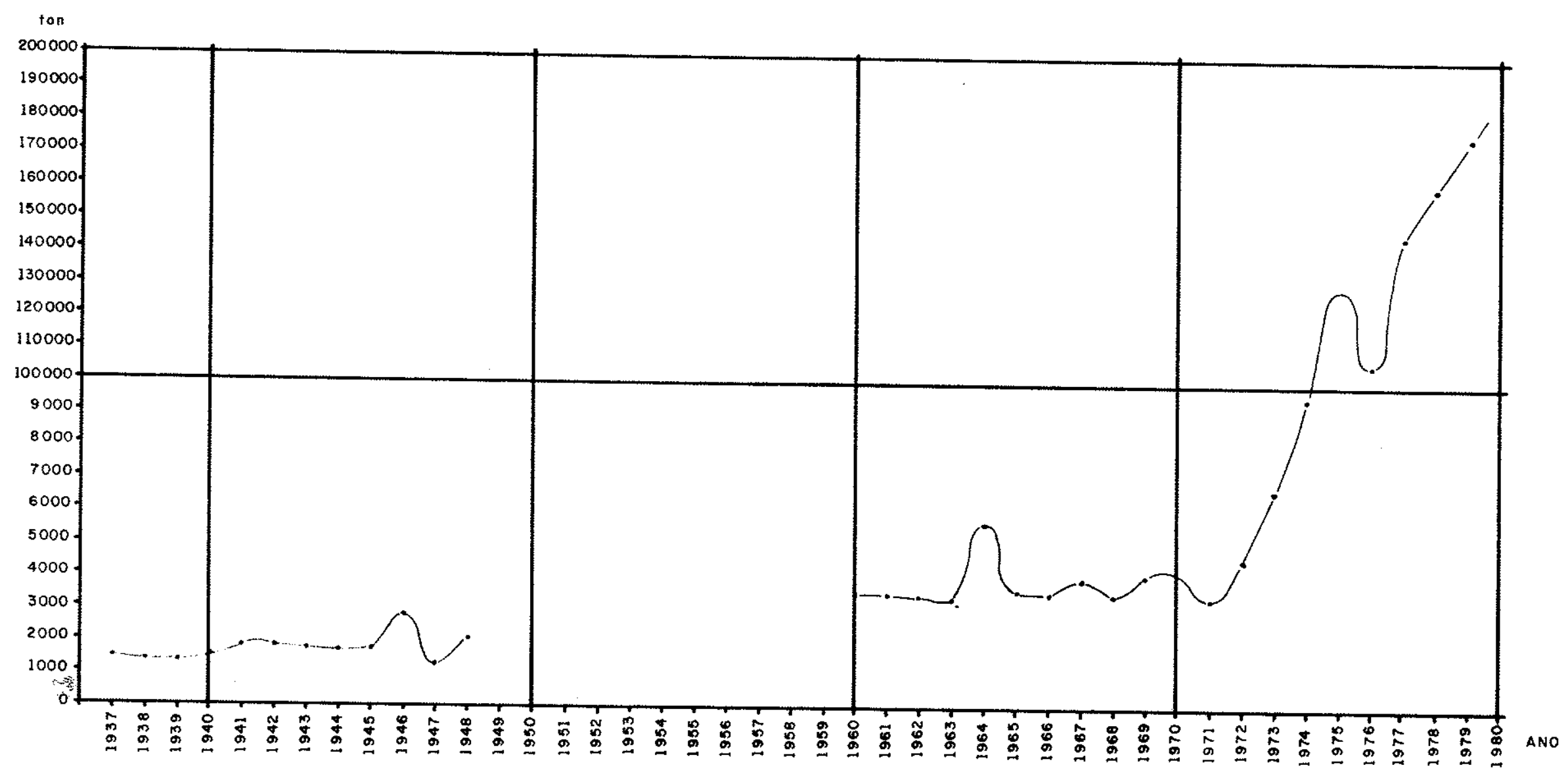

Figura 1 - Evolução da produção brasileira de märmore, em toneladas. 


\begin{tabular}{|c|c|c|c|c|c|c|c|c|c|}
\hline \multirow{3}{*}{ Ano } & \multicolumn{3}{|c|}{ MEDIDA } & \multicolumn{3}{|c|}{ INDICADA } & \multicolumn{3}{|c|}{ INFERIDA } \\
\hline & \multirow{2}{*}{ Quantidade } & \multicolumn{2}{|c|}{ Variaçäo \% } & \multirow{2}{*}{ Quantidade } & \multicolumn{2}{|c|}{ Variação \% } & \multirow{2}{*}{ Quantidade } & \multicolumn{2}{|c|}{ Variação : } \\
\hline & & No ano & $\mathrm{Na}$ década & & No ano & Na dëcada & & No ano & $\mathrm{Na}$ década \\
\hline 1970 & & & \multirow{10}{*}{$+337,70$} & & & \multirow{10}{*}{$+176,22$} & & & \multirow{10}{*}{$+124,20$} \\
\hline 1971 & 152125000 & & & 140584000 & & & 162363000 & & \\
\hline 1972 & $210533 \quad 309$ & $+\quad 38,39$ & & $120 \quad 333973$ & $+14,40$ & & 422906026 & $+160,46$ & \\
\hline 1973 & 213025403 & $+\quad 1,18$ & & 189066183 & $+57,11$ & & 205188990 & - $\quad 51,48$ & \\
\hline 1974 & 407549926 & $+91,31$ & & 290572393 & $+53,68$ & & $418 \quad 301239$ & $+103,86$ & \\
\hline 1975 & $394 \quad 112935$ & $-\quad 3,29$ & & $291 \quad 136501$ & $+\quad 0,19$ & & $327 \quad 120 \quad 208$ & $-21,79$ & \\
\hline 1976 & $451 \quad 920157$ & $+14,66$ & & 316.536599 & $+8,72$ & & $428 \quad 315306$ & $+\quad 30,93$ & \\
\hline 1977 & $420356 \quad 000$ & $-6,98$ & & 317302000 & $+0,24$ & & 149521000 & - 65,65 & \\
\hline 1978 & 1158379000 & $+175,57$ & & 422906000 & $+33,28$ & & $\begin{array}{lll}533 & 015000\end{array}$ & $+256,48$ & \\
\hline 1979 & 665858000 & $-\quad 42,51$ & & $388 \quad 324 \quad 000$ & $-\quad 8,17$ & & 364031000 & - $\quad 31,70$ & \\
\hline
\end{tabular}

Fonte: Anuário Mineral Brasileiro (BRASIL, 1972 a 1980) 


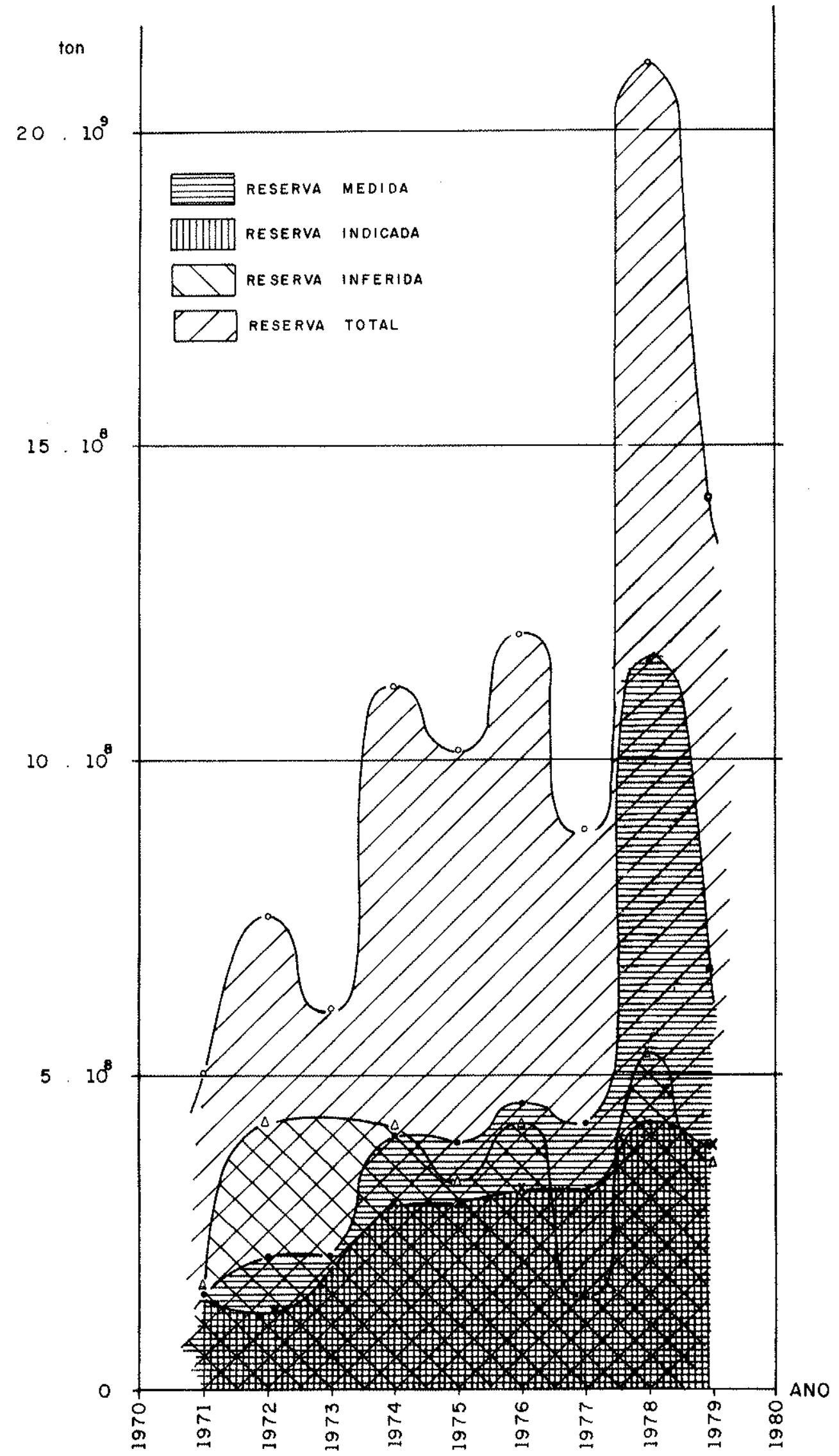

Figura 2 - Evolução das reservas brasileiras de märmores, em toneladas. 


\begin{tabular}{|c|c|c|c|c|c|c|c|}
\hline \multicolumn{8}{|c|}{$\begin{array}{ll} & \text { QUADRO } 10 \\
\text { COMERCIO EXTERIOR BRASILEIRO DE MARMORE PARA CANTARIA, EM TONELADAS }\end{array}$} \\
\hline NO & IMPORTAÇÃOO & $\begin{array}{c}\text { VARIACCAO } \\
\text { ANUALL }\end{array}$ & $\begin{array}{l}\text { VARIACEAO } \\
\text { DECADA } \\
\end{array}$ & EXPORTAÇÃO & $\begin{array}{c}\text { VARIACCAO } \\
\text { ANUAL }\end{array}$ & $\begin{array}{c}\text { VARIACCAO } \\
\text { DECADA }\end{array}$ & FONTE \\
\hline $\begin{array}{l}1941 \\
1942 \\
1943 \\
1944 \\
1945 \\
1946 \\
1947 \\
1948 \\
1949\end{array}$ & $\begin{array}{rl}6 & 687 \\
5 & 263 \\
3 & 985 \\
3 & 709 \\
6 & 673 \\
9 & 352 \\
14 & 699 \\
18 & 497 \\
4 & 041\end{array}$ & $\begin{array}{r}-21,29 \% \\
-24,24 \% \\
-\quad 6,92 \% \\
+79,91 \% \\
+40,14 \% \\
+57,17 \% \\
+\quad 27,21 \% \\
-77,60 \%\end{array}$ & $-39,56 \%$ & $\begin{array}{r}280 \\
698 \\
53 \\
24 \\
68 \\
22 \\
69\end{array}$ & $\begin{array}{l}+149,28 \% \\
-92,40 \% \\
-54,71 \% \\
+183,33 \% \\
-67,64 \% \\
+213,63 \%\end{array}$ & $-75,35^{\circ}$ & 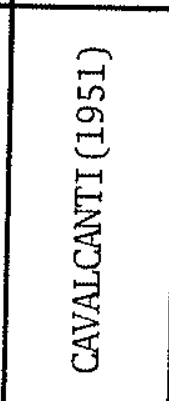 \\
\hline $\begin{array}{l}1950 \\
1951 \\
1952 \\
1953 \\
1954 \\
1955 \\
1956 \\
1957 \\
1958 \\
1950\end{array}$ & & & & & & & \% \\
\hline $\begin{array}{l}1960 \\
1961 \\
1962 \\
1963 \\
1964 \\
1965 \\
1966 \\
1967 \\
1968 \\
1969 \\
\end{array}$ & 136 & & $-96,63^{\circ}$ & & & $-14,49 \%$ & 窎 \\
\hline $\begin{array}{l}1970 \\
1971 \\
1972 \\
1973 \\
1974 \\
1975 \\
1976 \\
1977 \\
1978 \\
1979\end{array}$ & $\begin{array}{rr}1 & 017 \\
& 668 \\
1 & 069 \\
6 & 428 \\
3 & 032 \\
& 453 \\
& 256 \\
& 295 \\
& 73 \\
& 148\end{array}$ & $\begin{array}{l}+647,79 \% \\
-34,31 \% \\
+37,51 \% \\
+501,30 \% \\
-52,83 \% \\
-85,05 \% \\
-43,48 \% \\
+15,23 \% \\
-75,25 \% \\
+102,73 \%\end{array}$ & $-85,44^{\circ}$ & $\begin{array}{rr} & 59 \\
& 175 \\
& 316 \\
& 226 \\
1 & 278 \\
1 & 474 \\
& 276 \\
1 & 330 \\
2 & 296 \\
2 & 969\end{array}$ & $\begin{array}{l}+196,61 \% \\
+80,57 \% \\
-28,48 \% \\
+465,48 \% \\
+15,33^{\circ} \\
-81,27 \% \\
+381,880^{\circ} \\
+42,07 \% \\
+\quad 29,31 \%\end{array}$ & $+4 \underset{\frac{0}{6}}{932,20}$ & 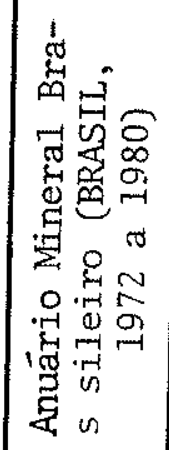 \\
\hline
\end{tabular}




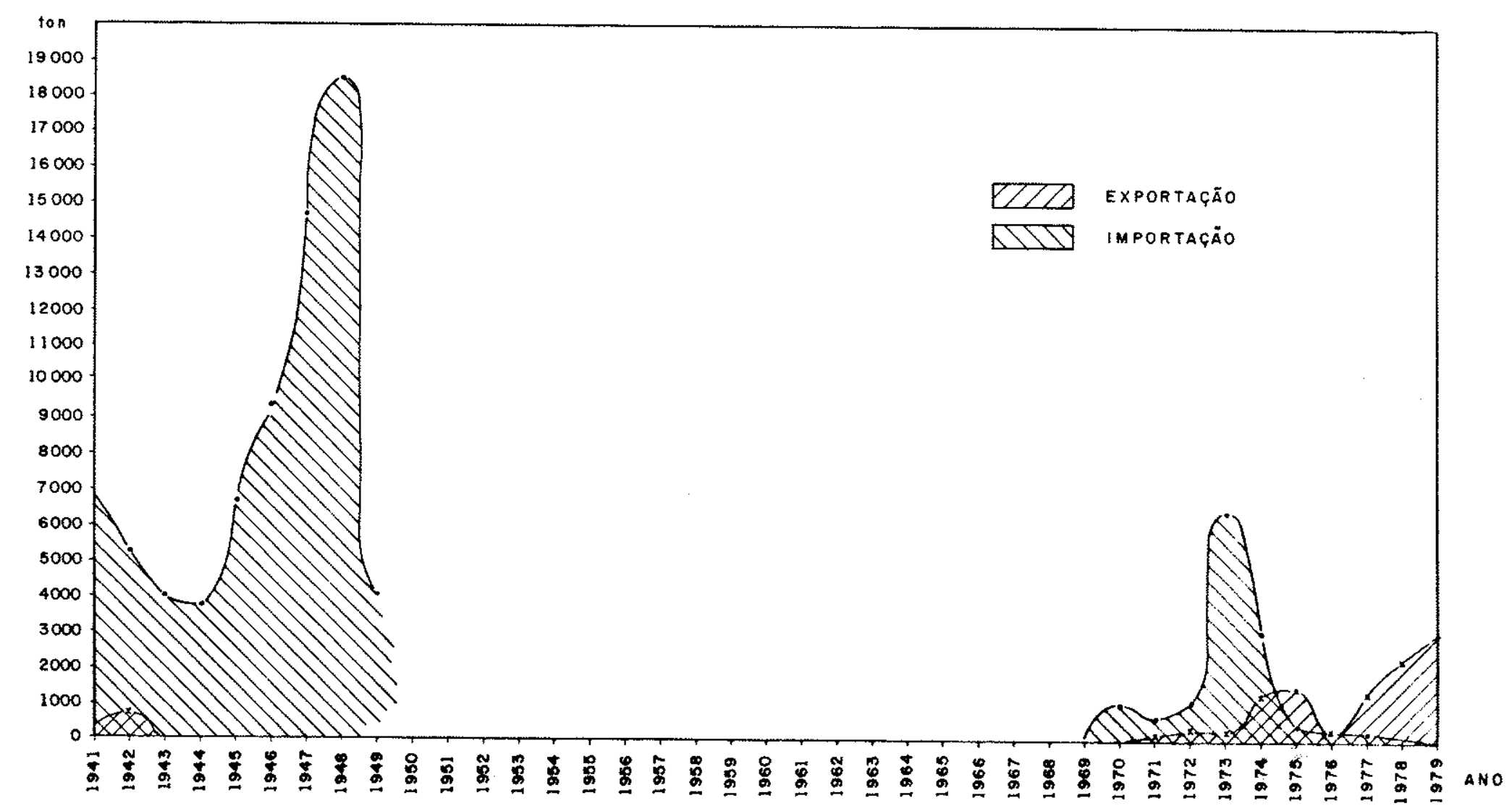

Figura 3 - Evolução so comércio exterior brasileiro de märmore, em toneladas 
$-55-$

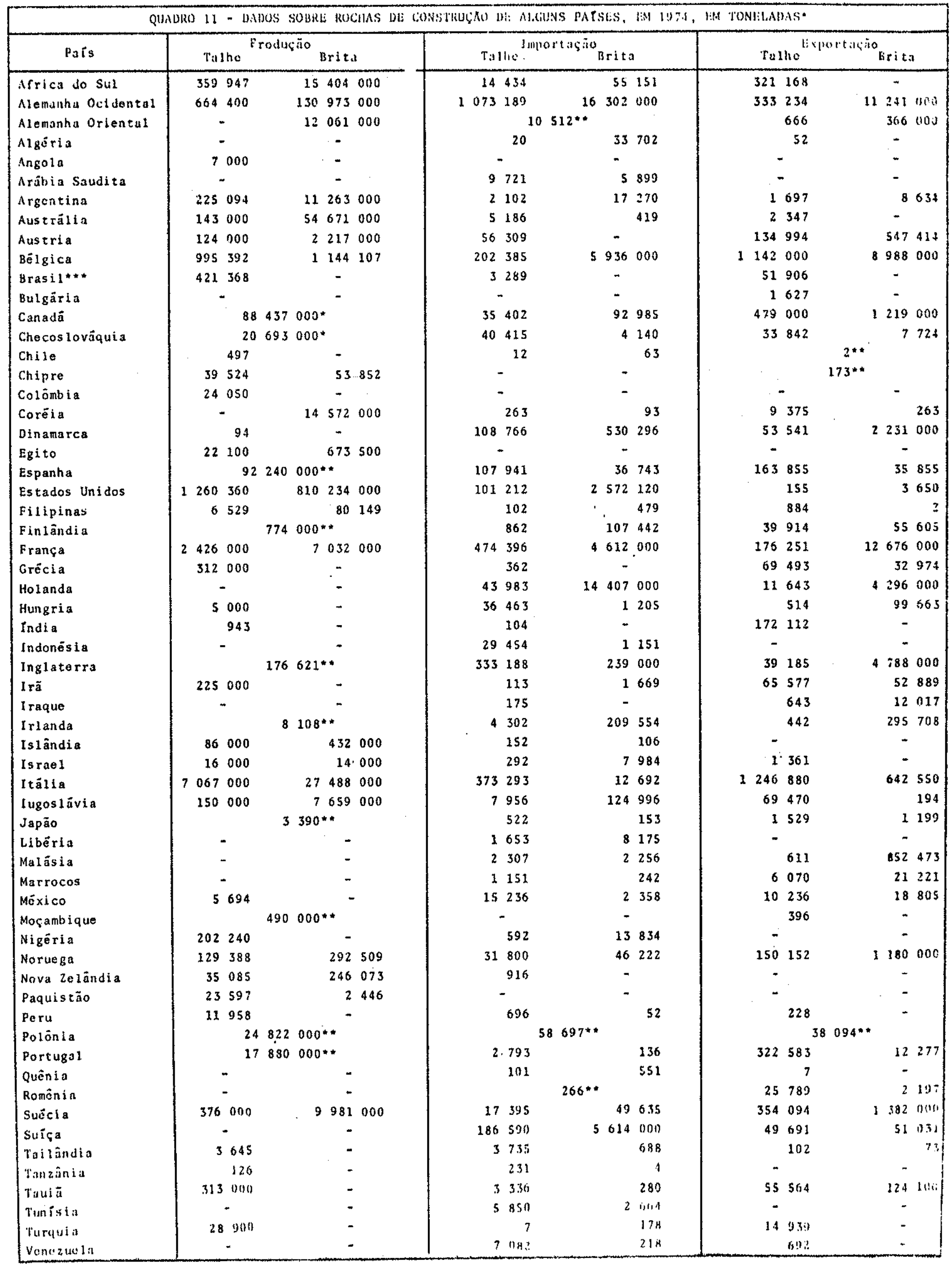

* Fonte Minerals Yearbook (UNITED STATES, 1978 A e B)

* Totais globais (talhe + brita)

***Ver Quadros 8, 9 e 10 e Figuras 1,2 e 3 
Indonẻsia, Iraque, Libëria, Malásia, Marrocos, Mëxico,Quênia, Romênia, Suiça, Tunísia e Venezuela. Desses, alguns são importantes para o Brasil, ou por serem fronteiriços, como a Venezuela, ou pröximos, como o México, outros são seus exportadores como a Aräbia Saudita e o Iraque, representando mercados potenciais para conquista. 
3 - GEOLOGIA DAS ROCHAS CARBONĀTICAS

\section{1 - Mineralogia dos Carbonatos}

Os minerais carbonatos, constituintes fundamentais do mármore, são classificados quimicamente como sais do ácido carbônico- $\mathrm{H}_{2} \mathrm{CO}_{3}$, ou como oxissais de oxigênio em coordenação ternäria (KLOCKMAN \& RANDOHR, 1961), caracterizados pelo radical carbonato $-\mathrm{CO}_{3}{ }^{--}$.

0 ânion carbonato resulta da tendência do carbono se combinar com o oxigênio, numa relação de raios atômicos que define uma estrutura triangular. Como a carga elétrica de cada ligação C-0, nessa estrutura, é maior que a metade da carga de cada oxigênio (HURLBUT, 1941), os oxigênios são ligados mais fortemente ao carbono que a qualquer outro cátion do retículo cristalino fazendo com que o ânion carbonato constitua unidades integras, seja nos retículos minerais, seja em solução (BETEJTIN, s.d.p.).

Em função dessa natureza elétrica e da forma geométrica, esse íon é responsável pela maioria das propriedades físicas e químicas dos minerais, em que entre como parte fundamental.

Quimicamente, os carbonatos são decomponíveis pelos ấcidos em anidrido carbônico - $\mathrm{CO}_{2}$, com maior ou menor facilidade confọme o tipo de câtion e a temperatura do ăcido. A reação ê caracterizada pela efervescência, representada genericamente pela equação:

\begin{tabular}{|c|c|c|c|c|}
\hline $\mathrm{XCO}_{3}$ & + & & $\stackrel{\uparrow}{\mathrm{CO}_{2}}$ & $+\mathrm{HY}_{2}+\mathrm{H}_{2} \mathrm{O}$ \\
\hline & & ácido & anidrido carbônico & água \\
\hline
\end{tabular}


A decomposição dos carbonatos pode ocorrer, tambëm, por aquecimento, segundo a equação: $\mathrm{XCO}_{3}$

carbonato

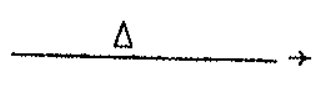

aquecimento
$\mathrm{CO}_{2}$

anidrido carbônico

Esse comportamento dos carbonatos $\vec{e}$ devido à instabilidade de seu radical $\mathrm{CO}_{3}^{--}$que, em presença do íon $\mathrm{H}^{+}$, ou por ação do calor, transforma-se em $\mathrm{CO}_{2}$; composto mais estavel por ser eletricamente neutro e sustentado por 1igações mais fortes.

Nas equações químicas acima o $X$ representa, principalmente, cảtions metälicos bivalentes, formadores dos minerais chamados carbonatos anidros (KLOCKMAN \& RANDOHR, 1961 ; BETEJTIN, s.d.p.). Com raio atômico de $0,99 \AA$, o cảlcio ocupa posição intermediāria na relação dos cātions bivalentes (Quadro 12), separando-os em dois grupos: cátions de maiores e cátions de menores raios atômicos (BETEJTIN,
s.d.p.).

Quando o ín carbonato se combina com cätions de raios atômicos menores que o do cálcio, a relação entre suas dimensões impõe que cada cátion fique coordenado a seis oxigênios e cada oxigênio a um carbono e a dois cātions, dispostos segundo uma estrutura parecida com a do NaCl. Para a visualização desta semelhança, imagina-se o cristal cübico de halita orientado com seu eixo de simetria ternária navertical. Nessa posição, o sỏdio ë substituído pelo cảtion e o cloro pelo ânion carbonato.

o achatamento do íon carbonato, em relação à esfericidade de ion cloreto, provoca a deformação da estrutura cübica, em que as faces forman triedros de $90^{\circ}$, para romboedros, em que as faces estão a $107^{\circ}$ aproximadamente, ou seu suplemento. Como resultado tem-se uma simetria trigonal, 


\section{QUADRO 12}

CORRELAÇĀO CRISTALOGRĀFICA DOS CARBONATOS ANIDROS DE METAIS BIVALENTES COM SEUS RAIOS ATÔMICOS

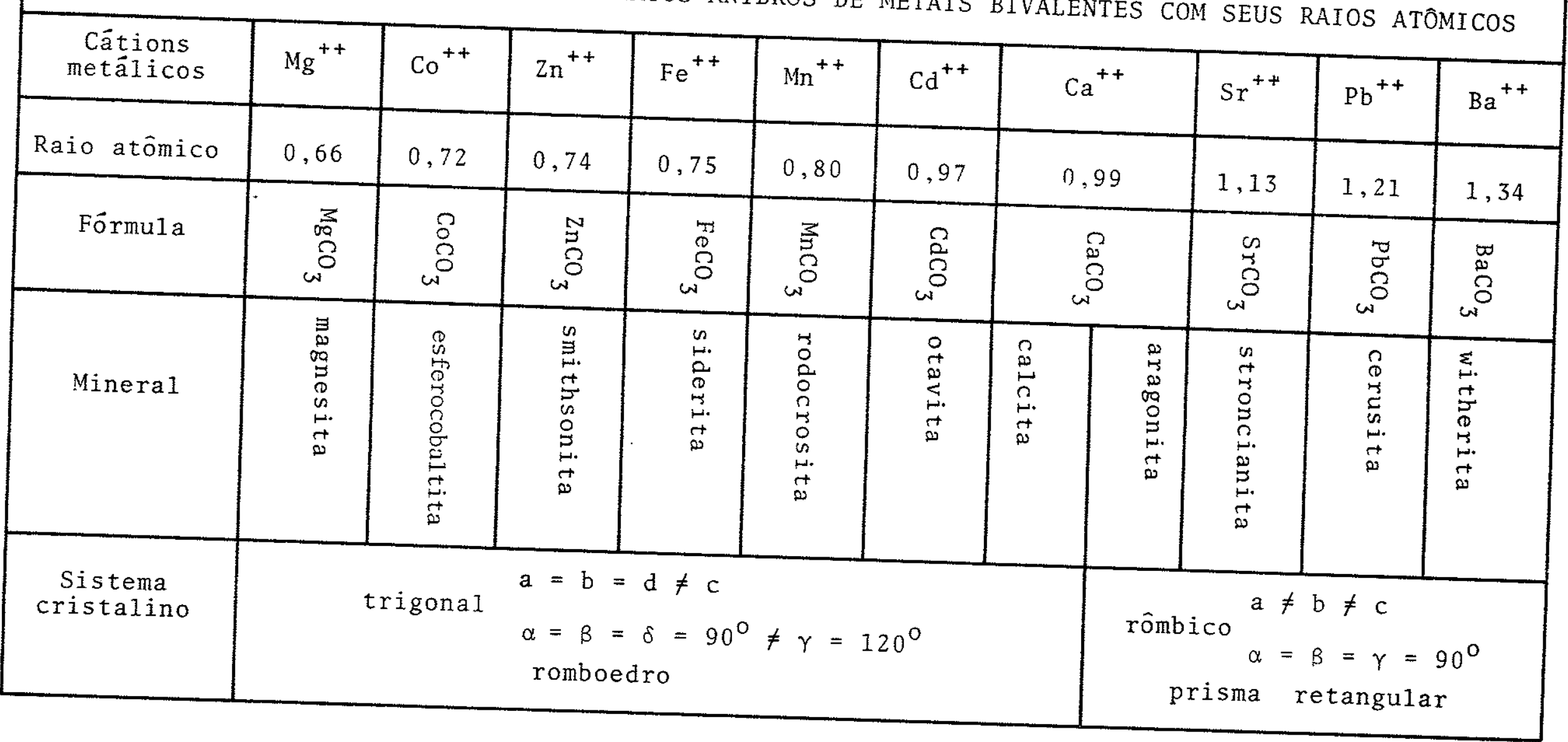


constituindo um grupo cristalogräfico de minerais isomorficos, chamado GRUPO DA CALCITA, ou GRUPO DOS CARBONATOS ROMBOEDRICOS, ou ainda GRUPO DOS CARBONATOS ESPATICOS (BETEJTIN, s.d.p.; HURLBUT, 1941 ; LAPADU-HARGUES, 1954 ; KLOCKMAN \& RANDOHR, 1961).

A estrutura cristalina desse grupo mineral, devido à morfologia plana do íon carbonato, è caracterizada pelo desenvolvimento de níveis de cảtions metảlicos alternados com níveis de ânions carbonâticos. A participação de um elemento metảlico nessa estrutura ë regida pela relação entre seus raios atômicos. Assim, nos minerais do grupo, a permuta entre ferro, manganês, zinco e magnẻsio, $\vec{e}$ comum e se da em todas as proporções, formando soluções sôlidas.

A substituição do cálcio pelo magnêsio, ou vice-versa, não $\vec{e}$ uniforme devido à grande diferença entre seus raios atômicos. Nesses casos, ao conträrio de soluções sölidas, formam-se reticulos estratificados, com niveis alternados de magnësio, carbonato e cälcio, em proporções pröximas de $1: 1$, resultando o mineral dolomita.

A morfologia plana do ion carbonato é responsāve 1 por boa parte das propriedades físicas dos carbonatos romboëdricos, tais como a dupla refração, a clivagem perfeita (paralela aos planos de mäxima concentração de íons carbonato), a baixa dureza (sempre inferior a 5), a alta solubilidade. Apenas a densidade $\vec{e}$ mais ligada ao cátion metälico, proporcional ao seu peso atômico. Isso ocorre porque, embora o ion carbonato seja sustentado por ligações parcialmente covalentes, sua ligação ao cátion metảlico é iônica. A única anomalia e representada pelo magnësio, de raio atômico muito menor que o dos demais metais do grupo, mas com empacotamento cristalino na magnesita mais denso que nos demais minerais da sërie. 
Quando o ín carbonato se combina com metais bivalentes de raios atômicos maiores que o do cālcio, a relação entre as dimensões dos elementos envolvidos favorece o desenvolvimento de estruturas rômbicas. Nessas estruturas cada cảlcio estâ coordenado a três ions carbonato, isto $\vec{e}$ a nove oxigênios, e cada oxigênio estâ ligado a três cälcios. Nesses casos ocorre, igualmente, o desenvolvimento de níveis catiônicos intercalados com níveis aniônicos,perpendiculares ao eixo vertical, com a formação de faces de prismas com ângulos de $62^{\circ}-63^{\circ}$, originando formas parecidas com as do retículo hexagonal, chamadas pseudo-hexagonais. os produtos pertencem a um outro grupo cristalogräfico de minerais carbonāticos, chamado GRUPO DA ARAGONITA, ou GRUPO DOS CARBONATOS RÔMBICOS (BETEJTIN, s.d.p.; HURLBUT, 1941; LAPADU-HARGUES, 1954 ; KLOCKMAN \& RANDOHR, 1961).

A cristalização dos minerais carbonatos de metais bivalentes $\vec{e}$, portanto, função direta do tamanho do cätion envolvido. Como o cảlcio tem dimensões intermediärias dentre a série, ele pode cristalizar-se em ambas as formas (calcita e aragonita), se bem que a aragonita $\vec{e}$ instäve 1 e transforma-se automaticamente em calcita, mesmo nas condições ambientais.

Alëm dos minerais do Quadro 12 existem os carbonatos anidros de cätions mono e trivalentes e os carbonatos hidratados, porêm, de pequena importância do ponto de vista de sua ocorrência na crosta.

Os principais minerais carbonatos formadores de rochas são a calcita e a dolomita. Os demais são raros e, quando ocorrem em concentrações econômicas, são utilizados na indústria de transformação para obtenção de produtos químicos e metais; jamais como pedras de construção. 


\section{2 - Físico-Química da Sedimentação Carbonātica}

Embora os aspectos físicos e químicos das rochas carbonáticas tenham sido intensa e extensivamente estudados, muitos problemas sobre o comportamento dos carbonatos, ainda estão por ser resolvidos (BRINKMANN, 1964). Apesar da existência de exemplares formados por atividades magmâticas (TUTTLE \& GITTINS, 1966), a maior parte deles é precipitada por reações de compostos da crosta com compostos atmosféricos.

Sabe-se que sua formação se dá em locais ausentes de sedimentos detríticos, por processos orgânicos ou inorgânicos, em águas rasas ou profundas, marinhas ou continentais, em função do pH do meio. 0 pH, depende da concentração de anidrido carbônico dissolvido na água formando o acido carbônico - $\mathrm{H}_{2} \mathrm{CO}_{2}$, comumente dissociado em íons hidrogênio $-\mathrm{H}^{+}$, ions bicarbonato $-\mathrm{HCO}_{3}^{-}$e ions carbonato $-\mathrm{CO}_{3}^{--}$, atravẻs da seguinte reação reversível:

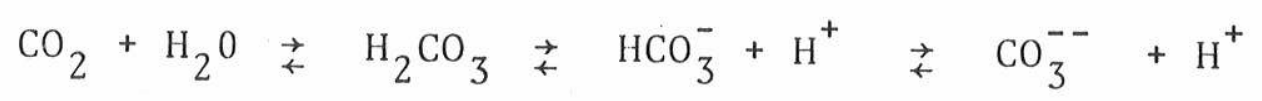

$\mathrm{O}_{2} \mathrm{CO}_{3}$ é um ảcido fraco, mas suficientemente enérgico para dissolver os carbonatos. Quanto maior for sua concentração, maior será sua atividade, segundo a seguinte equação química genërica:

$$
\mathrm{XCO}_{3}+\mathrm{H}^{+}+\mathrm{HCO}_{3}^{-} \stackrel{\rightarrow}{\leftarrow} \mathrm{X}^{++}+2 \mathrm{HCO}_{3}^{-}
$$

em que o X pode representar $\mathrm{Mg}^{++}, \mathrm{Ca}^{++}, \mathrm{Sr}^{++}, \mathrm{Ba}^{++}, \mathrm{Mn}^{++}$, $\mathrm{Fe}^{++}, \mathrm{Co}^{++}, \mathrm{Ni}^{++}, \mathrm{Cu}^{++}, \mathrm{Zn}^{++}, \mathrm{Cd}^{++} \mathrm{Ou} \mathrm{Pb}^{++}$. Esses cátions são oriundos dos minerais prexistentes, por decomposição intempérica. Os feldspatos, feldspatóides, micas, piroxênios, anfibólios, particularmente sensíveis ao intemperis-

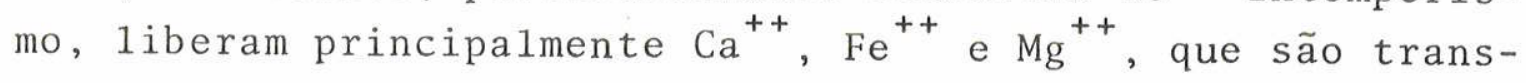


portados em solução para o mar.

Para BRINKMANN (1964), afora a dissolução a partir da atmosfera, durante as chuvas, ou por difusão superficial, com a qual o mar está em contato, o conteúdo de $\mathrm{CO}_{2}$ e de ânions carbonato nos oceanos, provêm de emanações vulcânicas submarinas. Para MASON (1971), além do controle atmosfërico, o conteưdo de diōxido de carbono, nas äguas marinhas superficiais, depende da natureza e da intensidade da atividade biolögica.

O conteúdo de ânions carbonato, na ägua do mar, foi representado graficamente por Buch \& Kalle em 1943, e simplificado por BRINKMANN (1964). Com o aumento da quantidade de $\mathrm{CO}_{2}$, o equilíbrio das reações acima $\vec{e}$ deslocado para a direita do gräfico (Figura 4), isto é, no sentido da dissolução dos carbonatos, por induzir a formação do íon bicarbonato, muito mais solúvel que o carbonato. E, com a diminuição da mesma, o equilïbrio ê deslocado para a esquerda, no sentido da cristalização.

Aguas frias e profundas, em geral com grande quantidade de $\mathrm{CO}_{2}$, impedem a precipitação de carbonatos e águas quentes e rasas, que contêm $\mathrm{CO}_{2}$ em pequenas quantidades, reunem condições para a precípitação ou sintetização orgânica.

O peso do conteúdo total de íons dissolvidos na ãgua do mar è denominado salinidade e è expresso em \%oo(partes por mil). Apesar de certas variações, no tempo geológico e no espaço restrito, ele pode ser considerado uniforme em toda a extensão horizontal e vertical dos oceanos abertos, com valor de $35^{\circ} / 00$ (Quadros 13 e 14). Para ser conhecido o limite entre a precipitação e a dissolução dos carbonatos, no sistema representado pela ägua do mar, com inümeros ions em solução, basta determinar os produtos de solubilidade -K (Quadro 14). 


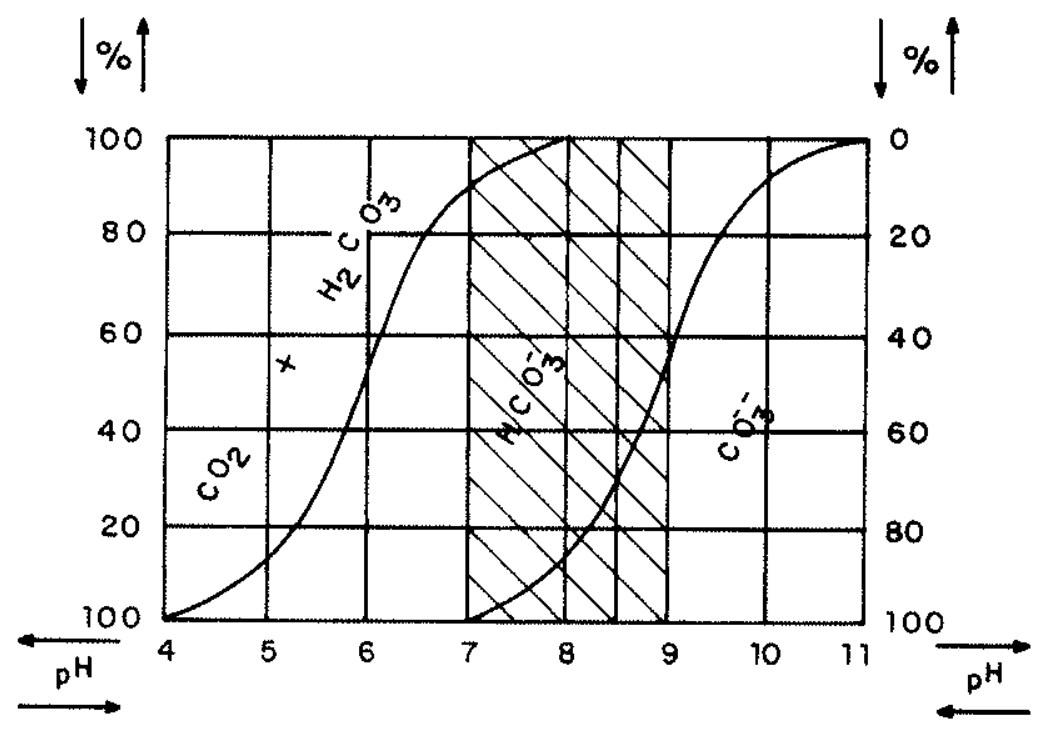

Figura 4 - Conteúdo porcentual dos ions carbonato e bicarbonato na água do mar de salinidade de $35 \%$ o (simplificação de BRINKMANN(1964) a partir de Buch e Kal1e, em 1943). A zona achuriada representa o âm bito de $\mathrm{pH}$ onde predominam ions carbonato.

Segundo KRAUSKOPF (1972), para equilibrar as quantidades de $\mathrm{Ca}^{++}$e de $\mathrm{CO}_{3}^{--}$medidas na ägua do mar, é preciso aumentar os produtos de solubilidade dos carbonatos em 50 vezes. Esse ajuste é empírico e, apenas, dä noção da ordem de grandeza, mas explica a abundância relativa dos vários compostos carbonáticos na natureza, bem como suas mütuas substituiçöes. Para se conhecer as concentrações em que ocorrem substituições, basta dividir os respectivos produtos de solubilidade. Por exemplo, a substituição de calcita por siderita ocorre quando a primeira estiver em contato com uma solução em que a concentração de $\mathrm{Fe}^{++}$for maior que $1 / 150$ da de $\mathrm{Ca}^{++}$, pois $4,5 \cdot 10^{-9}: 3,0 \cdot 10^{-11}=150 . \quad \mathrm{Da}$ mesma forma, a siderita será substituída por calcita quando a concentração de $\mathrm{Ca}^{++}$for 150 vezes superior que a de $\mathrm{Fe}^{++}$.

- $\mathrm{SrCO}_{3} \vec{e}$ o unico composto cuja saturação se aproxima da do $\mathrm{CaCO}_{3}$, explicando a frequente presença de es- 


\begin{tabular}{|c|c|c|c|c|c|c|c|c|}
\hline QUADRO & $3-$ CONTEO & ANIÔNIC & FORMADOR I & CARBONATOS & M AGUAS MA & INHAS E & FLUVIAIS & \\
\hline \multirow[t]{2}{*}{ constituinte } & \multicolumn{4}{|c|}{$\vec{a} \mathrm{gua}$ do mar } & \multicolumn{3}{|c|}{$\bar{a} g u a d o c e d u r a$} & $\begin{array}{c}\text { ägua doce } \\
\text { branda }\end{array}$ \\
\hline & $0 / 00(1)$ & $\% / 00(2)$ & $0 / 00(3)$ & mol/1itro (4) & $0 / 00(1)$ & $\operatorname{ppm}(3)$ & $0 / 0$ & $0 / 00(1)$ \\
\hline $\begin{array}{l}\text { Ion bicarbonato } \\
\mathrm{HCO}_{3}^{-}\end{array}$ & $11,6 \cdot 10^{-2}$ & $14,2.10^{-2}$ & $14,0 \cdot 10^{-2}$ & - & - & 58,5 & 48,6 & - \\
\hline $\begin{array}{l}\text { Ion carbonato } \\
\mathrm{CO}_{3}^{--}\end{array}$ & $1,2 \cdot 10^{-2}$ & - & - & $2,0.10^{-5}$ & $119.10^{-2}$ & - & - & $1,2 \cdot 10^{-2}$ \\
\hline
\end{tabular}

(1) - Segundo trabalho de Rubey, em 1951, para salinidade $35^{\circ} / 00$ (BRINKMANN, 1964).

(2) - Segundo trabalho de Culkin, em 1963, para salinidade 35\% (TUREKIAN, 1969).

(3) - Segundo trabalho de Livingstone, em 1963, para äguas marinhas e fluviais não. (MASON, 1971; KRAUSKOPF, 1972).

(4) - Segundo KRAUSKOPF (1972), o total de $\mathrm{CO}_{3}^{--}$na ägua do mar é da ordem de $0,0002 \mathrm{M}$. 


\begin{tabular}{|c|c|c|c|}
\hline \multicolumn{4}{|c|}{$\begin{aligned} \text { QUADRO } 14 \text { - CONTEUdDO CATIONICO FORMADOR DE CARBONATOS EM ĀGUAS MARINHAS A } 25^{\circ} \mathrm{C} \text { E SEUS PRODUTOS } \\
\text { DE SOLUBILIDADE (KRAUSKOPF, } 1972 \text { ) }\end{aligned}$} \\
\hline ion metá1ico & concentração mol/1itro & $\begin{array}{l}\text { K em äoua distiliada } \\
\left(X^{++}\right) \cdot\left(\mathrm{CO}_{3}\right)\end{array}$ & $\begin{array}{l}\text { concentração possivel equilibrada } \\
\qquad \begin{array}{l}\operatorname{com} \mathrm{CO}_{3} \\
\mathrm{~mol} / \mathrm{i} \text { tro }\end{array}\end{array}$ \\
\hline $\mathrm{Mg}^{++}$ & $5,4 \cdot 10^{-2}$ & $2,0.10^{-5}$ & $5,0.10^{1}$ \\
\hline $\mathrm{Ca}^{++}$ & $1,0 \cdot 10^{-2}$ & $4,5 \cdot 10^{-9}$ & $1,0 \cdot 10^{-2}$ \\
\hline $\mathrm{Sr}^{++}$ & $9,0.10^{-5}$ & $2,5 \cdot 10^{-10}$ & $6,0 \cdot 10^{-4}$ \\
\hline $\mathrm{Fe}^{++}$ & $2,0 \cdot 10^{-7}$ & $3,0 \cdot 10^{-11}$ & $8,0 \cdot 10^{-5}$ \\
\hline $\mathrm{Zn}^{++}$ & $1,5.10^{-7}$ & $1,5 \cdot 10^{-11}$ & $4,0 \cdot 10^{-5}$ \\
\hline $\mathrm{Ba}^{++}$ & $5,0 \cdot 10^{-8}$ & $1,6 \cdot 10^{-9}$ & $4,0 \cdot 10^{-3}$ \\
\hline $\mathrm{Cu}^{++}$ & $5,0 \cdot 10^{-8}$ & $2,5 \cdot 10^{-10}$ & $6,5 \cdot 10^{-4}$ \\
\hline $\mathrm{Mn}^{++}$ & $4,0 \cdot 10^{-8}$ & $6,0 \cdot 10^{-11}$ & $1,5 \cdot 10^{-4}$ \\
\hline $\mathrm{Pb}^{++}$ & $1,5 \cdot 10^{-8}$ & $8,0.10^{-14}$ & $2,0.10^{-7}$ \\
\hline $\mathrm{Co}^{++}$ & $1,0 \cdot 10^{-8}$ & $1,6 \cdot 10^{-13}$ & $4,0 \cdot 10^{-7}$ \\
\hline $\mathrm{Ni}^{++}$ & $1,0.10^{-8}$ & $1,4 \cdot 10^{-7}$ & $3,5 \cdot 10^{-1}$ \\
\hline $\mathrm{Cd}^{++}$ & $1,0 \cdot 10^{-9}$ & $5,2 \cdot 10^{-12}$ & $1,0.10^{-5}$ \\
\hline
\end{tabular}


trôncio em calcitas.

A concentração de $\mathrm{Ba}^{++} \overrightarrow{\mathrm{e}}$ baixa porque o sulfato de bärio é mais insolüvel que $\mathrm{o}^{\mathrm{BaCO}_{3}}$ e porque a concentração de $\mathrm{SO}_{4}^{--}$, na ägua do mar, é maior que a do $\mathrm{CO}_{3}^{--}$.

O teor de $\mathrm{Mg}^{++}$tambëm ë baixo pela lenta formação de dolomita e de argilas.

$0 \mathrm{Fe}^{++}$e $\mathrm{O} \mathrm{Mn}^{++}$não podem atingir altas concentrações, na ägua do mar, por serem oxidados e precipitados sob forma de óxidos de valência superior.

Em vista do conteüdo mëdio de íons de cälcio e de carbonato, a ảgua do mar é quase saturada desse composto, principalmente nas zonas equatoriais. Para BRINKMANN(1964), entretanto, não ocorre precipitação espontânea de carbonato de cảlcio, porque ê possível que tais conteúdos, determinados analiticamente, não estejam realmente disponíveis. No entanto, ocorre precipitação inorgânica de bicarbonatos, segundo a equação reversíve1

\begin{tabular}{|c|c|c|c|c|}
\hline $\mathrm{CaCO}_{3}$ & $\mathrm{CO}_{2}$ & $+\mathrm{H}_{2} \mathrm{O}$ & $\rightarrow$ & $\mathrm{CaH}_{2}\left(\mathrm{CO}_{3}\right)_{2}$ \\
\hline carbonato & anidrido & ägua & & bicarb \\
\hline insolüve 1 & carbônico & & & solüvel \\
\hline
\end{tabular}

sempre que houver: 1- elevação da temperatura que, para da-

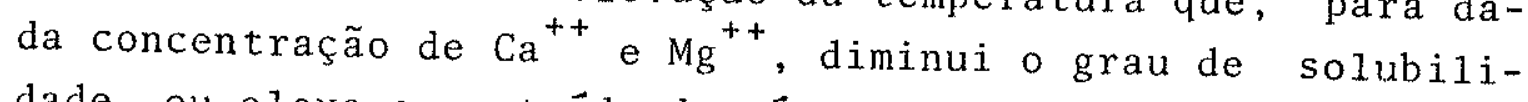
dade, ou eleva o conteüdo de cảtions pela menor dissolução de $\mathrm{CO}_{2} ; 2$ - abaix́mento da pressão hidrostätica; 3- redução da concentração salina; 4- intensa evaporação e 5- elevação do pH do meio.

Segundo Wattemberg (BRINKMANN, 1964), o coeficiente de solubilidade da calcita é reduzido à metade quando a 
temperatura varia de $0^{\circ} \mathrm{C}$ a $30^{\circ} \mathrm{C}$, ou è reduzido à $1 / 4$ quando a salinidade cai para a metade. A salinidade varia com a temperatura atravēs da evaporação, que determina a elevação da concentração salina. A variação do pH se dä por ascenção de massa de ägua fria profunda que reduz a dissolução do ácido carbônico pela queda da pressão hidrostätica.os calcärios inorgânicos são constituídos de oôlitos, partículas esféricas de granulação fina, formados sob intensa agitação (EICHER, 1969).

Entretanto, a formação do carbonato de cälcio a partir da āgua do mar, se dā, predominantemente, por processos orgânicos. Ela pode consistir da sintetização biológica, para as estruturas de sustentação ou proteção durante a vida dos animais planctônicos e acumulação, no fundo dos oceanos, após a morte dos mesmos. Para LAPORTE (1975), este fato explica a predominância de cloreto de sôdio nas águas do mar, apesar da predominância de carbonato de cālcio nas äguas dos rios. E que, enquanto grande quantidade de $\mathrm{CaCO}_{3} \vec{e}$ extraỉda da ägua do mar pelos organismos, sendo depositada como detritos que vão constituir terras emersas, - NaCl permanece em solução, sendo concentrado atravēs do tempo geolögico. As principais espécies animais responsäveis por esse processo são os foraminiferos, corais, crinóides, crustáceos, braquiöpodes, pelecípodos, gasterópodos e cefalópodos. Alëm deles, as algas tambëm desempenham importante papel na precipitação de carbonatos, através de sua atividade fotossintetizadora, retirando $\mathrm{CO}_{2}$ dissolvido nas àguas.

A atividade orgânica participa, ainda, do processo de precipitação carbonätica pela reação dos produtos amoniacais, liberados após a morte dos animais, com os sais em dissolução, como: 


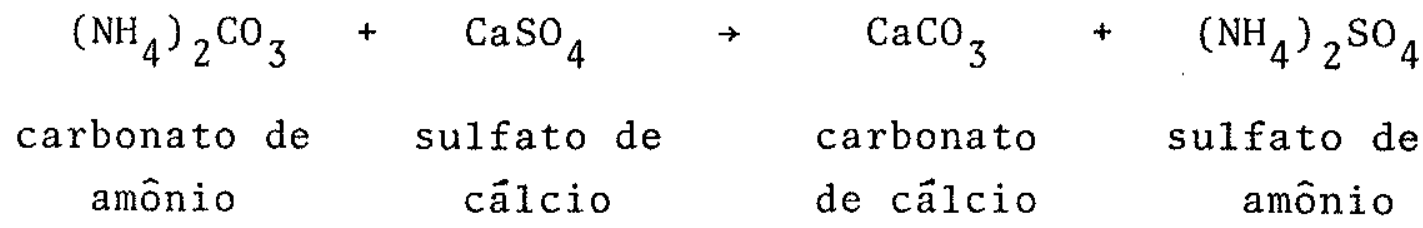

ou pela alteração do pH (MASON, 1971; KRAUSKOPF, 1972).

Em vista dos agentes físicos e químicos que favorecem a precipitação de $\mathrm{CaCO}_{3}$, as espécies animais que elaboram esse composto preferem as äguas têpidas equatoriais, onde $\vec{e}$ mais fácil a absorção e manutenção do cälcio em seus esqueletos e conchas. Daí a maior incidência de calcários corresponder às zonas de baixas latitudes ao redor da Terra. Entretanto, mesmo para essas zonas hä limites de profundidade para a formação de rochas carbonáticas.

A profundidade na qual a velocidade de precipitação de carbonato de cálcio é igual à velocidade de dissolução, chamada profundidade de compensação, não ultrapassa 3.500 metros. Abaixo dela ocorre dissolução, devido aos elevados conteüdos de $\mathrm{CO}_{2}$, sustentados pelas altas pressões e baixas temperaturas (Figura 5). Alëm da incapacidade de penetração dos raios solares, as baixas temperaturas das profundezas oceânicas são devidas às correntes polares em direção ao Equador, em sentido contrário ao das correntes superficiais, do Equador para os Polos.

Para Howenstaḿ (LAPORTE, 1975) a precipitação de carbonato de cálcio, sob a forma de calcita ou de aragonita, depende da temperatura. Em geral, as espëcies que segregam somente aragonita são de äguas quentes e as espëcies que segregam tanto uma quanto outra mantêm proporções conforme a temperatura da ägua. As de águas frias apresentam altas relações calcita/aragonita, enquanto que as de äguas quentes mostram baixas relações entre as mesmas. 


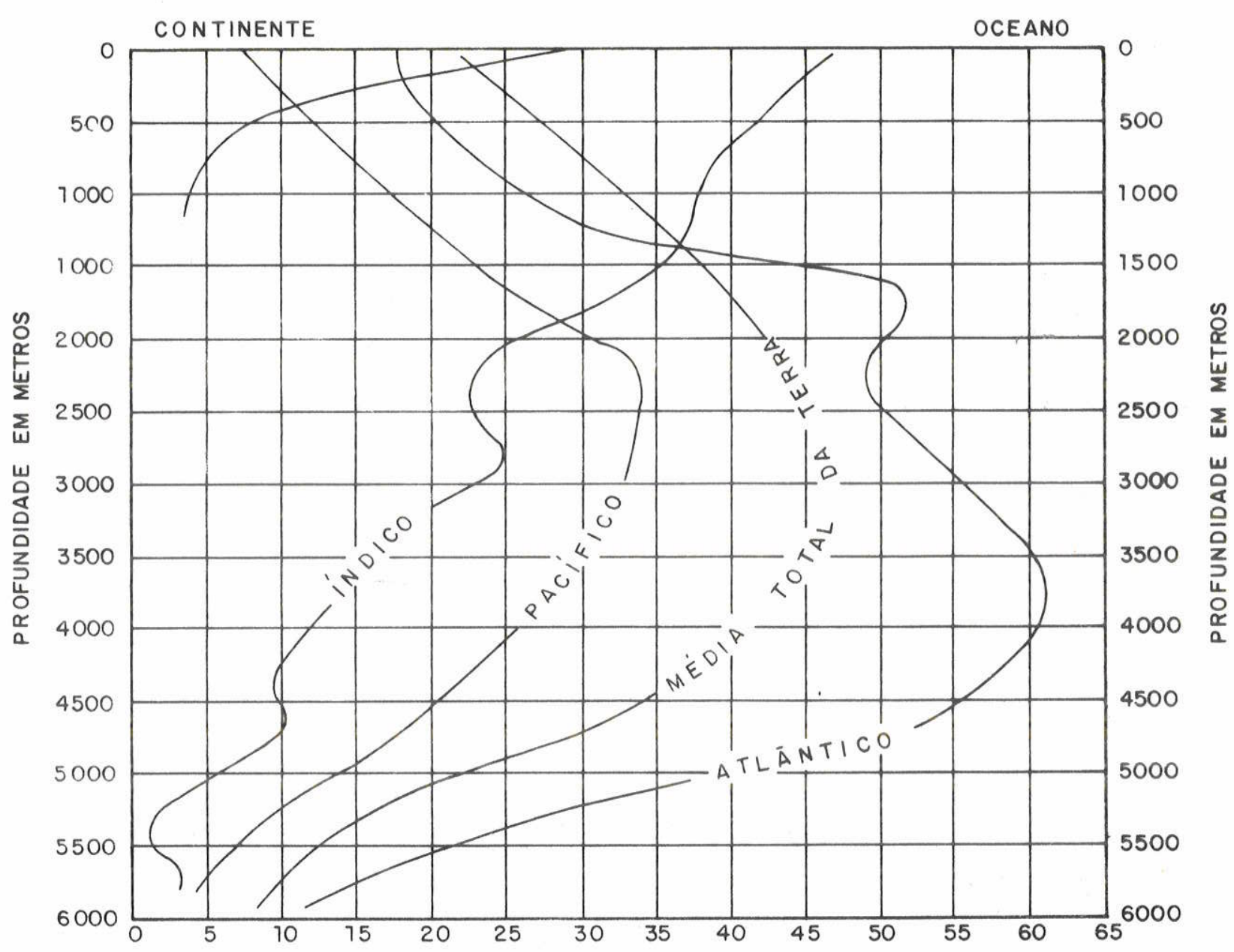

TEOR DE CAREONATO EM \%

TEMPERATURA EM ${ }^{\circ}$ (CURVA AO ALTO E A ESQUERDA)

Figura 5 - Correlação do conteúdo de calcário com a profundidade oceânica, segundo trabalhos de Sverdrup, em 1946, e de Küenen, em 1950, (BRINKMANN, 1964).

Para TUREKIAN (1969), a calcita, por sua vez, pode ser fracamente magnesiana, segregada por determinadas espécies de organismos.

Caso os carbonatos sejam redissolvidos, resultam lamas calcảrias, calcíticas ou aragoníticas, de difícil distinção quanto à origem orgânica ou inorgânica, sobretudo após a diagênese. Elas podem ser distintas pelo conteúdo de magnésio que, nos calcârios inorgânicos é inferior a $8 \%$ e nos orgânicos pode atingir 30\% (BRINKMANN, 1964). A aragonita tem menos de $1 \%$ de $\mathrm{MgCO}_{3}$. 


\section{3 - Geotectônica das Rochas Carbonāticas}

A formação de minerais e de rochas carbonāticas se dâ em condições específicas, criadas por fenômenos geológicos de grandes amplitudes no tempo e no espaço chamados movimentos tectônicos. Os movimentos tectônicos têm origem profunda e produzem unidades estruturais da crosta, divididas em äreas de grande (geossinclinais) e de pequena mobilidade (plataformas). Os movimentos tectônicos podem ser de värias naturezas, de causas e efeitos distintos, classificados fundamentalmente em movimentos oscilatörios (verticais) e movimentos de dobramentos (horizontais).

Como efeitos dos movimentos tectônicos verticais ocorrem mudanças periődicas (movimentos oscilatörios) e gradativas no relevo e na extensão das partes soerguidas (continentes) e rebaixadas (oceanos) da crosta. As subsidências e os soerguimentos são compensados, respectivamente, por sedimentação e erosão, controladas por vârios agentes ainda não conhecidos, mas com caracterîsticas, que permitem definir as fases em que são formados värios tipos de rochas.

Em função das características físicas e quỉmicas dos sedimentos geossinclinais, depositados nas värias fases do movimento oscilatório, BELOUSSOV (1971) estabeleceu, em 1954, o conceito de sequência sedimentar. Como, em fases análogas de cada ciclo, repetem-se condições tectônicas similares, ocorre deposição de materiais parecidos.

Segundo esse autor, na primeira fase do ciclo forma-se a sequência terrígena inferior, representada por depósitos de areias e argilas, ricos em matēria orgânica. Em seguida, deposita-se a sequência carbonātica, representada por calcários, correspondente ao final da primeira metade do ciclo, precedente à inversão do movimento, atê então subsidente. Por isso, essa sequência tambëm ê conhecida por se- 
quência carbonatada de prë-inversão.

Com o soerguimento do geossinclinal inicia-se a deposição da sequência terrígena superior, resultante da erosão das partes ascencionais. Essa sequência tambēm é constituída de material clästico (areias e argilas), com grande quantidade de matêria orgânica, pela reaproximação da linha da praia (regressão). Ela culmina com o assoreamento total da bacia.

O ciclo do movimento oscilatório se completa com a sequência molāssica. Ela se inicia com depósitos evaporíticos e gradua para clästicos, até conglomerados.

O conceito de sequência sedimentar de BELOUSSOV estende o conceito de fäcie sedimentar de Gressly (KRUMBEIN \& SLOSS, 1963; DUNBAR \& RODGERS, 1966), puramente geogräfico, para o campo da geotectônica (Figura 6). Frente a complexidade mecânica dos movimentos oscilatórios, hả grande interdigitação dos sedimentos de cada uma de suas fases, de tal foram que cada sequência compreende um conjunto de fäcies.

Com a deposição da sequência terrígena superior é encerrado o ciclo do movimento oscilatório. Nessa fase, o soerguimento prevalece sobre a subsidência, surgindo, no 1ocal do geossinclinal, grandes cadeias de montanhas e os sedimentos são metamorfizados.

Das sequências sedimentares, ou das fäcies de sedimentação, somẹte a sequência carbonatada, ou a fäcie carbonatada ê pertinente ao tema desta dissertação. Sua deposição coincide com a paralização do movimento ascencional e a consequente cessação da erosão-sedimentação, que ocorre no final da primeira metade do ciclo, de máxima subsidência.

Ao mudar a dinâmica da movimentação da crosta, aș 


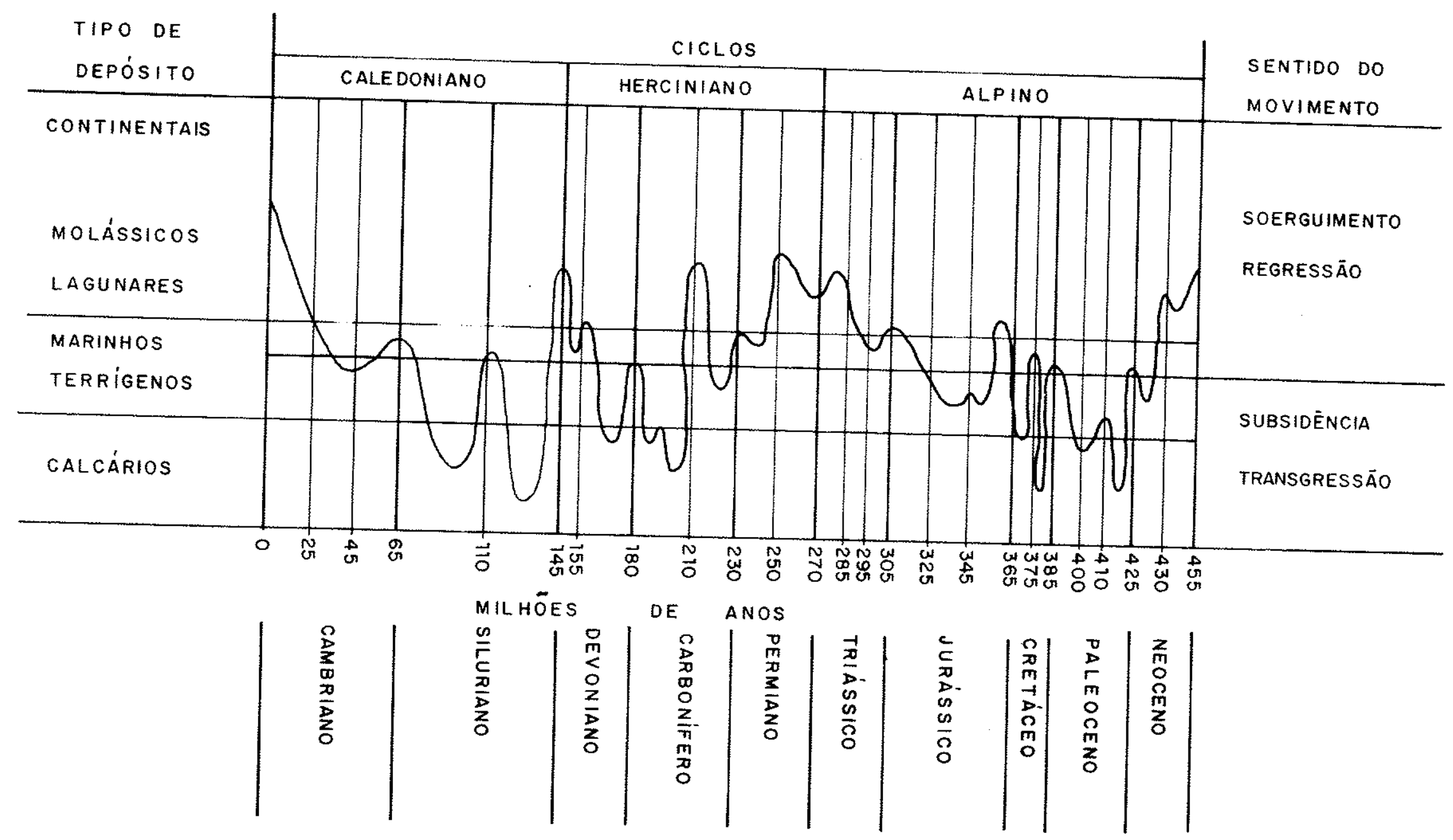

Figura 6 - Correlação da natureza física e química dos sedimentos geossinclinais com os movimentos tectônicos da Região Atlântica (BELOUSSOV, 1971). 
plataformas e os pacotes sedimentares dos geossinclinais $f \dot{x}-$ cam sujeitos à esforços horizontais de compressão (movimentos de dobramento), provocando deformações plästicas e recristalização dos sedimentos.

Além dos movimentos oscilatórios, produzidos por esforços verticais, ou tangenciais disjuntivos, e dos movimentos de dobramento, produzidos por esforços tangenciais compressivos, ocorrem movimentos de fraturamento, produzidos por esforços verticais sobre as porções rígidas da crosta. os movimentos de fraturamento quase sempre são associados a movimentos oscilatörios e de dobramento, aparecendo na segunda metade do ciclo, isto ê, apōs a inversão. Eles provocam rupturas, ao longo das quais pode haver, ou não, deslocamentos das partes (falhas e diaclases). As falhas, em geral, têm maior expressão geotectônica, principalmente as profundas que, no conceito estabelecido por Peyve (BELOUSOV, 1971), atravessam a crosta em toda a sua espessura, definindo as unidades estruturais denominadas blocos orogênicos.

Os movimentos tectônicos, ainda, são comumente acompanhados de atividade ígnea cujos produtos podem ficar alojados no interior da crosta (intrusivas), ou podem extravasar na superfície (extrusivas). Em qualquer caso, tais manifestações aparecem com a inversão do geossinclinal, associadas, portanto, às partes elevadas das faixas de dobramen-
to.

\section{4 - Petrologia das Rochas Carbonäticas}

Apōs a deposição, os sedimentos sofrem transformações de natureza e intensidade värias, para se adaptarem is novas condições reinantes. As transformações de altas pressões e temperaturas (metamörficas), ocorrem em continuidade às transformações de baixas pressões e temperaturas (diagenëticas), motivo pelo qual não existe limite nitido entre 
rochas sedimentares e metamórficas.

Em 1967, Enge1hardt (WINKLER, 1977) distinguiu rochas sedimentares de rochas metamórficas pela presença de fluidos aquosos, que se movimentam livremente atravês dos interstícios da rocha, promovendo reações do tipo de um sistema aberto. Para ele, o domínio sedimentar termina onde os espaços intercomunicáveis da rocha estiverem fechados, passando a prevalecer reações do tipo de sistema fechado.

WINKLER (1977) prefere estabelecer o limite sedimentar/metamörfico em termos mineralögicos, definindo o começo do metamorfismo pelo aparecimento de uma associação mineral que não pode existir em ambiente sedimentar. Apenas alguns tipos de rochas se prestam para definir esse limite. As rochas carbonāticas, por exemplo, não são adequadas, em vista da estabilidade da associação calcita-quartzo entre amplos intervalos de pressões e temperaturas.

Seja no domínio diagenëtico, seja no domínio metamörfico, a principal transformação experimentada pelos carbonatos $\vec{e}$ a recristalização. Em condições brandas, ocorrem apenas mudanças texturais, mas em condiçōes enērgicas ocorrem transformações minerais, por reações de descarbonatação, e estruturais, pelo desenvolvimento de descontinuidades no maciço rochoso (fraturas).

Rochas carbonäticas sedimentares são de ampla distribuição na crosta despertando o interêsse dos petrólogos. Elas têm ampla variação composicional entre três constituintes fundamentais $\mathrm{CaCO}_{3}, \mathrm{MgCO}_{3}$ e $\mathrm{SiO}_{2}$ (Figura 7), bastante estảveis entre largos intervalos de pressão e temperatura, mas particularmente sensiveis ao calor.

Os estudos de seu comportamento aos agentes metamörficos foram iniciados por Eskola, em 1922, e por Bowen, 


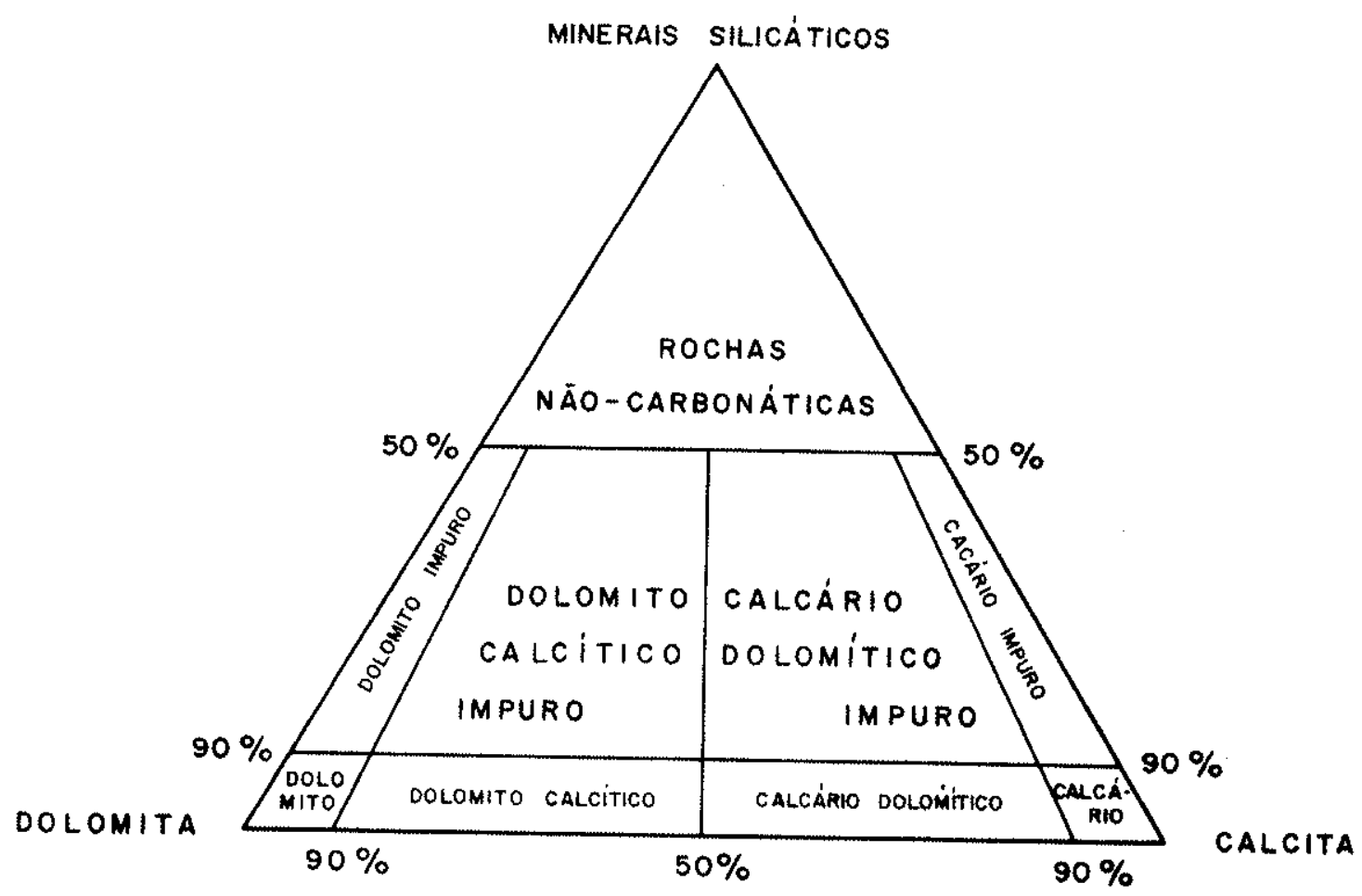

Figura 7 - A situação das rochas carbonäticas quanto à composição químico-mineralógica(CARR. \& ROONEY,1975)

em 1940 (WINKLER, 1977). Por ação do calor os carbonatos sofrem recristalização, favorecida pela fluidez do $\mathrm{CO}_{2}$ desprendido com o aquecimento, originando rochas mais grosseiras, granoblästicas. Alguma orientação apresentada é resquício de feições sedimentares.

o comportamento químico das rochas carbonaticas ao metamorfismo pode ser compreendido a partir de TURNER \& VERHOOGEN (1960), TURNER (1968), WILLIAMS, TURNER \& GILBERT (1970), MIYASHIRO (1975) e WINKLER (1977). Os principais aspectos a serem notados são:

- calcärios de $\mathrm{CaCO}_{3}$, puros, dão märmores calcíticos, simplesmente;

- calcärios dolomíticos, sem quartzo, têm seu 
$\mathrm{MgCO}_{3}$ decomposto pelo calor muito antes do $\mathrm{CaCO}_{3}$, segundo a reação:

$\underset{\text { dolomita }}{\operatorname{CaMg}\left(\mathrm{CO}_{3}\right)_{2}} \underset{\mathrm{PO}_{2} / \mathrm{H}_{2} \mathrm{O}=1 \text { kbar }}{\stackrel{700{ }^{\circ} \mathrm{C}-850{ }^{\circ} \mathrm{C}}{\mathrm{P}_{2}}} \underset{\text { calcita pericläsio gäs }}{\mathrm{CaCO}_{3}}+\underset{\mathrm{MgO}}{\mathrm{CO}_{2}}$

- caso haja quartzo, o início das transformações metamórficas $\vec{e}$ marcado pelo aparecimento do talco, através da equação:

$\left.3 \mathrm{CaMg}\left(\mathrm{CO}_{3}\right)_{2}+8 \mathrm{SiO}_{2}+\mathrm{H}_{2} \mathrm{O}+\mathrm{Mg}_{3} \mathrm{(OH}\right)_{2} / \mathrm{Si}_{8} \mathrm{O}_{22}+3 \mathrm{CaCO}_{3}+3 \mathrm{CO}_{2}$

dolomita quartzo ägua talco calcita gás

elevadas exibirä:

- mesmo material, sob pressões de $\mathrm{CO}_{2} / \mathrm{H}_{2} \mathrm{O}$ mais

$5 \mathrm{CaMg}\left(\mathrm{CO}_{3}\right)_{2}+8 \mathrm{SiO}_{2}+\mathrm{H}_{2} \mathrm{O}+\mathrm{Ca}_{2} \mathrm{Mg}_{5}(\mathrm{OH})_{2} / \mathrm{Si}_{8} \mathrm{O}_{22}+3 \mathrm{CaCO}_{3}+7 \mathrm{CO}_{2}$

clolomita quartzo ägua tremolita calcita gäs

transformações essas, tîpicas das zonas mais externas das aurēolas de contato, que produzem rochas finas, com cristalização imperfeita;

- em temperaturas e pressões de $\mathrm{CO}_{2} / \mathrm{H}_{2} \mathrm{O}$ crescentes ocorre a seguinte sequência de reações:

$$
\begin{aligned}
& \mathrm{Ca}_{2} \mathrm{Mg}_{5}(\mathrm{OH})_{2} \mathrm{Si}_{8} \mathrm{O}_{22}+3 \mathrm{CaCO}_{3}+{ }_{10 \mathrm{SiO}_{2}}+5 \mathrm{CaMgSi}_{2} \mathrm{O}_{6}+3 \mathrm{CO}_{2}+\mathrm{H}_{2} \mathrm{O} \\
& \text { tromolita calcita quartzo diopsídio gás ảgua } \\
& \mathrm{Mg}_{3}(\mathrm{OH})_{2} / \mathrm{Si}_{4} \mathrm{O}_{10}+5 \mathrm{CaMg}(\mathrm{CO})_{2} \rightarrow 4 \mathrm{Mg}_{2} \mathrm{SiO}_{4}+5 \mathrm{CO}_{2}+5 \mathrm{CaCO}_{3} \\
& \text { talco dolomita forsterita gâs calcita }
\end{aligned}
$$

$\mathrm{Ca}_{2} \mathrm{Mg}_{5}(\mathrm{OH})_{2} / \mathrm{Si}_{8} \mathrm{O}_{22}+11 \mathrm{CaMg}\left(\mathrm{CO}_{3}\right)_{2} \rightarrow 8 \mathrm{Mg}_{2} \mathrm{SiO}_{4}+13 \mathrm{CaCO}_{3}+9 \mathrm{CO}_{2}+\mathrm{H}_{2} \mathrm{O}$

tremolita dolomita forsterita calcita gäs ägua 
- nos meios anidros, a sequência de reações, com a temperatura, é:

$$
\begin{aligned}
& \mathrm{CaMg}\left(\mathrm{CO}_{3}\right)_{2}+2 \mathrm{SiO}_{8} \rightarrow \mathrm{CaMgSi}_{2} \mathrm{O}_{6}+2 \mathrm{CO}_{2} \\
& \text { dolomita quartzo diopsîdio gās }
\end{aligned}
$$

$$
\begin{aligned}
& \mathrm{CaMgSi}_{2} \mathrm{O}_{6}+3 \mathrm{CaMg}\left(\mathrm{CO}_{3}\right)_{2} \rightarrow 2 \mathrm{Mg}_{2} \mathrm{SiO}_{4}+4 \mathrm{CaCO}_{3}+2 \mathrm{CO}_{2} \\
& \text { diopsidio dolomita forsterita calcita gäs }
\end{aligned}
$$

$$
\underset{\mathrm{CaCO}_{3}}{\text { calcita quartzo }}+\underset{\mathrm{SiO}_{2}}{\mathrm{CaSiO}_{3}}+\mathrm{CO}_{2}
$$

- sob temperaturas crescentes, calcärios com impurezas de $\mathrm{Al}_{2} \mathrm{O}_{3}$ dão origem à epídoto, hornblenda e plagioclảsio cảlcico, e calcários com $\mathrm{K}_{2} \mathrm{O}$ originam muscovita, flogopita e feldspato $K$;

- os minerais-indices de graus metamörficos crescentes são talco, tremolita, diopsídio e wollastonita.

Para exemplificar seu conceito de paragênese metamórfica, WINKLER (1977) cita o caso de um calcärio silicoso, metamorfizado à pequena profundidade e alta temperatura, em que ocorre a formação de wollastonita e desprendimento de $\mathrm{CO}_{2}$. Em condições de equilíbrio as três fases sólidas (calcita-quartzo-wollastonita) coexistem com a fase gasosa. Porëm se o equilibrio for ultrapassado, dependendo do excesso de calcita ou de quartzo, no sedimento, ocorrerá a paragênese wollastonita-calcita ou wollastonita-quartzo, respectivamente, na rocha metamórfica.

Outro exemplo citado por WINKLER (1977) $\overrightarrow{\mathrm{e}}$ o caso de um märmore à calcita-dolomita-tremolita-talco-quartzo. Se todos esses minerais constituirem uma só paragênese significa que a rocha foi formada em condições isobäricas inva- 
riantes. Porẻm, caso ocorra a associação talco-dolomita-calcita a rocha se cristalizou nas partes do corpo de calcário dolomîtico silicoso onde predominava dolomita. Caso ocorra tremolita-talco-calcita a rocha resultou de porções de composição intermediāria, ou tremolita-calcita a rocha foi formada em äreas de excesso de sîlica.

Existem inümeras classificações das rochas carbonäticas, fundamentadas nos conteūdos de $\mathrm{Ca}$ e $\mathrm{Mg}$, ou no conteüdo de calcita e dolomita (Quadro 15, Figura 7). Sua extensão aos märmores é feita com a manutenção dos adjetivos calcïtico", "dolomítico" e, às vezes "magnesítico". Para cantaria, tais características não têm importância, a não ser para aproveitamento dos subprodutos do afeiçoamento da pedra.

\section{5 - Estägios Geolögicos das Rochas Carbonäticas}

0 conhecimento da geologia das rochas carbonäticas e das maneiras como elas ocorrem na natureza são importantes para o estabelecimento dos métodos para sua classificação, prospecção e qualificação, visando a utilização na construção civil.

0 primeiro estägio da existência dos carbonatos, na crosta, é sob a forma de sedimentos. Eles podem ser de origem quîmica, ou mecânica, orgânica ou inorgânica caracterizados pela natureza lamacenta, essencialmente inconsolidados. Quando de origem inorgânica, conforme proposto por Folk, em 1959, são chamados micrita. São constituídas de microcristais (diâmetros menores que $0,05 \mathrm{~mm}$ ) de calcita e aragonita, em densa imersão aquosa ( $80 \%$ de $\left.\mathrm{H}_{2} \mathrm{O}\right)$ e porosidade entre $50 \%$ e $60 \%$ (CHILINGAR, BISSEL \& FAIRBRIDGE, 1967). Em 1962, LEIGHTON \& PENDEXTER fixaram as dimensões micríticas abaixo de $0,03 \mathrm{~mm}$ a partir do que o termo tem sido usado para adjetivar calcärios e dolomitos (BISSEL \& CHILINGAR,1967; 


\begin{tabular}{|c|c|c|c|c|c|c|c|c|c|c|c|c|}
\hline & & QUAL & $15-$ & LASSIFIC & XO DAS & ROCHAS & CARBONXT & ICAS SEDI & MENTARES & & & \\
\hline \multirow{3}{*}{ MAT:RIR: } & \multicolumn{8}{|c|}{ conteudo em : } & \multirow{3}{*}{$\frac{\mathrm{CaO} / \mathrm{MgO}}{(2)}$} & \multirow{3}{*}{$\frac{\mathrm{Ca} / \mathrm{Mg}}{(4)}$} & \multirow{3}{*}{$\begin{array}{c}\mathrm{CaO} / \mathrm{MgO} \\
(5)\end{array}$} & \multirow{3}{*}{$\frac{\begin{array}{c}\text { Equiv. Mg } \\
(i)\end{array}}{(5)}$} \\
\hline & \multicolumn{3}{|c|}{ dolomita } & \multicolumn{3}{|c|}{ calcita } & \multirow{2}{*}{$\frac{\text { argila }}{(1)}$} & \multirow{2}{*}{$\frac{\text { magnesita }}{(2)}$} & & & & \\
\hline & (1) & (2) & (3) & (1) & (2) & (3) & & & & & & \\
\hline cỉlcário calcítico & $0-5$ & $5-0$ & $<5$ & $100-90$ & $95-100$ & $>95$ & $0-5$ & - & $>50,1$ & $>105$ & $0,00-0,02$ & $0,0-0,1$ \\
\hline culcário jưuco argiloso & $0-5$ & - & - & $95-85$ & - & - & $5-10$ & - & - & - & - & - \\
\hline calcário argilcso & $0-45$ & - & - & $35-90$ & - & - & 3010 & - & - & - & - & - \\
\hline $\begin{array}{l}\text { calcärio dolomítico } \\
\text { [ŕnuco argíloso }\end{array}$ & $5-47,5$ & - & - & $90-45$ & $75-95$ & - & $5-10$ & - & - & - & & \\
\hline $\begin{array}{l}\text { calcärio pouco } \\
\text { d:loníticu( } 6)\end{array}$ & $5-20$ & $25-5$ & $5-10$ & $95-80$ & - & $90-95$ & $0-5$ & - & $9,1-50,1$ & $60-105$ & $0,02-0,08$ & $1,1-4,3$ \\
\hline cslcârio dolomitico & $15-35$ & $50-25$ & $10-50$ & $80-65$ & $50-75$ & $50-90$ & $0-5$ & - & $4,0-9,1$ & $16-60$ & $0,08-0,25$ & $4,3-10,5$ \\
\hline $\begin{array}{l}\text { calcário muito } \\
\text { dolomítico }\end{array}$ & $30-50$ & - & - & $65-47,5$ & - & - & $0-5$ & - & - & $4,74-16$ & - & - \\
\hline $\begin{array}{l}\text { dolornito muito } \\
\text { calcítico }\end{array}$ & $65-47,5$ & - & - & $30-50$ & - & - & $0-5$ & - & - & - & $0,25-0,56$ & $10,5-19,1$ \\
\hline 3olonito calcítico & $80-65$ & $75-50$ & $50-90$ & $15-35$ & $25-50$ & $10-5$ & $0-5$ & - & $2,2-4,0$ & - & - & - \\
\hline $\begin{array}{l}\text { d)lomito pouco } \\
\text { calcítico }\end{array}$ & $95-80$ & $95-75$ & - & $5-20$ & $5-25$ & - & $0-5$ & - & $1,5-2,2$ & - & - & - \\
\hline $\begin{array}{l}\text { dolomi to calcítico } \\
\text { fzuco argiloso }\end{array}$ & $90-45$ & - & - & $5-47,5$ & - & - & $5-10$ & - & - & - & - & - \\
\hline $\begin{array}{l}\text { dalomi to pouco } \\
\text { argiloso }\end{array}$ & $95-85$ & - & - & $0-5$ & - & - & $5-10$ & - & - & - & - & - \\
\hline djlomi to argiloso & $35-90$ & - & - & $0-45$ & - & - & $30-10$ & - & - & - & $0,56-0,72$ & $19,1-22,0$ \\
\hline blomi to & $90-100$ & $100-95$ & $>90$ & $0-5$ & $0-5$ & $<10$ & $0-5$ & - & $1,4-1,5$ & - & - & - \\
\hline $\begin{array}{l}\text { loni to muito } \\
\text { cuco magnesiano }\end{array}$ & - & $100-95$ & - & - & - & - & - & $0-5$ & $1,25-1,4$ & - & - & - \\
\hline $\begin{array}{l}\text { Jlomi to pouco } \\
\text { aguesiano }\end{array}$ & - & $95-75$ & - & - & - & - & - & $5-25$ & $0,80-1,25$ & - & - & - \\
\hline Jomi to magnesiano & - & $75-50$ & - & - & - & - & - & $25-50$ & $0,44-0,80$ & - & - & - \\
\hline agnesito dolomítico & - & $50-25$ & - & - & - & - & - & $50-75$ & $0,18-0,44$ & - & - & - \\
\hline $\begin{array}{l}\text { agnesito pouco } \\
\text { Jomítico }\end{array}$ & - & $25-5$ & - & - & - & - & - & $75-95$ & $0,03-0,18$ & - & - & - \\
\hline agnesito & - & $5-0$ & - & - & - & $=$ & - & $95-100$ & $0,00-0,03$ & - & - & - \\
\hline
\end{tabular}

(1) Segundo Teodorovich, em 1958 (CHILINGAR, BISSEL \& FAIRBRIDGE, 1967) :

(2) segundo Frolova, em 1959 (CHILINGAR, BISSEL \& FAIRBRIDGE, (1967) .

(3) segundo Cayeux, wem 1935 (CHILINGAR, BISSEL \& FAIRBRIDGE,
1967) (4) segundo Chilingar, em 1957 (CHILINGAR, BISSEL \& FAIRBRIDGE,
1967).

(5) segundo Bigare11a, em 1956 (SINTONI \& VALVERDE, 1978).

(6) os calcários pouco dolomíticos também chamados de calcärios magnesianos, não apresentam dolomita, os ätomos de magnêsio estão dispersos nas redes cristalinas das calci tas. 
CARR \& ROONEY, 1975).

Vastos depósitos de sedimentos carbonảticos são formados, tambêm, pela acumulação de restos orgânicos,sintetizados por reações bioquímicas. Esses depósitos são chamados vasas, caracterizados pela natureza fragmentāria, em ampla variedade granulométrica.

A desidratação das lamas carbonảticas dả origem a um sedimento pulverulento, macio, poroso, chamado giz ou greda .

Por diagênese, os sedimentos carbonảticos, químicos e orgânicos, são transformados em calcảrios ou dolomitos, e suas variedades, isto $\vec{e}$, em rochas sedimentares. Esses materiais podem ser considerados como de um outro estágio,caracterizados pela consolidação. Como a consolidação se dá por cimentação, compactação e/ou recristalização, essas rochas apresentam graus de porosidade(da ordem de $10 \%$ ) e de umidade menores que os do estägio anterior. Sua porcentagem de aragonita ê praticamente nula,são foscas, de granulação fina, e relativamente pouco densas (CHILINGAR, BISSEL \& FAIRBRIDGE, 1967). Como dito anteriormente, são típicas de bacias sedimentares. As rochas carbonäticas sedimentares são muito usadas como alvenaria, mas raramente são usadas como cantaria,devido aos seus baixos graus de cristalinidade e, portanto, baixas resistências aos esforços mecânicos.

A classificação física das rochas carbonáticas sedimentares, utilizada por inümeros estudiosos ê baseada na textura, com base fundamentalmente, no grau de cristalinidade e na proporção clảsticos/cimento. Secundariamente, säo consideradas a forma dos grãos e a porosidade.

Por metamorfismo rochas carbonäticas sedimentares dão origem a mármores. Essas rochas são caracterizadas pela baixa porosidade, maior densidade, elevado grau de cristalização, granulação grosseira e cintilância, devido ao reflexo da luz nos planos de clivagem da calcita e/ou dolomita. São tîpicas dos cinturões orogênicos. No Brasil elas ocorrem 
frequentemente nas faixas de dobramentos (ALMEIDA, 1967 e 1968; MUSSA \& MOÇO, 1974; LOCZY \& LADEIRA, 1976; HASUI, ALMEIDA \& NEVES, 1978), em corpos de värias atitudes e vârios graus de perturbação.

\section{6 - Prospecção de Rochas Carbonäticas para Cantaria}

A prospecção de rochas carbonāticas para cantaria obedece aos mesmos critérios empregados para a maioria dos recursos minerais. Segundo a bibliografia corrente (BOWLES, 1939 ; CAVALCANTI, 1951; PICHLER, 1951; CURRIER, 1960 ;MENDES, 1974; POWER, 1975; AZAMBUJA \& SILVA, 1977; LADEIRA, 1977), compreende investigações geológicas, petrogräficas e econômicas (Quadro 16). Como o emprego das rochas em cantaria é feito na forma maciça, é preciso conduzir as pesquisas, sem destrui-las.

As investigações geolögicas compreendem todos os mêtodos que levem à caracterização do jazimento, quanto à forma, tamanho, posição, cobertura regolitica, intensidade e atitude do fraturamento, nivel freätico. Elas incluem,principalmente, aerofotogeologia, caminhamentos, escavação de poços e trincheiras, abertura de galerias, sondagens, que fornecem diferentes informações, em värios graus de precisão e de custo.

A aerofotogeologia é executada segundo os princípios da aerofotogrametria e interpretação geolögica (RAY, 1963; RICCI \& PETRI, 1965; LIBAULT, 1975), fornecendo os grandes traços 1itológicos e estruturais da região,importantes para a escolha da ärea a ser prospectada e para a orientação das pesquisas de detalhe.

Como base para lançamento, correlação e interpretação dos dados a serem levantados nos caminhamentos, escava- 


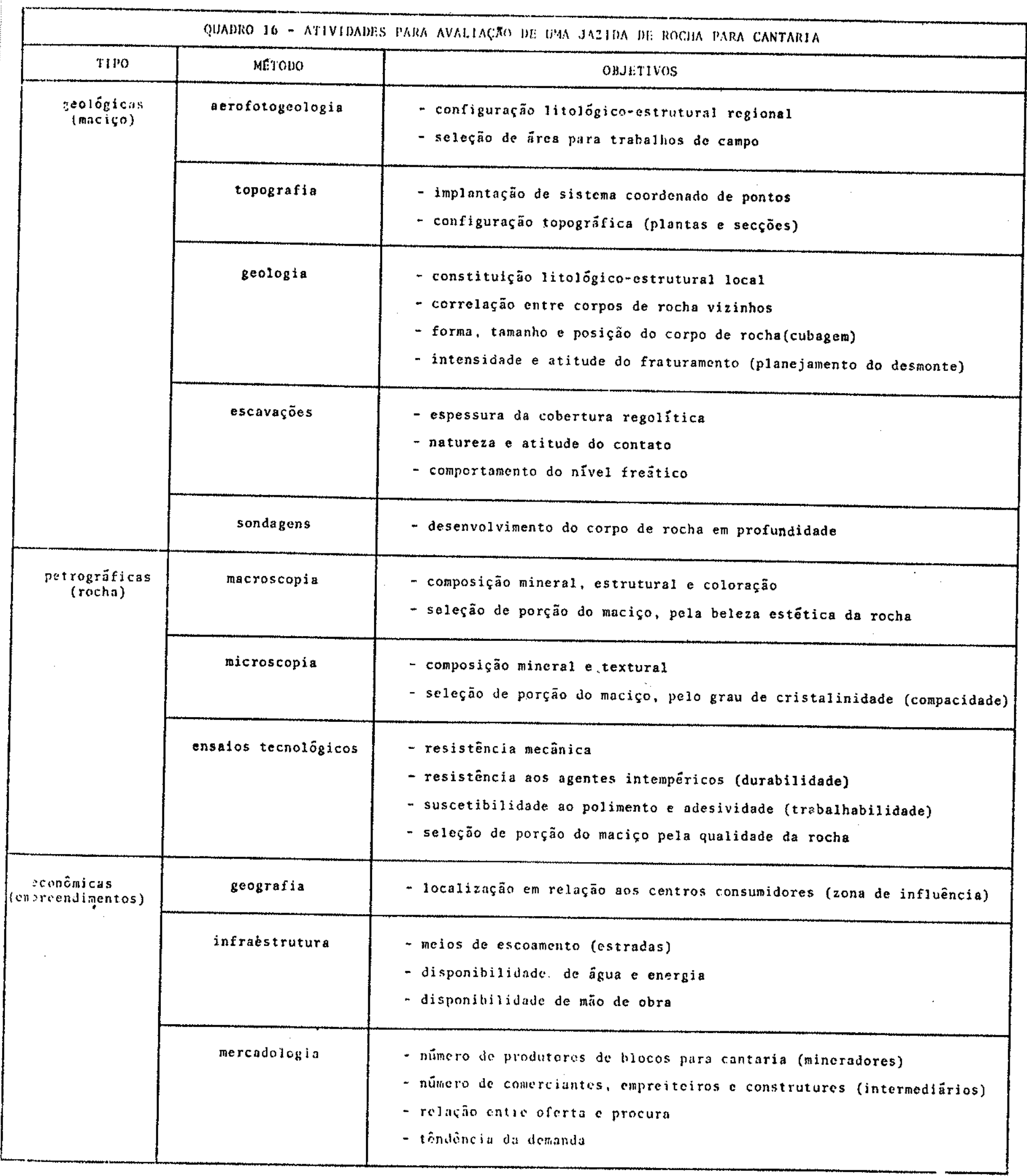


ções e sondagens, deve ser implantada, no terreno, uma malha regular de pontos, e ser desenhada, em planta e seções, a configuração topogräfica do local. As direções do sistema coordenado de pontos deve ser perpendicular às estruturas.

Os caminhamentos são executados sobre a maior extensão possível de exposição de rocha. Os afloramentos são tanto mais apropriados para exames quanto mais extensos e mais salientes na topografia. Deles são tirados os tipos de rocha a nível de distribuição e de variações minerảlógicas, texturais e de coloração, naquilo que os recursos da macroscopia permitirem.

Da integração dos dados dos caminhamentos com os dados da interpretação aerofotogeológica, nasce a expressão litológica superficial do corpo de rocha, importante para a scleção das porções a serem investigadas em detalhe, em termos de beleza da rocha. As porções que não apresentarem essa qualidade poderão ser aproveitadas nas indústrias de transformação, em função de sua natureza química.

A definição do tamanho do corpo de rocha depende, ainda, do conhecimento de seu desenvolvimento em profundidade. A ordem de grandeza desse parâmetro pode ser inferida da natureza (brusca, com ou sem deslocamento das partes, ou gradativa) e da atitude (direção, sentido c ângulo de mergu1ho) do contato com os corpos de rocha vizinhos. A profundidade real do corpo ê determinada por meio de sondagens rotativas. Trata-se, no entanto, de um método de prospecção mais empregado para verificação das variações químicas da rocha, visando sua aplicação nas indústrias de transformação.

A definição completa da morfologia do maciço rochoso compreende a identificação da situação topogräfica, em vale ou em crista.Essa feição depende da evolução geomorfológica da região, resultante da interação entre a consti- 
tuição litológico-estrutural e o regime climātico, importante para a interpretação dos condicionantes do aproveitamento do depósito. A topografia do local determina o estilo de extração da pedra, seja em cava ou em frente, para o que deve ser conhecido o comportamento do nível freático.

Quando a cobertura regolítica impedir a observação direta da rocha sã, ou do contato, são executados poços c trincheiras. Em geral, essas escavações não ultrapassam 3 metros de profundidade, em locais com declividades inferiores a $30^{\circ}-45^{\circ}$. A medida que a profundidade aumenta, sua exccução torna-se gradativamente impraticâve1. Então, os poços dão lugar às sondagens a trado e as trincheiras dão lugar às galerias. Enquanto os poços permitem observar a rocha produnda, os furos de trado fornecem, apenas, a espessura do regolito. As galerias, por outro lado, avançam maciço adentro quanto se queira, mas com a desvantagem do fissuramento que os explosivos podem provocar.

A influência da cobertura regolítica nos empreendimentos mineiros é tanto mais negativa quanto mais espessa e menor valor do minério. Assim, ela é mais inconveniente para as jazidas de rochas para construção que para as jazidas metálicas. Entre as jazidas de rocha para construção, ela $\vec{e}$ mais crítica para as de brita e alvenaria que para as de cantaria.

Os poços são utilizados tambêm para verificação do nîvel freătico. Quando eles não forem suficientes executam- se sondagens à percussão para instalação de piezômetros.

Das atividades geológicas, a maior contribuição para a caracterização do jazimento ê o levantamento de dados sobre a atitude e intensidade de fraturas. 0 profundo conhecimento do fraturamento $\vec{e}$ fundamental para cantaria, qualificando o maciço em termos de dimensões dos blocos e da 
resistência da rocha e minimizando os custos de produção.Para isso deve ser identificada a natureza (fissuras, diaclases, falhas, veios, bandas, acamamento, cavidade), a intensidade (número por unj.dade de extensão) e a atitude (direção, sentido, ângulo de mergulho) das estruturas. Os valores desses parâmetros, projetados estereograficamente em diagramas apropriados (BILLINGS, 1964; PHILLIPS, 1975; LOCZY \& LADEIRA, 1976), permitem identificar a atitude e a intensidade da estrutura predominante, para as vảrias partes do corpo.

As investigações geolögicas culminam com a cubagem de certa quantidade de material. Ao contrário de outras jazillas, em que reservas são avaliadas em toneladas, a cubagem las jazidas de rocha para cantaria deve ser expressa em metros cubicos ou em metros quadrados, a dimensão de seus produtos finais. Para os cälculos, Mlindes (1974, 1979 A e B) cstima que o rendimento da produção de blocos, nas pedreiras, seja da ordem de $70 \%$, e LYNZELL (1973) estima o rendimento no desdobramento dos blocos em placas da ordem de $60 \%$. Um outro dado importante para a cubagem de jazidas de rocha para cantaria o a média de $230 \mathrm{~m}^{2}$ de placas para cada $10 \mathrm{~m}^{3}$ de bloco. Esse valor varia pouco para mais ou para menos conforme a espessura das placas serradas, que podem ter $2 \mathrm{~cm}, 3 \mathrm{~cm}$ ou $4 \mathrm{~cm}$.

A metragem total de rocha a ser cubada sera função das características do mercado (capacidade de absorção da época e tendência futura), dos prazos de amortização do capital e de depreciação dos equipamentos envolvidos.

As atividades petrogräicas são iniciadas jă na raso do reconhecimento geológico, quando da identificação litolögica. Nessa ocasião são obscrvadas as variaçöes macroscopicamente notāveis, como textura, estrutura, composicão mineral, cor, porosidade, padrões de distribuição das 
impurezas, e é feita uma amostragem para exames microscópicos. Da correlação dos aspectos macro e microscópicos são obtidos os dados para seleção da porção do corpo de rocha,em termos de qualidade da pedra.

Como bem sugerem CARUSO, TAIOLI $\xi$

FARJALLAT

(1978), exames micropetrogräficos, na prospecção de rochas para cantaria, são de importância capital por revelarem detalhes não visíveis a olho nu, mas que podem ser altamente depreciativos por se manifestarem, apenas, depois da aplicação da rocha.

As investigações petrogräficas são seguidas da caracterização tecnolôgica da rocha. Ela compreende ensaios das variadas naturezas físicas, tais como porosidade, abrasividade, resistência à flexão, tração, compressão, segundo normas estabelecidas por värias instituições (BOWLES, 1939 ; PICHLER, 1942; CAVALCANTI, 1951; PICHLER, 1951; CURRIER, 1960; YOSHIDA, 1972; MENDES, 1974, 1979 A e B; PETRUCCI, 1974; WINKLER, 1975; CARUSO, TAIOLI \& FARJALLAT, 1978). Enquanto que as amostras para microscopia são menores, com volumes da ordem de centenas de centímetros củbicos, as amostras para os ensaios tecnológicos devem ter volumes da ordem de centenas de decímetros củbicos.

Além da qualidade e quantidade do material contido, a economicidade das jazidas de rochas para cantaria esta ligada a fatores geográficos e mercadológicos.

Os fatores geogräficos dizem respeito à 1ocalização da jazida em relação aos centros consumidores, como distância e infraestrutura. A proximidade geográfica dos centros de consumo ê um fator de importância vital para a viabilização dos empreendimentos, frente aos constantes aumentos dos combustíveis. A infraestrutura inclui a existência de meios de produção (mão de obra, ảgua, energia elétrica) e meios de escoamento (estradas). 
Os fatores mercadológicos dizem respeito à oferta e procura na região de influência da jazida, importantes para o dimensionamento da produção a ser absorvida e para definição do volume de rocha necessärio ao empreendimento.

A averiguação da economicidade de um empreendimento de cantaria é feita por levantamento das firmas que comercializam cantarias e suas fontes de suprimentos, da comparação dos preços na fonte e no local da obra e da capacidade regional de absorção dos produtos e subprodutos da mineração e beneficiamento da pedra. A capacidade regional de absorção dos produtos e subprodutos inclui fatores de a1ta subjetividade, como a preferência do pủblico, que consumirâ tanto mais conforme a moda.

Alẻm de uma terminologia clara para as peças das värias fases de produção das cantarias (Quadro 5), é preciso ter em mente que o mercado das cantarias é constituído pelo minerador, pelo intermediảrio (comerciante, empreiteiro, construtor) e pelo püblico. Enquanto o minerador ê responsảvel pela oferta, o intermediảrio é responsảvel pela procura e pela colocação do material junto ao público, com poderes de modificar hábitos e modismos. Assim, melhores resultados poderão ser conseguidos com habilidade do intermediārio atravês de ampla divulgação. e demonstração das vantagens sobre os substitutos. 
4. A JAZIDA DE MÄRMORE DE QUIXABA

\section{1 - Localização Geogräfica da Jazida}

A Jazida de Mármore de Quixaba está localizada no município de Pio IX, no extremo leste do Estado do Piauí, próxima às divisas com os Estados do Ceará e Pernambuco, aproximadamente a $40^{\circ} 30^{\prime} \mathrm{W}$ e $06^{\circ} 55^{\prime} \mathrm{S}$ (Figura 8). Ela está situada pröxima à junção das Folhas SB-24-Y-A-VI (Pio IX), $S B-24-Y-N-I V$ (AIUABA), SB-24-Y-C-III (FRONTEIRAS) e SB-24-Y-D-I (CAMPOS SALES), do Levantamento Cartogräfico do Brasil, na escala 1:100.000.

De Terezina, chega-se à Quixaba pela BR-116 (Belêm-Maceió), atê Picos, e pela BR-230 (João Pessoa-Rio Branco, ou Rodovia Transamazônica), atë Fronteiras, num total de $325 \mathrm{~km}$ asfaltados. De Fronteiras, toma-se a PI-229, que passa por Pio IX e Quixaba, para Campos Sales, jä no Cearä.

\section{2 - Fisiografia da Area}

Quixaba pertence à grande região fisiogräfica conhecida por Polígono das Secas, que compreende toda a região nordeste do Brasil, formada por inümeras micro-regiões restritas.

Em Quixaba, o clima $\vec{e}$ do tipo Bsh (K४ppen), quente e seco a semi-ärido, caracterizado por:

- regime de chuvas de verão (w), com precipitaçöes mëdias anuais inferiores a $800 \mathrm{~mm}$, distribuídas irregularmente entre novembro-dezembro e abril-maio;

- regime térmico bastante homogêneo (pequenas am- 


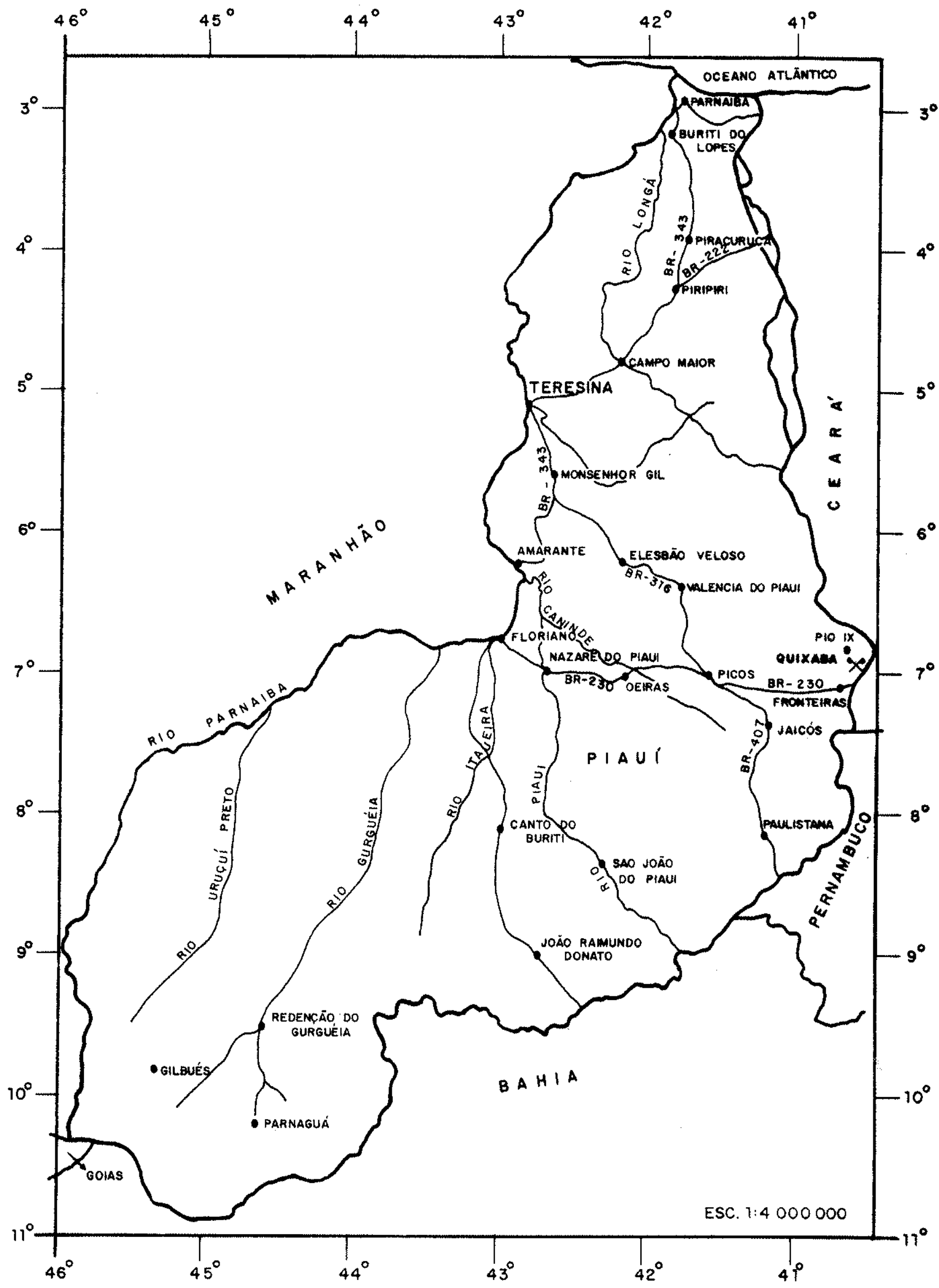

Figura 8 - Localização geogräfica da jazida de märmore de Quixaba. 
plitudes tërmicas anuais), com temperaturas máximas de $32{ }^{\circ} \mathrm{C}$ a $34{ }^{\circ} \mathrm{C}$, em setembro-outubro, e minimas de $19^{\circ} \mathrm{C}$ a $21^{\circ} \mathrm{C}, \quad$ em ju1ho;

- elevada insolação, entre $50 \%$ do dia, em fevereiro, a $80 \%$, em agosto;

- evaporação intensa, mảxima nos meses de setembro, outubro e novembro (CRUZ \& FRANÇA, 1971; OLIVEIRA, FORTLS, FERREIRA, GOMES \& LINS, 1974; FERREIRA \& BARROS, 1974).

A unidade botânica do Polígono das Secas é denominada Caatinga (do tupi-guaraní caa $=$ mata e tinga $=$ branca), correspondente à "steppe" de outras regiões do mundo, caracterizada pela vegetação xeröfita, escassa e rasteira, com abundância de cactāceas (Leocereus squamosus Geverke-Werd e bromeliảceas (Bromelia Zaciniosa Mart.). Conforme a natureza edäfica ocorrem variações locais, que JAPIASSU, VELOSO, GOES FILHO \& LEITE (1973) denominam arböreas ou arbustivas.

A região de Quixaba ẻ ocupada por uma dessas variações fitogeogräficas, em que predominam espēcimes de mêdio a grande porte como, jurema (Mimosa Spp), favela (Cnidosculus phylzacanthus Mue11. sag.), caatingueira (Caesalpina pyramidales Tul.), baraüna (Schinopsis brasiliensis ling1.), angico (Anadenanthera macrocarpa (Benth) Brenan), juazeiro (Zizyphus juazeiro Mart.), umbuzeiro (Spondia tuberosa e umburana (Bursera leptophocos).

Geomorfologicamente, segundo BARBOSA, BOAVENTURA ६̧ PINTO (1973), a ārea de Quixaba está localizada no extremo sul da Depressão Periférica de Crateús, separada da Depressão Periférica do Médio São Francisco por extensões residuais, para leste, dos sedimentos da Bacia do Parnaíba e, para oeste, da Chapada do Araripe (Figura 11). Com altitu-des médias de 300-400 metros, o rolevo foi originado por 
circundesnudação das formações sedimentares superiores, com a consequente exumação das rochas prë-devonianas dobradas, 1 igada à reativação geotectônica waldeniana (ALMEIDA, 1969).

Segundo os autores do Projeto Cococi (OLIVEIRA, FORTES, FERREIRA, GOMES \& LINS, 1974; OLIVEIRA \& BARROS, 1974) a região mostra dois níveis de erosão que formam duas grandes unidades geomorfológicas distintas.

Uma delas ë representada pelas chapadas paleo-mesozóicas. Pelos quadrantes nordeste e noroeste dominam os sedimentos paleozóicos da Bacia do Parnaíba e, pelo sul, os sedimentos cretảceos da Chapada do Araripe. Essas formações sedimentares estão alçadas na topografia, terminando em escarpas festonadas. Com desníveis mëdios de 300 metros, acima do embasamento, esses acidentes recebem nomes de serras. A escarpa da Bacia do Parnaíba, de direção geral N-S, é chamada regionalmente de Serra Grande (NUNES, LIMA \& BARROS, 1973; DANTAS, 1974 ).

A outra unidade geomorfológica, è constituída pelo embasamento cristalino. Quixaba pertence a ela e sua evolução geomorfológica estả relacionada à constituição 1ito- estrutural e ao processo de denudação da cobertura paleozóica, sob o clima ārido a semi-ārido do sertão nordestino.

Regionalmente, o relevo é pouco ondulado, representado por uma sequência paralela de cristas e vales alongados e alinhados, contínua por várias dezenas de quilômetros. lila resulta da erosão diferencial, segundo o acamamento pretérito, ora dobrado em "S" e verticalizado pelo tectonismo (Foto 1).

Localmente, o corpo de märmore de Quixaba ocupa um dos vales, onde despontam morros isolados, também alongados e alinhados, formados de rochas carbonáticas impuras 


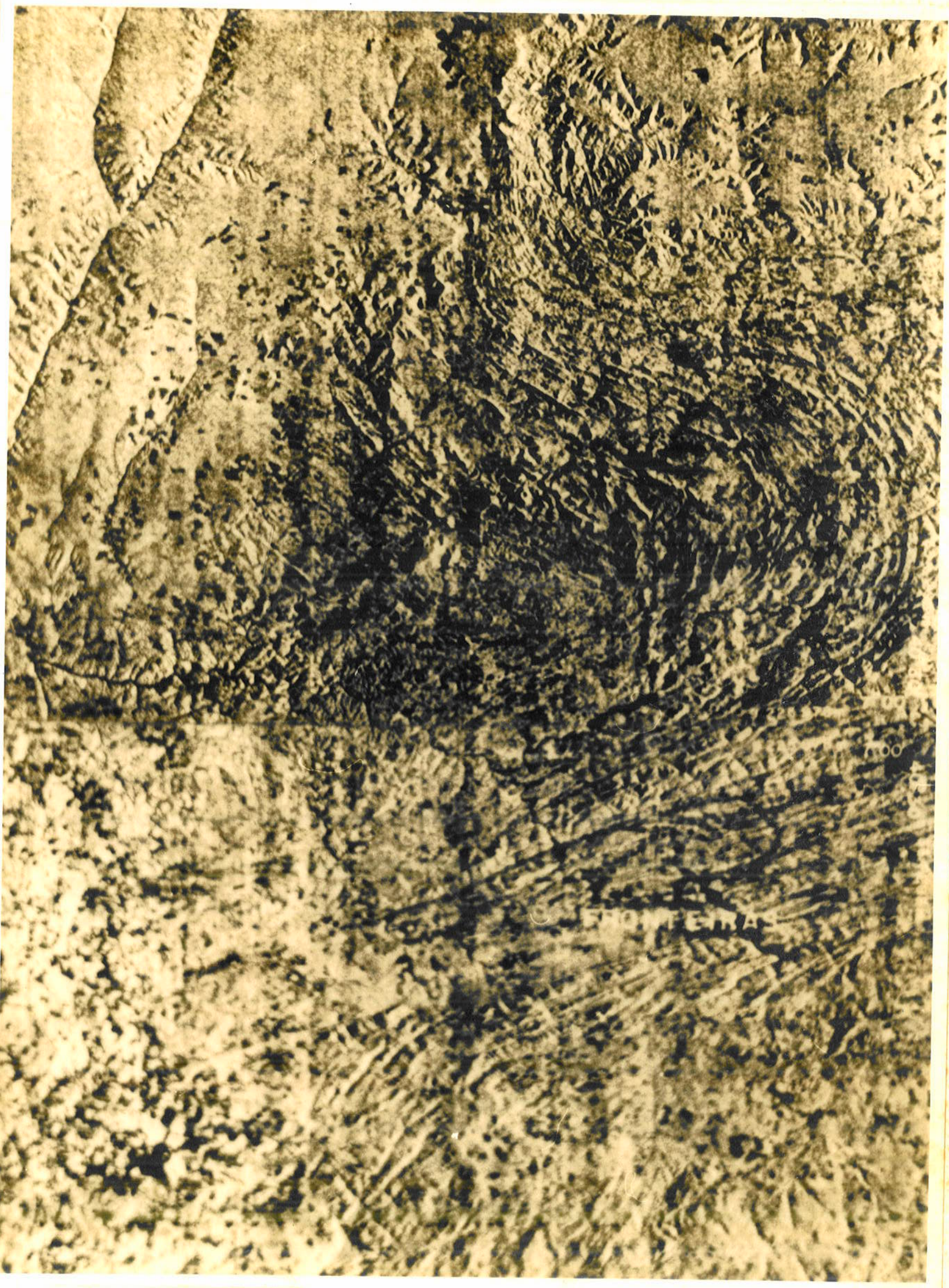

Foto 1 - Estrutura a que pertence a jazida de märmore 
(calcossilicatadas) que resistiram a erosão (Fotos 2 e 3 ).

Em Quixaba, cabe ressaltar ainda as feições carsticas. Destacam-se caneluras e dissoluções ao longo de fissuras que, juntamente com o aspecto da rocha, comprometem as primeiras impressões sobre o jazimento (Fotos 3 e 4 ).

Existem na região dois padrões de drenagem que se sobrepõem. 0 mais desenvolvido é caracterizado por vales abertos, desenvolvido segundo o acamamento, realçando a estrutura em "S". O outro é mais restrito, caracterizado por vales bastante encaixados, desenvolvido segundo fraturas tectônicas transversais ao acamamento e que interrompe a continuidade das cristas (Foto 1).

Sobre o cristalino, o solo é residual e pouco desenvolvido. Para os técnicos do Projeto Radam (NUNES, LIMA \& BARROS, 1973; SOMMER, ARAUJO, MARTINS \& CORREA, 1973) existe perfeito relacionamento entre unidades geomorfológicas e tipos de solo. Concordantes com essa afirmativa, os técnicos do Projeto Cococi (OLIVEIRA, FORTES, FERREIRA, GOMES \& BARROS, 1974; FERREIRA \& BARROS, 1974) dividem a formação regolítica da região em dois tipos: o das rochas silicảticas, arenoso, de coloração cinzenta, constiuídos de fragmentos de quartzo e feldspato, com ampla variação granulométrica; e o das rochas carbonāticas, argiloso de coloração avermelhada, mais desenvolvido que o primeiro. Sua espessura pode chegar a 3 metros enquanto que a do arenoso nunca u1trapassa 1 metro.

Nos leitos de drenagem, o solo é alóctone e constituído de material quartzo-feldspático fragmentärio grosseiro e mal selecionado, com espessura de alguns metros. Representa importante fonte potencial de material abrasivo para a produção e desdobramento dos blocos de märmore. 


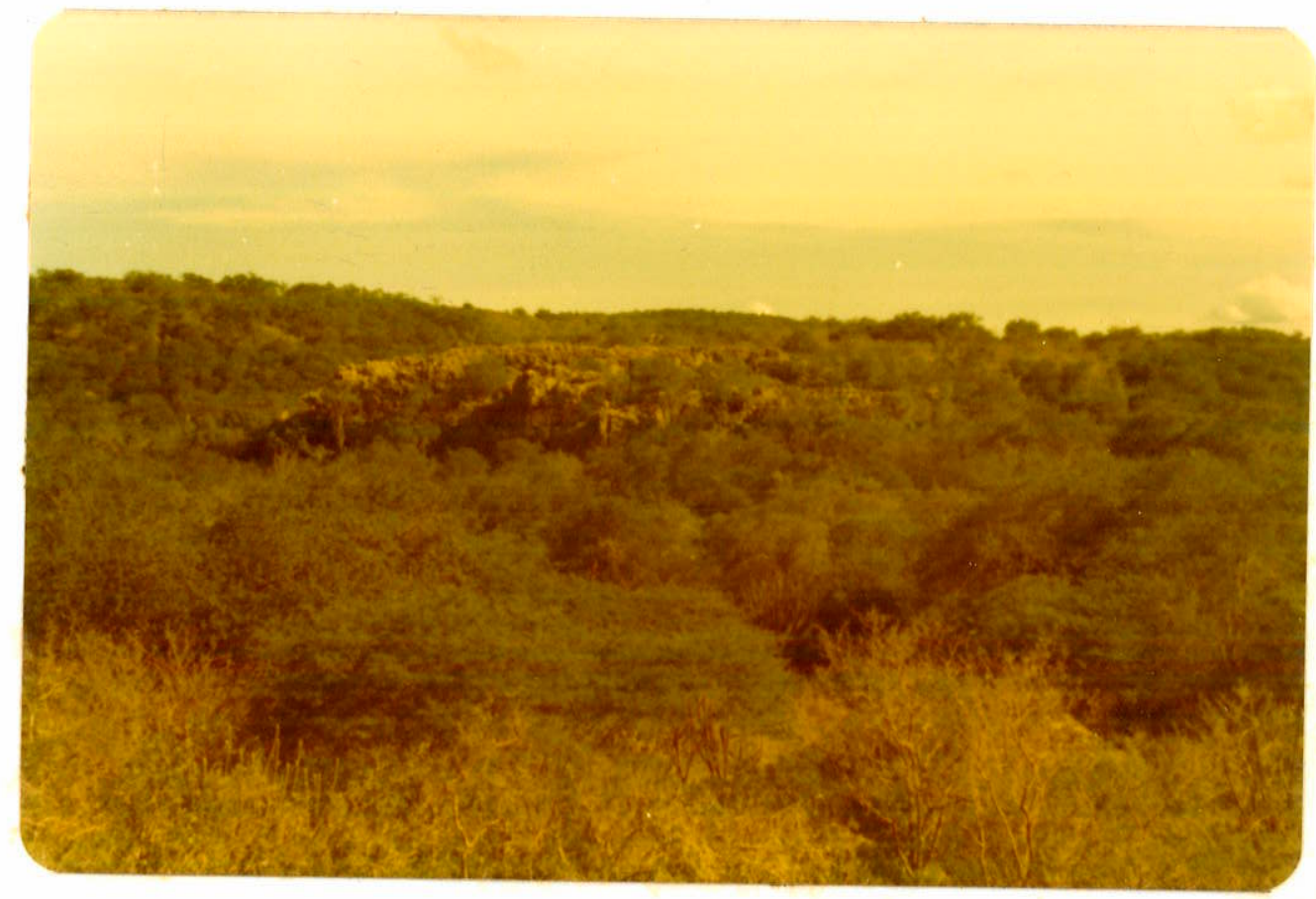

Foto 2 - Vista de uma das elevações de rochas carbonäticas impuras e fraturadas contra as rochas silicáticas.

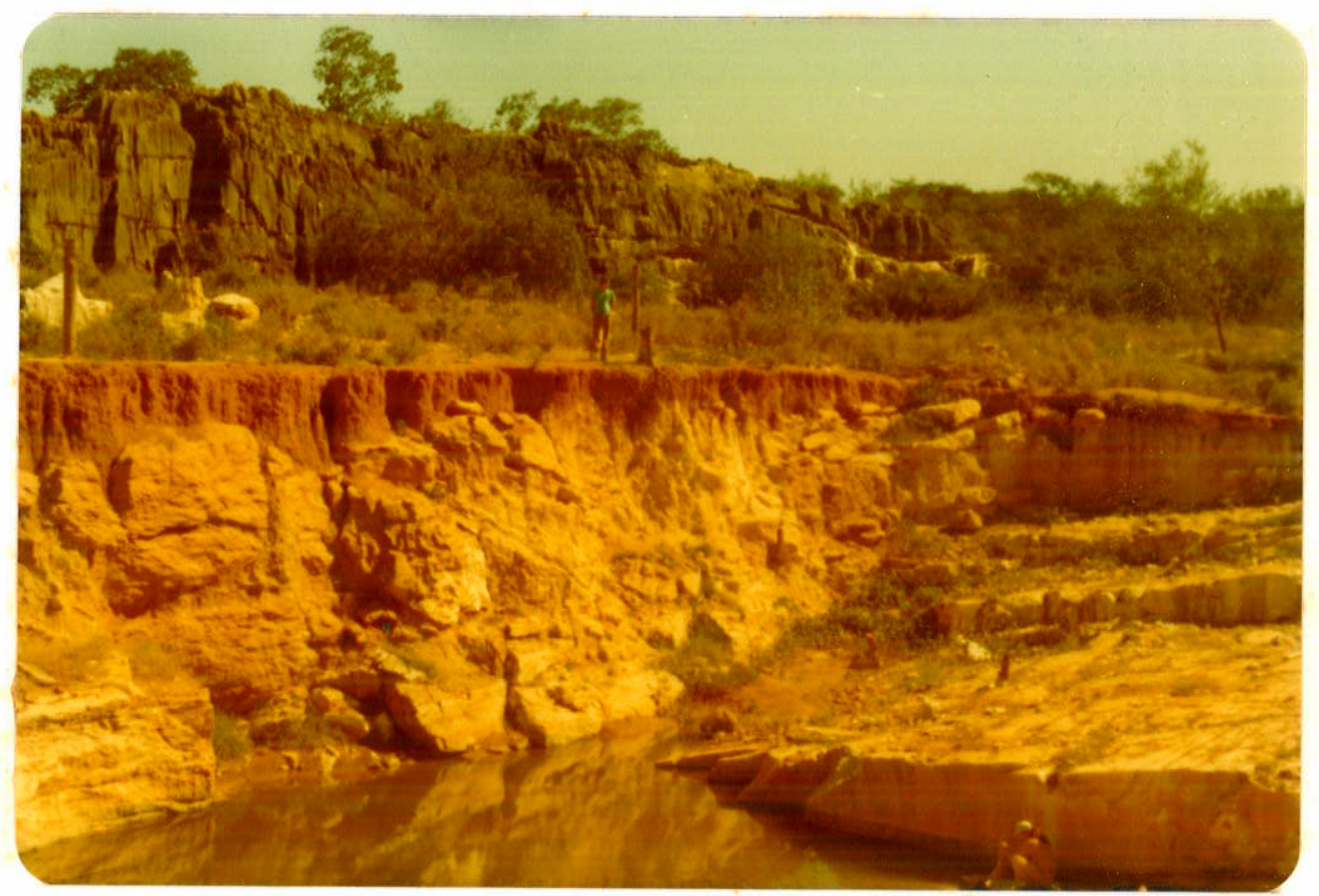

Foto 3 - Vista geral de uma frente de desmonte mostrando o flanco abrupto das elevações de märmore impuro e fraturado contra a porção de märmore branco e maciço coberto por solo avermelhado. 


\section{3 - Evolução dos Conhecimentos Sobre a Jazida de Quixaba}

Apesar de situada na ärea de värios estudos, desde o começo do século, a Jazida de Märmore de Quixaba ficou conhecida somente depois de 1969, quando algumas amostras de rochas foram encaminhadas à Divisão de Geologia, da Coordenação do Desenvolvimento do Estado do Piauí-CODESE.

Essa data representa um marco na evolução dos conhecimentos geológicos sobre a ärea, encerrando a fase dos reconhecimentos regionais, em escalas iguais ou maiores que 1:100.000, e inaugurando a fase dos levantamentos de detalhe, com escalas menores que 1:100.000.

Dentre os temas mais abordados pelos

programas

regionais estão a tectônica do embasamento cristalino e a es tratigrafia das bacias sedimentares. Quase sempre sem referências diretas ao sítio de Quixaba são, no entanto, importantes fontes de dados para o ajuizamento do depósito no contexto tectônico, estratigräfico e litológico global.

As primeiras idéias sobre as grandes direções estruturais do cristalino nordestino foram estabelecidas por Evans em 1903 (FREITAS, 1951; KEGEL, 1965). A KEGEL (1965) coube o estabelecimento dos blocos orogênicos do Nordeste. Segundo seu esquema, Quixaba estâ localizada no Bloco de Banabiü, delimitado por falhas direcionais SW-NE, recobertas pelos sedimentos da Bacia do Parnaíba, a oeste.

\section{Posteriormente SUSZCZYNSKI (1966) introduziu o} conceito de dorsais geoanticlinais e depressões laterais à tectônica do Nordeste. Separadas por grandes falhamentos da crosta, as depressões são constituídas de rochas de graus de metamorfismo mais baixos que as dos geoanticlinais. Segundo seu conceito, Quixaba estâ localizada na junção da Sé- 
rie Metamörfica do Cearả com a Sẻrie Metamörfica Independência-Sobra1.

Outro ensaio tectônico sobre a região foi apresentado por BEURLEN (1967). Para ele houve intensa movimentação durante o Cretảceo relacionada à abertura do At1ântico, com a qual apareceram as estruturas de direção E-W (Lineamento Patos) e SW-NE (Lineamento Sobra1-Pedro II), completamente diferentes das direções mais antigas, de direção N-S (Lineamento Espinhaço). O bloco compreendido entre os dois lineamentos citados, em cuja extremidade sudoeste está situada Quixaba, manteve-se estacionârio em relação aos vizinhos do sul e do norte, tendo sofrido intensa compressão(Figura 9).

ALMEIDA (1967, 1969), em seus trabalhos sobre a consolidação da plataforma brasileira, denominou o Nordeste do Brasil de Area de Dobramentos Caririanos referindo-se às sequências remobilizadas no Ciclo Brasiliano, hả 550 milhões de anos. Ela foi redenominada recentemente de Area de Dobramentos Nordeste (HASUI, ALMEIDA \& NEVES, 1978).

FERREIRA (1972) considerou a região onde se loca1iza Quixaba pertencente às Faixas de Dobramentos prë-Brasilianos, constituídas de granitóides de idade indeterminada.

NEVES (1975), baseando-se em conceitos anteriores de faixas de dobramentos e altos estruturais (NEVES, 1973), considera a região como produto da tectogênese do final do Precambriano, sobre uma ảrea geossinclinal em mosaico, como consequência da extensão dos dobramentos. De acordo com esse esquema, Quixaba está na Faixa de Dobramentos Jaguaribeana, subdividida à oeste na Subfaixa Rio Curu-Independência.

A intensa movimentação tectônica reconhecida por BEURLEN (1967) está sendo modernamente interpretada com ba- 


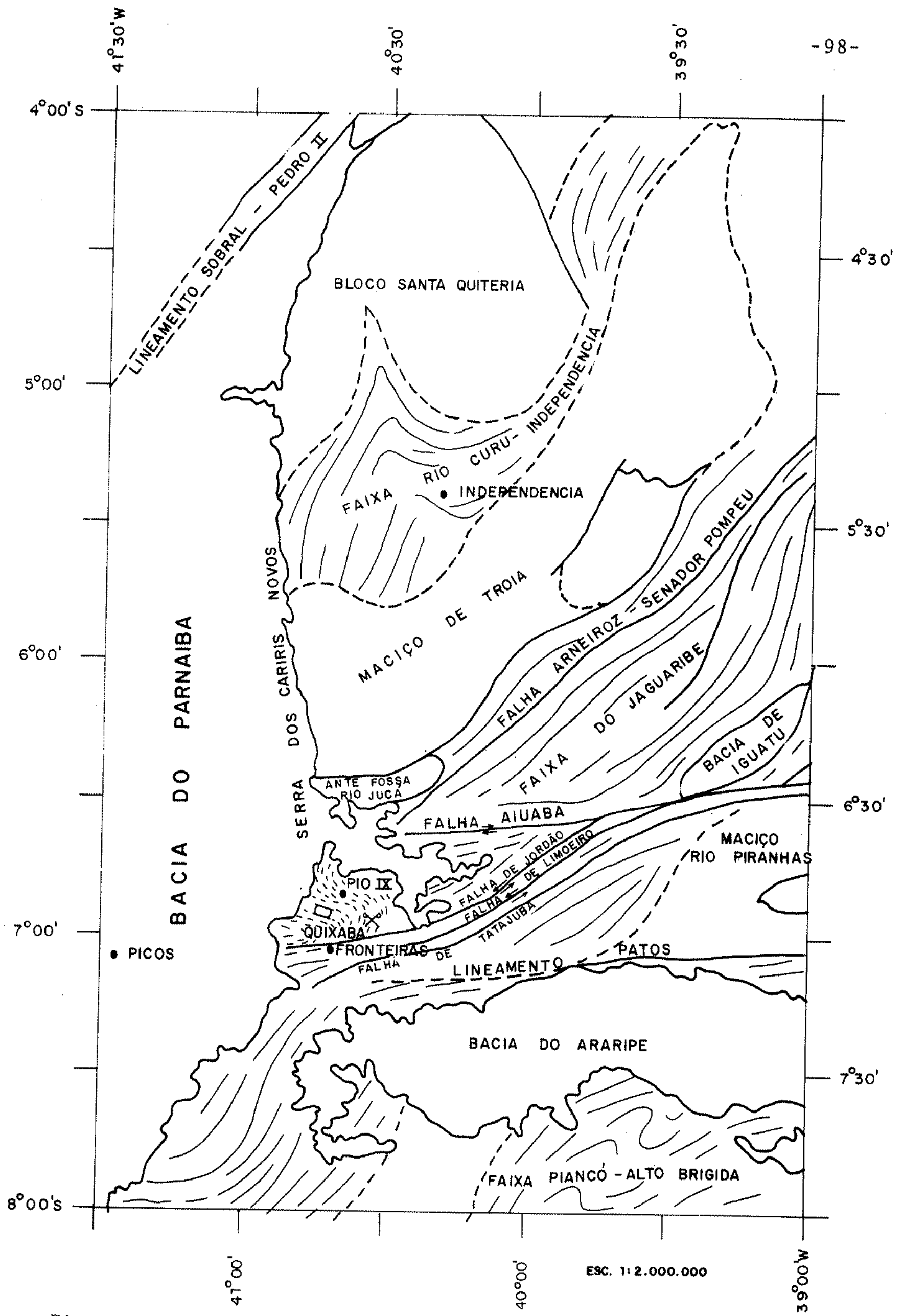

Figura 9 - Sintese geológica e estrutural da região sudeste do Piauí, sudoeste do Cearä e noroeste de Pernambuco (DANTAS, 1974; NEVES. 1975). 
se na teoria regmagênica (MELLO, SOUZA \& MENDONÇA, 1978).

0 cristalino nordestino tem sido muito estudado, tambëm, do ponto de vista hidrogeolögico desde 1913. A FoIha $\mathrm{n}^{8}$ 14, JAGUARIBE-SO(CRUZ \& FRANÇA, 1971), a qual pertence Quixaba, sintetiza todos os levantamentos executados at $\vec{e}$ então. Dentro dos seus objetivos, ela apresenta a constituição litológica da região dividida em rochas do embasamento e rochas sedimentares. As rochas cristalinas apresentam estruturas complexas, com grau de metamorfismo variäve1. A região de Quixaba, mais especificamente, $\vec{e}$ formada por rochas migmatiticas, compreendendo gnaisses bandados, orientados pela distribuição da biotita, quartzo e feldspatos.

Do ponto de vista estratigräfico, atē meados da década de 1960 , as rochas da região eram agrupadas na Sërie Cearä, caracterizada pela sequência de quartzitos, xistos e calcärios, conforme conceituação de Crandall, em 1910 (KEGEL, 1965; SUSZCZYNSKI, 1966). Posteriormente, elas foram reclassificadas como Grupo Seridó (CRUZ \& FRANÇA, 1971).

Em 1973, foi editada a Folha SB-23-TERESINA,

e parte da Folha SB-24-JAGUARIBE, do Projeto RADAM, com base em interpretações de imagens de radar (NUNES, LIMA \& BARROS, 1973). Quixaba esta localizada no Grupo Caraiba, constituído de rochas migmatizadas, conforme conceituação de Barbosa em 1965. O principal termo litolögico desse grupo è um biotita gnaisse cinzento, com intercalações maiores de anfibolitos, quartzitos, micaxistos e enclaves menores de clorita xistos, piroxenitos, serpentinitos, anfibölio asbestos, talco xistos. Ocorrem, igualmente, inümeros corpos graniticos circulares e veios pegmatiticos, interpretados como sendo produtos de intensa migmatização.

Em 1974 foi editada a Folha SB-24 JAGIIARIBE (DANTAS, 1974) com referências pouco claras à geologia e es- 
tratigrafia da região de Quixaba sob pretexto de falta de dados.

Em 1974, tambëm, foi concluído o Projeto

Cococi

(FERREIRA \& BARROS, 1974; OLIVEIRA, FORTES, GOMES \& LINS, 1974) considerado o primeiro trabalho sistemätico na região com finalidades mineralogenëticas.

Por se tratar de um projeto pioneiro, com problemas de falta de datações radiomëtricas, seus autores estabeleceram a estratigrafia da ärea com base nos aspectos estruturais e litológicos das unidades individualizadas nos traba1hos anteriores. Ademais, alegam que a migmatização das rochas e a inexistência de horizontes guias de longo alcance, dificultam o estabelecimento de uma coluna estratigräfica.Por isso simplificam o Precambriano da região do projeto em dois complexos de natureza litológica, Precambriano A e Precambriano $B$, como os pröprios autores salientam, sem nenhum sentido cronolögico.

Assim, o Precambriano A, ao qual pertence Quixaba, constituído de rochas graniticas e migmatítitcas ē representado por faixas sinclinoriais rebaixadas em relação ao Precambriano B, separados por grandes falhamentos inversos ou transcorrentes. A unidade A do Precambriano é caracterizada pela ampla estrutura dobrada em "S" (Foto 1) limitada ao norte pela Falha de Aiuaba, ou recoberta pelos sedimentos paleozóicos da Bacia do Parnaíba, e ao sul pela Falha do Jordão (Figua 9). Na porção sul dessa estrutura as rochas apresentam mergulhos verticais a subverticais nas porções externas dos grandes curvamentos e de $30^{\circ}$ a $75^{\circ}$ nos nücleos dos mesmos. Os materiais centrais texiam reagido incompetentemen te à dinâmica do dobramento enquanto que os das porções exter nas competentemente. Nas porções externas, ainda, os esforços direcionais afetaram o pacote metassedimentar com amplos deslocamentos. Um exemplo dessa perturbação é o estrangula- 
mento do corpo de märmore em Quixaba (Figuras 10 e 11). Em vista da homogeneidade do fraturamento e da constância dos ângulos com os estratos, os autores aventam a posíibilidade de que tais rupturas tenham sido desenvolvidas consequente e concomitantemente com o dobramento.

O Projeto Cococi (FERREIRA \& BARROS, 1974;OLIVEIRA, FORTES, GOMES $\xi$ LINS, 1974) consideram três unidades Iitolögicas no Precambriano.A, integrante do Bloco Orogênico de Banabiū (KEGEL, 1965): l - migmatitos heterogêneos e biotita e/ou hornblenda gnaisses; 2 - biotita xistos e gnaisses xistosos; 3 - filitos.

Conforme o mapa geolögico do Projeto Cococi, Quixaba pertence a primeira unidade, constituida de metassedimentos, com faixas brechadas, cataclasadas ou milonitizadas, e com intercalações de granulitos, rochas carbonáticas, talcoxistos, quartzitos e anfibolitos.

Os biotita e/ou hornblenda gnaisses apresentam estruturas paralelas a plano-paralelas definidas pela disposição dos mäficos dentro da massa quartzo-feldspätica de granulação fina a mẻdia. Em lâmina delgada foi reconhecida uma textura variäve1 entre lepidoblästica a granoblästica,formada por quartzo, ortocläsio, microclinio, plagiocläsio, biotita, hornblenda e alanita, bastante recristalizados e com forte extinção ondulante. Essas rochas são frequentes nos núcleos das curvaturas e interpretadas como resultantes de esforços compressivos.

Os migmatitos ocupam posições mais externas das dobras associados à fraturas de descompressão. São particularmente frequentes próximo à Quixaba, aflorando na passagem da estrada Pio IX-Campos Sales sobre o Riacho do Marçal (Figura 10).

As intercalações de granulitos, rochas carbonáti- 
cas, talco xistos, quartzitos e anfibolitos ocorrem em corpos concordantes. São rochas equigranulares com fortes expressões topogräficas em forma de cristas.

Microscopicamente os anfibolitos são constituídos de hornblenda, plagioclảsio, quartzo, epídoto, sericita, hematita, titanita, leucoxênio, apatita e clorita. Apresentam fraturamento com orientação preferencial, preenchido por quartzo e epidoto, e mostram cristais de anfibölio e plagioclásio fragmentados.

Os granulitos são rochas claras de granulação fina a mëdia, constituídas de quartzo, microclina, hornblenda, diop sidio, hedembergita, aegirina, augita e acessörios, identificados como hornblenda granulito, piroxenito granulito, ou muscovita granulito.

Os talco xistos são esverdeados, sedosos, constituí dos de talco, anfibólio, öxido de ferro e clorita.

As rochas carbonatadas são predominantemente brancas, mas variam ate cinza escuro, com granulação fina e sacaroidal. Quando aflorantes, são facilmente reconhecidas pela carstificação e quando não aflorantes pelo solo avermelhado, argiloso, que contrasta com os solos cinzentos, arenosos, dos outros tipos de rochas. Microscopicamente elas apresentam textura granoblästica, formada por cristais de calcita, opacos, titanita, biotita cloritizada e muscovita.Em Quixaba, no contato com as encaixantes, foi identificado calco-hornfels constituído de diopsídio, epídoto, zoicita e wollastonita.

Dessa forma, para os autores do Projeto Cococi (FERREIRA \& BARROS, 1974; OLIVEIRA, FORTES, GOMES \& LINS, 1974), o conjunto 1itolögico do Precambriano A mostra fäcies metamörficas, distintas umas das outras pelo grau de migmatização. A fäcies de maior grau teria ocorrido por segré- 
gação äcida posterior e/ou simultaneamente à deformação plästica. Apesar da variação do grau de migmatização, a composição mineralógica é uniforme, representada por grupos de minerais do tipo quartzo-biotita-plagioclāsio e granada-biotita -hornblenda-ortocläsio-plagioclásio, ambas pertencentes a fäcies almandina-anfibolito de WINKLER (1977). A fäcies de menor grau $\vec{e}$ representada pelos xistos e filitos das outras unidades litológicas, possivelmente pertencentes à fäcies de xistos verdes.

Os autores do Projeto Cococi aventam, tambem, a hipôtese de que os granulitos representem zonas de desalcalinização, que teria ocorrido com o aumento de fäcies e, apös sua formação, com a volta à fäcies imediatamente inferior. Eles observaram algumas evidências de retro-metamorfismo que teria originado os anfibölio-talco-xistos e o aparecimento de epidoto-zoicita, principalmente nas zonas de maiores esforços.

Depois do Projeto Cococi, outros levantamentos regionais foram executados.

Em 1977 foi executado o Mapa Geológico do Precambriano do Piauí, com base em imagens ERTS-LANDSTA ( CREPANI, MARTINI, VENEZIANI, PAIVA \& MOÇO, 1977). Esse mapa mostra claramente as principais estruturas da região de Quixaba,considerada como Precambriana Indiferenciada, constituía fundamentalmente de rochas granito-gnaissicas com migmatitos e xistos.

Apesar de não cobrir especificamente a ärea Quixaba, o Projeto Jaguaribe (CAMPOS, BRAGA, MELLO, SOUZA, SILVA \& FRANÇA, 1979) complementa, a leste de $40^{\circ} 30^{\prime}$, as informações geológicas do Projeto Radam, que tem aquele meridiano como limite oriental.

Apesar dos autores que estudaram as äreas sedimen- 
tares vizinhas, desde 1946, terem incluido Quixaba em seus mapas, ela aparece simplesmente como embasamento cristalino Precambriano. Por conterem dados lito e cronologicamente muito acima de até onde poderiam interessar ao contexto geo10 gico de Quixaba, esses trabalhos não foram considerados para a execução desta Dissertação.

A partir de 1969 , em vista das boas qualidades reveladas pelas amostras do märmore de Quixaba analisadas, foi inaugurada a fase dos trabalhos de detalhe com o interesse de numerosos grupos empresariais.

o primeiro foi da Bahia, tendo iniciado as atividades de lavra imediatamente apös chegar ao local, mas abandonando-as pouco depois sob a alegação de má qualidade do märmore para cantaria.

o segundo foi um tradicional minerador de märmore do Rio Grande do Norte. Ele tentou preparar novas frentes de desmonte de blocos, mas tambëm desistiu do intento face às dificuldades de acesso à äréa e a grande quantidade de impurezas da rocha.

O terceiro foi a Companhia Cearense de Mineração COCEMI. Suas atividades constaram da legalização da ārea junto ao Departamento Nacional da Produção Minera1-DNPM, a abertura de algumas frentes de desmonte, das quais foi retirada, beneficiada e comercializada em Fortaleza boa quantidade de blocos. Diante das boas perspectivas, esse grupo solicitou financiamento para industrialização em maior escala,junto à Superintendência de Desenvolvimento do Nordeste - SUDENE, importou da Itália dois teares diamantados e executou uma sondagem rotativa de 65 metros para abastecimento de ägua.

Para julgamento tëcnico do financiamento pleiteado, pela COCEMI, geỏlogos do $4^{\circ}$ Distrito do DNPM e da SUDENE 
estiveram em Quixaba em março de 1971. Seu parecer sobre a jazida foi:

- quanto à morfologia e tamanho do depósito "grande lente de calcário cristalino, com espessura aparente de 500 a 1000 metros e quilômetros de extensão";

- quanto à litologia e estruturas "as rochas de contato são gnaisses xistosos, cataclasados por falhas, que afetaram inclusive o mármore com fraturas (fios) e inclusões silicảticas (cravos), inutilizando-o como pedra ornamental junto aos contatos; mais para o centro da lente diminuem as fraturas e inclusões, mas não chegam a desaparecer totalmente, porêm sem invalidar seu uso como matêria prima para märmore";

- quanto à granulação "ê muito boa";

- quanto à cor "o calcảrio cristalino ê predominantemente de cor cinza, ora mais claro, ora mais escuro, com variações para verde e róséo (mārmores fantasia), onde é notöria a presença de inclusões de xisto anfibolítico(cravos), responsäveis pela tonalidade esverdeada, e de pegmatitos de elevada dureza. Apesar de bonito, o tipo menos frequente (menos de $10 \%$ apesar da regular quantidade) è o märmo re branco leitoso, longe de apresentar a homogeneidade do de São Rafael (RN) .

Depois de recomendarem ensaios industriais

em amostras de rocha da porção central do corpo, menos afetado por cravos e fraturas, fundamentados nos insucessos anteriores de grupos tradicionais no ramo, eles emitem seu parecer sobre Quixaba reiterando a opinião anterior de Afrânio V. Carneiro "a maioria absoluta da matêria prima disponível na jazida $\vec{e}$ de aceitação bastante limitada no mercado de märmore o que compromete de certa forma o sucesso do empre- 
endimento na escala projetada" (FRANCO \& FERREIRA, 1971).

Com esse parecer negativo o grupo cearense também se retirou de Quixaba, deixando ainda encaixotados os teares e grande quantidade de blocos extraídos, tendo a Companhia de Mârmore do Piauí - COMAPI assumido o controle da jazida.

Em março de 1973, mediante o Acordo de Assistência Técnica Brasil-Inglaterra e por solicitação da Secretaria de Desenvolvimento do Governo do Estado do Piauí, esteve em Quixaba o engenheiro de minas P.G. Linzel1, do Institut of Geological Sciences, de Londres, para formular recomendações ao bom aproveitamento da jazida. Suas observações foram:

- quanto à morfologia da área "pouco montanhosa, com a maioria dos afloramentos nos altos topográficos, de difícil acesso pela densidade da vegetação";

- quanto à forma e tamanho do jazimento "grandes proporções, com largura média de 500 a 1000 metros, 10 qui1ômetros de extensão na direção N-S, e mais de 60 metros de profundidade, em vista da sondagem rotativa e escavações jä realizadas";

- quanto à 1itologia "as rochas laterais são xistos micäceos e gnaisses com veios de quartzo";

- quanto à qualidade do mảrmore "parece ser uniforme, mas com coloração extremamente variảvel na vertical e na horizontal; a deteorização observada $\vec{e}$ apenas superficial";

- quanto à economicidade "estimativa de custo de produção indicam alta viabilidade, com rentabilidades gradatịvamente maiores à medida que os equipamentos forem amor- 
tizados e a produção for aumentada";

- quanto às recomendações "devem ser construídas vias de acesso, executados levantamentos topográficos e geologicos de detalhe para bom controle da cor, executadas sondagens para cubagem do corpo de märmore e obtenção de āgua para alimentação dos teares, realizadas pesquisas para aproveitamento dos subprodutos, realizadas pesquisas de mercado".

As conclusões de LINZELL (1973) foram altamente favoräveis a um empreendimento mineiro em Quixaba mostrando que a jazida $\vec{e}$ do tipo, que em outras partes do mundo, estão sendo operadas comercialmente para produtos de ornamentação e construção. Elas deram novo alento à COMAPI, então subsidiäria da Companhia de Desenvolvimento do Piauí - ComDEPI que, após legalizar a lavrajunto ao DNPM, procurou obter recursos financeiros junto à SUDENE.

Essa nova solicitação de financiamento motivou a visita do geôlogo H. Beurlen à Quixaba em janeiro de 1975 . Suas observações em afloramentos e frentes de desmonte, atë então existentes, foram:

- quanto ao tamanho da jazida "extensão longitudinal na direção NNE-SSW superior à 6 quilômetros e largura média de 700 metros, havendo $4,2.10^{6} \mathrm{~m}^{3}$ de märmore por metro de profundidade; reservas suficientes para abastecer o projeto da COMAPI";

- quanto à qualidade do märmore "granulação fina, da ordem de $8000 \mathrm{grãos} / \mathrm{cm}^{3}$ (boas caracteristicas granulomëtricas), com coloração variāvel de cinza claro a branco num mesmo afloramento, o que dificulta a obtenção de blocos homo gêneos, com frequentes inclusões de sulfetos, cujo räpido intemperismo ao ser utilizado em revestimentos externos poderä provocar manchas ferruginosas"; 
- quanto ao fraturamento e estruturas do jazimento "em mais de 90\% dos afloramentos, o märmore $\vec{e}$ densamente fraturado ( 2 a 4 fraturas por $\mathrm{m}^{3}$ ), atravessado por leitos (fios) e lentes alongadas (cravos) de quartzo, clorita e anfibōlio, em equidistâncias variảveis de 5 a $50 \mathrm{~cm}$ de um afloramento para outro, inutilizando o märmore como pedra ornamental; apenas numa faixa centra1, com largura variáve1 entre 50 e 200 metros, afastada dos contatos com as encaixantes (xistos, gnaisses e anfibolitos), correspondente à uma zona sinclinal isoclinal complexa (mergulhos dos leitos de $50^{\circ}$ a $90^{\circ}$ ESE e mergulhos dos eixos de $30^{\circ}$ a $50^{\circ}$ ESE) e a uma depressão morfolögica, com carência de afloramentos, a densidade dos fraturamentos, fios e cravos diminui sensive1mente; nas frentes abertas nessa faixa a densidade de fraturas permanece em torno de 2 a 4 por $\mathrm{m}^{3}$, algumas das quais estão preenchidas por carbonato de cālcio de granulação grosseira ( 1 a $2 \mathrm{~mm}$ de diâmetro), restando aberta uma fratura por 2 a $5 \mathrm{~m}^{3}$, aproximadamente; nessas mesmas frentes a frequência de fios e cravos é ainda elevada (equidistâncias de 1 a 2 metros), altamente negativa para a recuperação nas fases de lavra e serragem, possivelmente tornando inviável seu aproveitamento econômico";

- quanto à rentabilidade do empreendimento "a taxa de recuperação nas quatro frentes, comparado o volume total extraído $\left(1850 \mathrm{~m}^{3}\right)$ com o volume de blocos obtidos $\left(450 \mathrm{~m}^{3}\right)$, $\vec{e}$ da ordem de $25 \%$, enquanto que a recuperação normal em minas anâlogas $\vec{e}$ superior a $50 \%$; por isso o volume de insumos para a lavra deverä ser duplicado em relação aos das outras jazidas, alem do aumento adicional relativo ao desgaste dos equipamentos provocado pela frequência de fios e cravos muito mais duros que o märmore".

Concluindo, BEURLEN (1975) analisa os problemas relativos ao abastecimento de ảgua e areia, em seu entender tambëm altamente desfavoräveis ao desenvolvimento do projeto 
da COMAPI em Quixaba.

\section{4 - Trabalhos Recentes em Quixaba}

Diante das controvêrsias da viabilidade de um empreendimento mineiro em Quixaba, principalmente quanto ao fraturamento e às impurezas do märmore, os estudos da jazida foram retomados em 1976. Os trabalhos realizados a partir dessa data visaram definir não só o grau de influência desses condicionantes, no aproveitamento da rocha, como tambẻm o mercado regional de cantaria e a viabilidade de um empreendimento mineiro no local (INSTITUTO DE PESQUISAS TECNOLOGICAS DO ESTADO DE SÃO PAULO S.A., 1975, 1976 C).

No primeiro contato com a ärea, para elaboração do programa de pesquisas, foi notado o intenso fraturamento, de vảrias atitudes, mas que diminuia das bordas para o centro e de alto a baixo dos afloramentos e das frentes das lavras anteriores. Foi notado igualmente o alto grau de impurezas e o aspecto pouco agradâve1 da rocha aflorante, mas que ocorriam variações para materiais mais nobres, principalmente nos locais topograficamente baixos.

Compreendeu-se desde então que fazia-se necessāria a definição da origem, intensidade e atitude de cada fratura mento e do padrão da distribuição das impurezas. Alëm de levantamentos de detalhe das fraturas e variações 1itológicas seria fundamental considerar a evolução geomorfolögica da região.

Assim, como primeira atividade, foi executada a interpretação geológico-estrutural da região (Figura 10), a partir de fotografias aẻreas na escala 1:25.000(INSTITUTO DE PESQUISAS TECNOLOGICAS DO ESTADO DE SÃO PAULO S.A., 1976 A e C) para conhecimento das principais direções estruturais da região e o contorno do corpo de märmore, importante para 


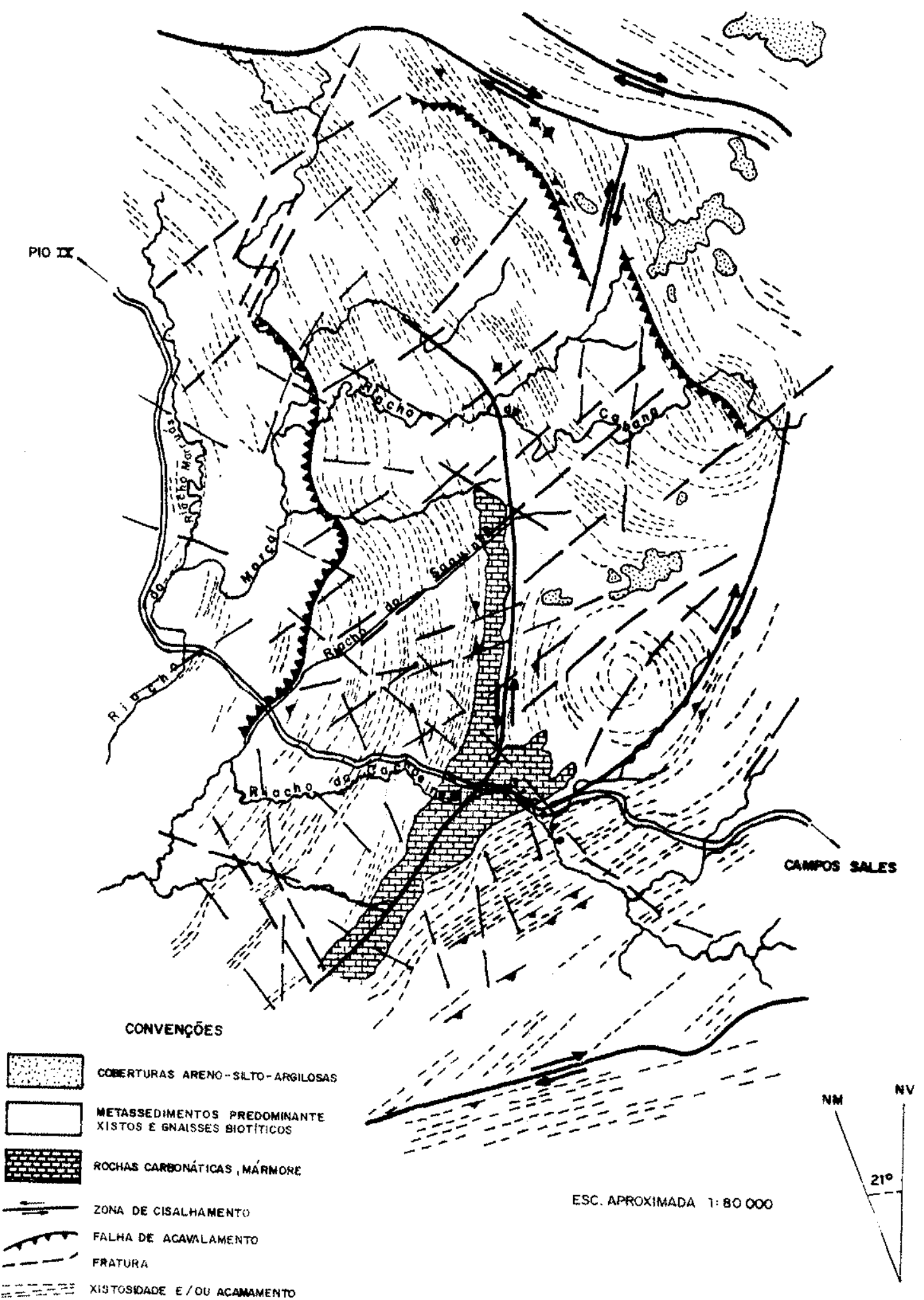

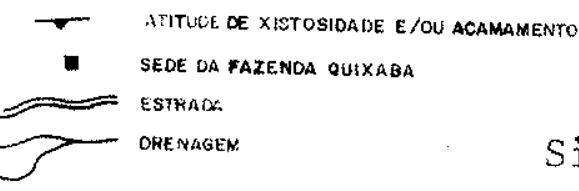

Figura 10

Sintese geológica e estrutural fotointerpretada da região de Quixaba (INSTITUTO DE PESQUISAS TECNOLOGICAS DO ESTADO DE SAO PAULO S.A., 1976A e C). 
orientação na coleta e interpretação dos dados a serem obtidos.

Concomitantemente, para os levantamentos de detalhe, foi implantada uma malha de pontos sobre todo o corpo de rochas carbonáticas, atraves de abertura de duas picadas base ortogonais (OEW e ONS) e algumas picadas secundärias a cada 500 metros. Como o corpo de märmore estā orientado na direção N-S (Figura 10), as linhas base foram planejadas de forma que uma delas the ficasse longitudinal e a outra o dividisse numa porção norte e noutra porção sul (Figura 11).

Todas as 1 inhas foram piquetadas de 10 em $10 \mathrm{me-}$ tros e os pontos foram identificados por um par de inscrições $N$ e $E, N$ e $W, S$ e $E$ ou $S$ e $W$, crescentes para $N, S, E$ e $W$ a partir do ponto de intersecção (ONS-OEW), locado no pätio das oficinas da mina.

Em cada ponto foram tomadas medidas com teodolito para confecção de plantas e secções topogräficas. Como não existia referência de nível oficial pelas redondezas, foi atribuido valor 100 para a cota do ponto origem do sistema de coordenadas (ONS-OEW), a partir do qual os demais pontos têm cotas com valores relativos em metros.

Alêm de elaboração de bases planialtimêtricas,para lançamento, correlação e interpretação dos dados obtidos nos levantamentos de detalhe, a implantação da matha teve a finalidade de orientar, no campo, o levantamento geológico. Ele compreendeu a coleta sistemática, a intervalos medios de 5 metros, de dados sobre a 1itologia e descontinuidades físicas do maciço, tanto nas abundantes exposições de rocha, onde são bem visíveis, como nas porções cobertas por solo. 


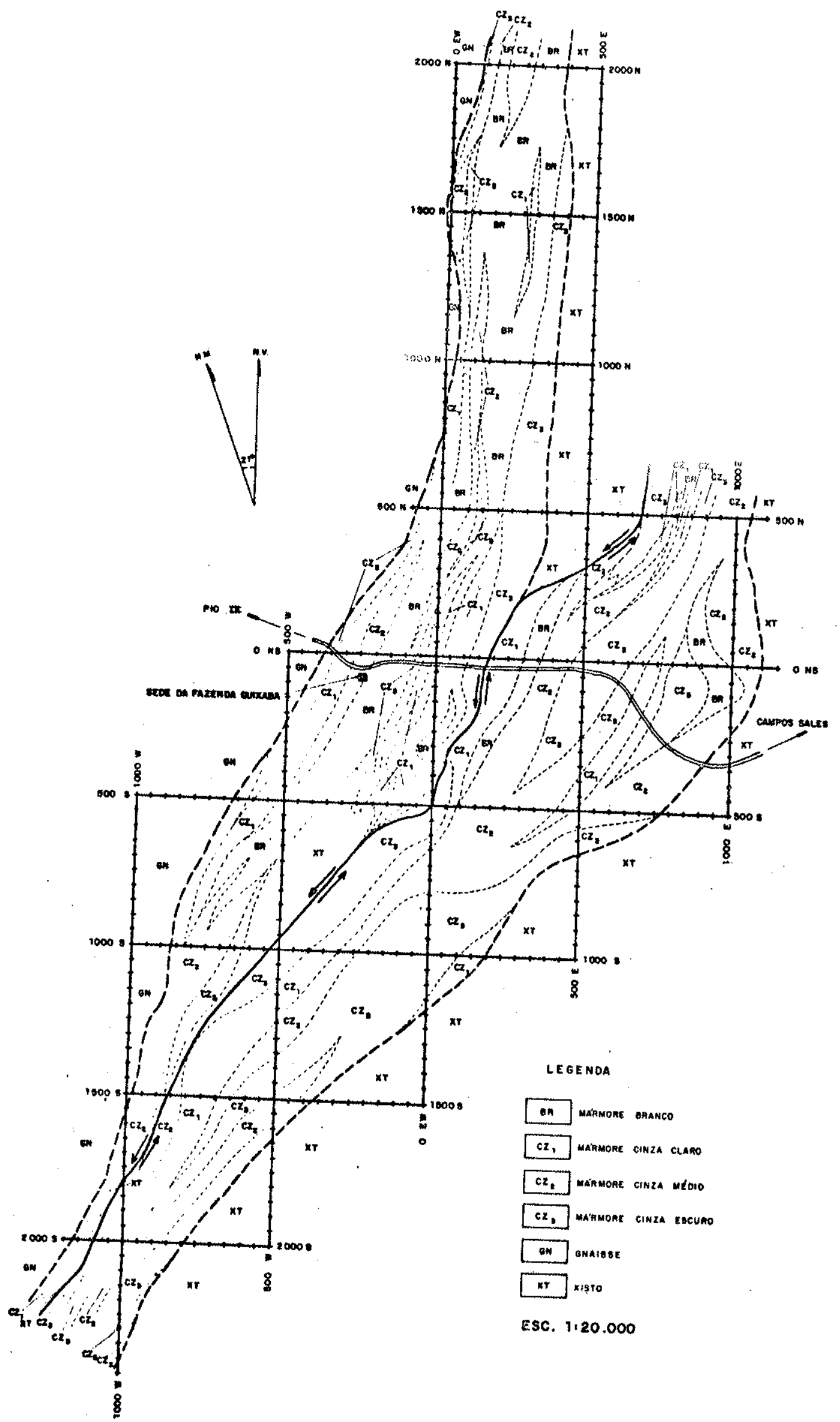

Figura 11 - Mapa geológico de parte do corpo de märmore de Quixaba. 


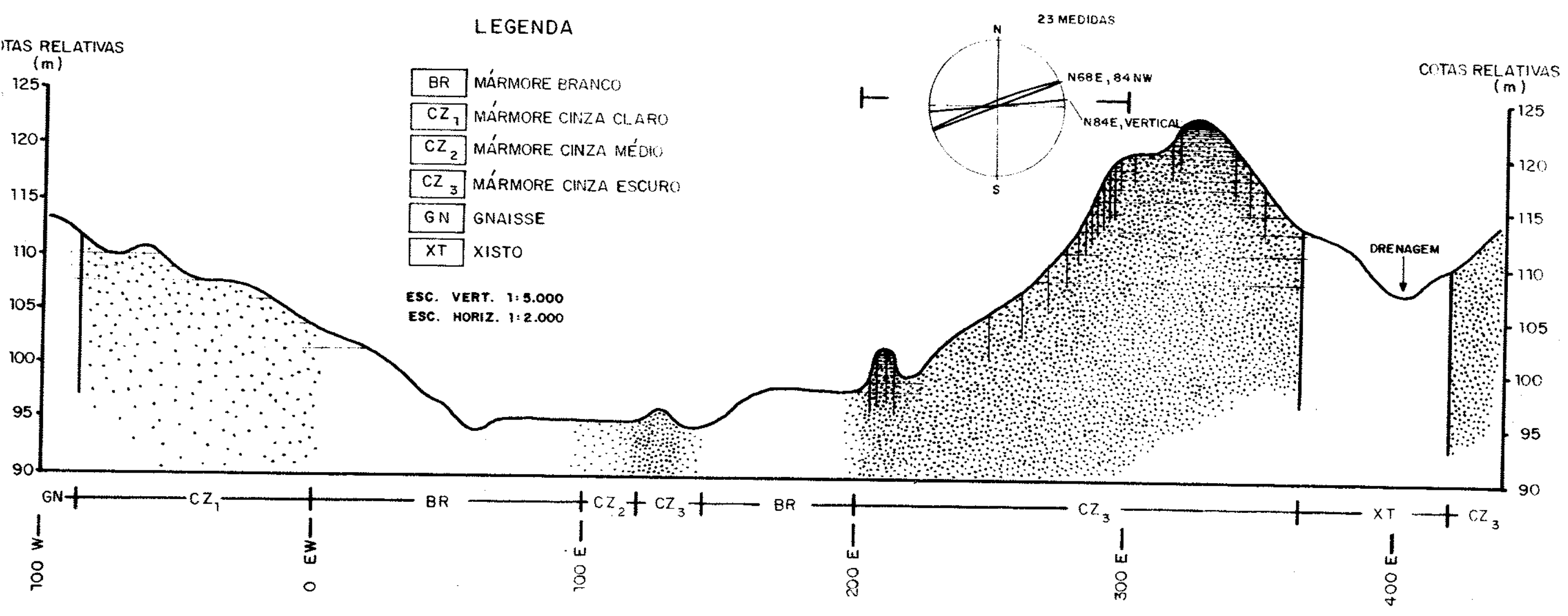

Figura 12 - Seção geológica atravês do corpo de märmore de Quixaba, segundo a linha 500 N. 
campo foi identificar as caracteristicas mineralógicas e tex turais da rocha carbonätica, visando sua classificação como märmore. Foram feitas observações macroscōpicas, tambëm, para delimitação das värias porções do corpo quanto à cor e granulação da rocha (Figura 11). Os estudos de campo foram complementados com observações microscōpicas, no laboratório, segundo as normas $M B-47$ e 48 da ABNT (INSTITUTO DE PESQUISAS TECNOLOGICAS DO ESTADO DE SÃO PAULO S.A., 1976 B), para caracterização mineralógica das rochas (Quadro 17).

As amostras coletadas sobre o corpo de rochas carbonäticas revelaram, em mëdia, $95 \%$ de carbonatos, em cristais geminados de granulação entre 0,5 e 1,5 milimetros, com planos de geminação ligeiramente curvados, indicando cristalização sob tensão (INSTITUTO DE PESQUISAS TECNOLOGICAS DO ESTADO DE SAO PAULO S.A., 1976 A e C). Difratometria por Raios $X$ das amostras revelou predominância da calcita sobre dolomita (Figura 13) e anālise quimica demonstrou conteüdos de $\mathrm{CaCO}_{3}$ em torno de $95,75 \%$ e de $\mathrm{Mg}$ em torno de $0,72 \%$, em peso.

A classificação de märmore cataclástico para as amostras coletadas em 1800S-600W e 1800S-800W (Quadros 17 e 18) foi devida à presença de envoltórias de microcristais ao redor da calcita, segundo faixas orientadas, sugerindo ação de esforços cisalhantes. A amostra foi coletada junto ao contato com xistos, pröximo à zona de cisalhamento que corta o corpo de mármore longitudinalmente (Figuras 10 e 11).

O quartzo tem ampla ocorrência ao lado da calcita, apresentando-se em cristais equigranulares de tamanhos variảveis (milimêtricos e submilimêtricos).

As micas dispõem-se em estruturas planas com comprimento centimétrico e espessura submilimëtrica, às quais se associam quartzo e pirita. Geralmente essas estruturas 

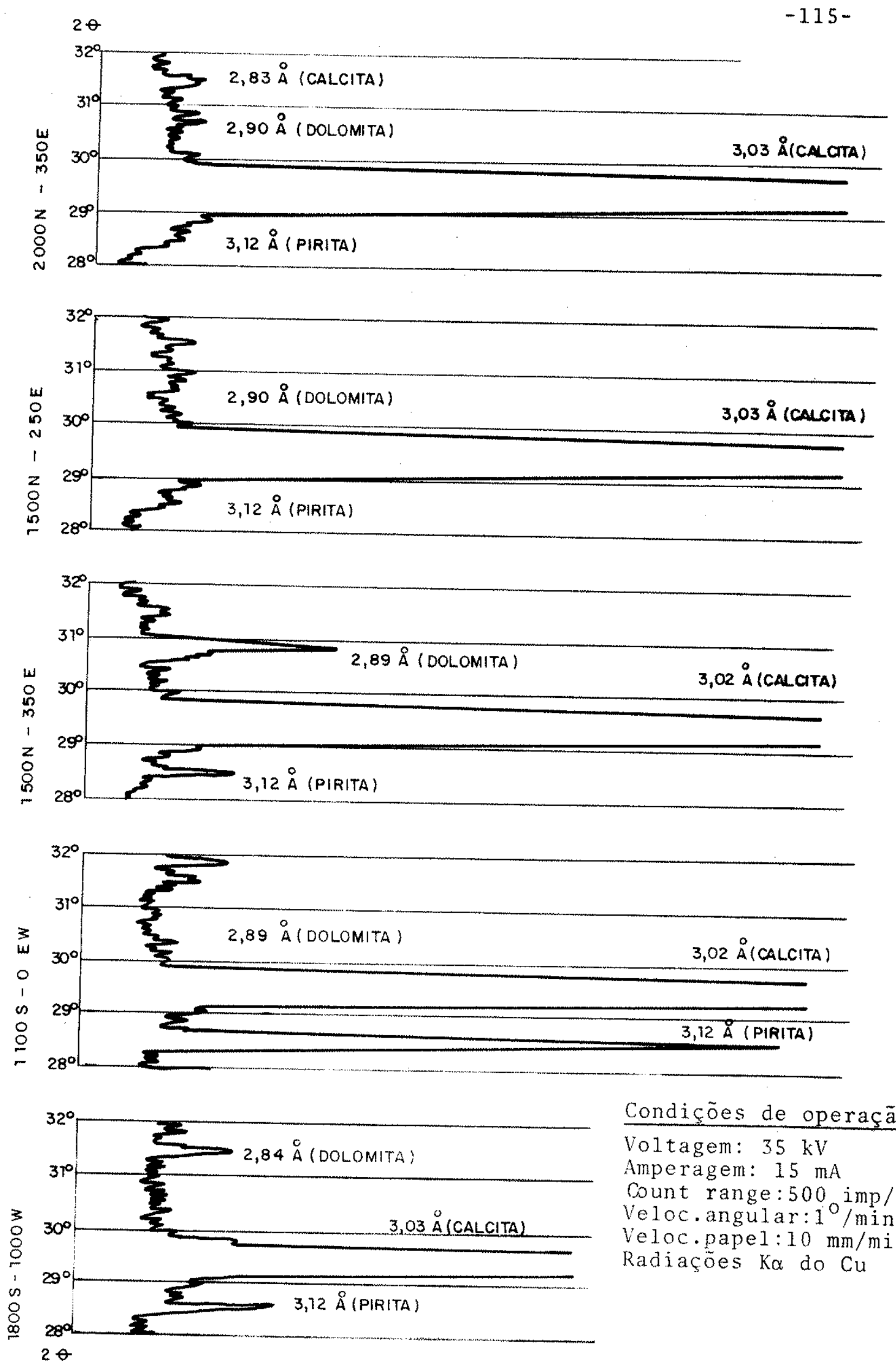

Condições de operação Voltagem: $35 \mathrm{kV}$

Amperagem: $15 \mathrm{~mA}$

Count range: $500 \mathrm{imp} / \mathrm{seg}$

Veloc angular: $1 \%$ min

Veloc.papel: $10 \mathrm{~mm} / \mathrm{min}$ Radiaçöes $\mathrm{K} \alpha$ do $\mathrm{Cu}$

ligura 13 - Difratogramas de raios-X de algumas amostras de märmore de Quixaba. 


\begin{tabular}{|c|c|c|c|c|c|c|}
\hline \multicolumn{7}{|c|}{ QUCroscopis } \\
\hline \multirow{2}{*}{ localixaçâo } & \multirow{2}{*}{ rocha } & \multicolumn{2}{|c|}{ macroscopia } & \multicolumn{3}{|l|}{ microscopia } \\
\hline & & cor & estrutura & minerais & & textura \\
\hline $2000 \times-250 E$ & mármorre & cinca média & compactia & $\begin{array}{l}\text { carbonato } \\
\text { muscovita-clorita } \\
\text { quirtzonfeldspato alcalino } \\
\text { pirita }\end{array}$ & $\mid \begin{array}{l}9(1)-300 \\
10-0 \\
\text { traços } \\
\text { traços } \\
\end{array}$ & gtanoblástica \\
\hline $2000 N-350 E$ & mấrmore & branca & $\begin{array}{l}\text { compacta } \\
\text { bandeada }\end{array}$ & $\begin{array}{l}\text { carbonato } \\
\text { quartzo-felospato } \\
\text { pirita }\end{array}$ & $\begin{array}{l}95+100 \\
5 * 0 \\
\operatorname{sas} 0\end{array}$ & grano-lepidoblástica \\
\hline $2000 N-350 E$ & xisto & preta & $\begin{array}{l}\text { xistosa } \\
\text { injeção } \\
\text { discordante }\end{array}$ & $\begin{array}{l}\text { quartzo-feldspato } \\
\text { biotida } \\
\text { hornblenda } \\
\text { carbonato } \\
\text { apatita-clorira-titanta-epídoto }\end{array}$ & \begin{tabular}{|c|}
50 \\
$30-25$ \\
$10-15$ \\
10 \\
traços \\
\end{tabular} & $\begin{array}{c}\text { grano-lepido-nenato- } \\
\text { biastica }\end{array}$ \\
\hline $\begin{array}{l}1650 \mathrm{~N}-250 \mathrm{E} \\
\text { (2) }\end{array}$ & mármore & branca & compact $\mathrm{a}$ & $\begin{array}{l}\text { carbonato } \\
\text { muscovita } \\
\text { quartzo-feldspato } \\
\text { pirita }\end{array}$ & $\begin{array}{c}25-100 \\
5 \\
5-0 \\
\operatorname{trn} 200 \\
\end{array}$ & gianoblástica \\
\hline $\begin{array}{l}1600 N-250 E \\
(2)\end{array}$ & mármoxe & branco & compacta & $\begin{array}{l}\text { Carbonato } \\
\text { muscovita quartzo-feldspato }\end{array}$ & $\begin{array}{c}95-100 \\
0-5\end{array}$ & granoblästica \\
\hline $1500 \mathrm{~N}-250 \mathrm{E}$ & marrare & branca & $\begin{array}{l}\text { compacta } \\
\text { bandeada }\end{array}$ & $\begin{array}{l}\text { calcita } \\
\text { quartzo-feIdspato alcalino } \\
\text { anfibolio-escapolita-plogioclasio } \\
\text { muscovita-cloritantitanita-apatita } \\
\text { pirita }\end{array}$ & \begin{tabular}{|c|}
$90-100$ \\
$5-0$ \\
$5-0$ \\
tracos \\
2raços \\
\end{tabular} & granoblastica \\
\hline \multirow[t]{2}{*}{$1500 N-350 E$} & \multirow[t]{2}{*}{ märmore } & \multirow[t]{2}{*}{ cinza escura } & brechoide & $\begin{array}{l}\text { Carbonato } \\
\text { quartzo-feldspato alcalino-muscovitampirita }\end{array}$ & $\begin{array}{l}95-100 \\
0-5\end{array}$ & glanoblästica \\
\hline & & & cravos & $\begin{array}{l}\text { quartzo-feldspato-flogopita-muscovita-diop- } \\
\text { sidin-anfibólio-npatita-titanta-pirita }\end{array}$ & & granoblăstica \\
\hline $1000 \times-11 E K$ & gnaisse & cinza rösea & gnaíssica & $\begin{array}{l}\text { quartzo } \\
\text { feIdspato } x \\
\text { muscovitansericita } \\
\text { pirita } \\
\end{array}$ & $\begin{array}{c}40 \\
40 \\
15-20 \\
5-0 \\
\end{array}$ & grano-lepidoblastlca \\
\hline \multirow[t]{2}{*}{$\begin{array}{l}\text { IUnOx }-350 E \\
\text { (2) }\end{array}$} & \multirow[t]{2}{*}{ ขàresore } & \multirow[t]{2}{*}{ cinza escura } & compacta & $\begin{array}{l}\text { carbonato } \\
\text { quartzo-feldspata-muscovita-pirita }\end{array}$ & 100 & granoblästica \\
\hline & & & cravos & $\begin{array}{l}\text { tremolita-diopsídio-quartzo-feldspato-bioti } \\
\text { ta-titanitarpirita }\end{array}$ & 100 & grano-nematoblästica \\
\hline (2) & mármose & cinza clara & compacta & $\begin{array}{l}\text { carbonato } \\
\text { quartzo } \\
\text { muscovita-pirita } \\
\end{array}$ & $\begin{array}{l}95-100 \\
5=0 \\
\operatorname{tracos} \\
\end{array}$ & granoblästica \\
\hline \multirow[t]{2}{*}{$\begin{array}{c}600 N-50 E \\
(2)\end{array}$} & \multirow[t]{2}{*}{ märmore } & $\begin{array}{l}\text { Creme } \\
\text { rôsea } \\
\end{array}$ & compacta & $\begin{array}{l}\text { calcita } \\
\text { quartzo-feldspato-pirita }\end{array}$ & 100 & \\
\hline & & preta & cravos & $\begin{array}{l}\text { quartzo-feldspato-anfibólio-titanita-apat } \\
\text { ta-pirita }\end{array}$ & $x 00$ & grano-nematobiástica \\
\hline $\begin{array}{l}5005-250 \mathrm{E} \\
(2)\end{array}$ & mármore & cinza escura & compacta & $\begin{array}{l}\text { carbonato } \\
\text { muscovita } \\
\text { quartzo-foldspato }\end{array}$ & $\begin{array}{r}95 \\
5=0 \\
5-0 \\
\end{array}$ & granoblästica \\
\hline $50 A x \cdot 500 E$ & xisto & cinza escura & $x$ is tos a & $\begin{array}{l}\text { quartzo-feldspato } \\
\text { biotita } \\
\text { hornblenda } \\
\text { piritia } \\
\text { ipatita-titanita-calcita }\end{array}$ & \begin{tabular}{|c|}
50 \\
$30-25$ \\
$10-15$ \\
10 \\
traços \\
\end{tabular} & grano-lepidoblásetca \\
\hline $\begin{array}{l}100 \times+750 \mathrm{E} \\
(2)\end{array}$ & má rmote & cinza média & bandeada & $\begin{array}{l}\text { carbonato } \\
\text { quarzzo-feldspato } \\
\text { muscovita } \\
\text { pirita } \\
\end{array}$ & $\begin{array}{l}95 \\
5-0 \\
0-5 \\
\text { tracos } \\
\end{array}$ & $\begin{array}{l}\text { granoblästica } \\
\text { cataciästica }\end{array}$ \\
\hline${ }^{(2)}$ (2) $550 \mathrm{E}$ & ตärmore & cinza escura & bandeada & $\begin{array}{l}\text { carbonato } \\
\text { quartzo-feldspato } \\
\text { tremolita } \\
\text { muscovita } \\
\text { pirita } \\
\end{array}$ & \begin{tabular}{|c|}
$80-75$ \\
10 \\
$5-10$ \\
5 \\
tracos \\
\end{tabular} & $\begin{array}{l}\text { granoblästica } \\
\text { cataclastica }\end{array}$ \\
\hline $10005 \times 900 \%$ & xisto & cinza escura & xistosa & $\begin{array}{l}\text { quartzo-feldspato } \\
\text { biotita } \\
\text { carbonato } \\
\text { clorita } \\
\text { pirita } \\
\text { muscovits } \\
\end{array}$ & $\begin{array}{r}65-55 \\
30-35 \\
0-10 \\
5-0 \\
0-5 \\
\end{array}$ & grano-1 epidoblästica \\
\hline T1OOS-OEN & mă rmore & $\begin{array}{l}\text { cinza escura } \\
\text { esverdeada }\end{array}$ & $\begin{array}{l}\text { compacta } \\
\text { bandeada }\end{array}$ & $\begin{array}{l}\text { carbonato } \\
\text { tremolita } \\
\text { quartionfeldspato alcallio } \\
\text { flogopita } \\
\text { titanita-apatita-pirita } \\
\end{array}$ & \begin{tabular}{|c|}
$80-70$ \\
$10-20$ \\
5 \\
5 \\
tracosos \\
\end{tabular} & granoblastica \\
\hline $18005+600 \mathrm{~W}$ & $x i s t 0$ & cinza escura & xistosa & $\begin{array}{l}\text { quartzo-feldspato } \\
\text { biotita } \\
\text { carbonato } \\
\text { horglienda } \\
\text { clorita } \\
\text { pirita } \\
\end{array}$ & $\begin{array}{c}60 \\
30-25 \\
10 \\
0-5 \\
\text { traços } \\
\text { traşos } \\
\end{array}$ & grano-lepidoblästica \\
\hline $\begin{array}{c}1800 \mathrm{~S}-800 \mathrm{~W} \\
(2)\end{array}$ & $\begin{array}{l}\text { mármore } \\
\text { cataciás } \\
\text { tico }\end{array}$ & $\begin{array}{l}\text { Cinza media } \\
\text { esverdeada }\end{array}$ & bandeada & $\begin{array}{l}\text { carbonato } \\
\text { tremolita } \\
\text { quiletzo-feldspato } \\
\text { biotjta } \\
\text { muscovitartitanita-pirlta } \\
\end{array}$ & \begin{tabular}{|c|}
$80-75$ \\
$15-10$ \\
$5-10$ \\
$0-5$ \\
$\operatorname{tracos}$ \\
\end{tabular} & cataclástica \\
\hline $\begin{array}{c}\text { T800S-900W } \\
(2)\end{array}$ & mármore & $\begin{array}{l}\text { Cinza escura } \\
\text { esverdeada }\end{array}$ & bandeada & $\begin{array}{l}\text { carhonato } \\
\text { tremolita } \\
\text { quart } 20-f e b d s p a t o \\
\text { biotita-muscovita-titanita-pirita }\end{array}$ & $\begin{array}{c}80 \times 75 \\
10-15 \\
10 \\
\operatorname{traços} \\
\end{array}$ & granoblastica \\
\hline $1800 S-1000 \mathrm{w}$ & $\begin{array}{l}\text { mármore } \\
\text { catacias- } \\
\text { tico }\end{array}$ & cinza média & gnaíssica & $\begin{array}{l}\text { Carbonato } \\
\text { tremolita } \\
\text { feldspato afenlino } \\
\text { titanitis } \\
\text { clorita-qunrtzo }\end{array}$ & $\begin{array}{c}85-75 \\
10-20 \\
5 \\
0-5 \\
8-505 \\
\end{array}$ & granoblástica \\
\hline $\begin{array}{l}2150 s-1200 W \\
(2)\end{array}$ & márnore & $\begin{array}{l}\text { rosada } \\
\text { esverdeada }\end{array}$ & bandeada & $\begin{array}{l}\text { carbonato } \\
\text { biotita } \\
\text { quartzo } \\
\text { muscovita } \\
\text { clorita-feldspato-titanitapptrita } \\
\end{array}$ & $\begin{array}{c}80-75 \\
15-10 \\
5-10 \\
0-5 \\
\operatorname{trasos} \\
\end{array}$ & 8ranoblástica \\
\hline \multirow[t]{2}{*}{ Bloco } & \multirow{2}{*}{ mároute } & cinza clara & & $\begin{array}{l}\text { carbonato } \\
\text { quartzonfeldspato alcalino } \\
\text { muscovita-sericita-diopsidio-pirita }\end{array}$ & $\begin{array}{c}95-100 \\
0-5 \\
\text { traços }\end{array}$ & gianoblastica \\
\hline & & cravos & & $\begin{array}{l}\text { quartzo-feldspato-anfibolio-diopsídio-tita } \\
\text { nita-apatita-pleita }\end{array}$ & 100 & granoblástica \\
\hline
\end{tabular}

\section{(2) Ver Quadro 17}




\begin{tabular}{|c|c|c|c|c|c|c|c|c|c|c|c|c|}
\hline \multirow{3}{*}{ LOCALIZAÇAO } & \multicolumn{12}{|c|}{ QUADRO 18 - CARACTERISTICAS T } \\
\hline & \multirow{2}{*}{$\begin{array}{c}\text { PESO ESPECIFICO } \\
\text { APARENTE A SECO } \\
{\mathrm{g} / \mathrm{cm}^{3}}^{3}\end{array}$} & \multirow[t]{2}{*}{$\begin{array}{c}\text { PESO ESPECIFICO } \\
\text { APARENTE SATURADO } \\
\mathrm{g} / \mathrm{cm}^{3}\end{array}$} & \multirow[t]{2}{*}{$\begin{array}{c}\text { ABSORÇAO } \\
D^{\prime} \AA G U A \\
:\end{array}$} & \multirow[t]{2}{*}{$\begin{array}{c}\text { POROS IDADE } \\
\text { APARENTE } \\
\&\end{array}$} & \multirow[t]{2}{*}{$\underset{\mathrm{m} \Omega}{\text { DESGASTE }}$} & \multirow[t]{2}{*}{$\begin{array}{l}\text { RESISTENCIA } \\
\text { A FLEXAO } \\
\mathrm{kgf} / \mathrm{cm}^{2}\end{array}$} & \multicolumn{2}{|c|}{$\begin{array}{c}\text { RESISTENCIA A } \\
\text { COMPRLSSTO AXIAL } \\
\text { SINITIES } \\
\mathrm{kgf} / \mathrm{cm}^{2} \\
\end{array}$} & \multicolumn{2}{|c|}{ 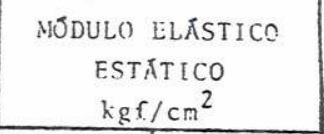 } & \multicolumn{2}{|c|}{$\begin{array}{c}\text { WDLLO ELASTICO } \\
\text { DIXIUICO } \\
\mathrm{hgf} / \mathrm{Cm}^{2} \\
\end{array}$} \\
\hline & & & & & & & SECO & SATURADO & SECO & SATURADO & SECO & SATURADO \\
\hline $1650 \mathrm{~N} / 250 \mathrm{E}$ & 2,72 & 2,73 & 0,11 & 0,32 & 2,66 & 140 & 830 & 800 & 853000 & 564500 & 893000 & $7: 0$ 0ne \\
\hline $1600 \mathrm{~N} / 250 \mathrm{E}$ & 2,71 & 2,72 & 0,23 & 0,62 & 2,90 & 130 & 840 & 860 & 660000 & 626500 & $844 \quad 000$ & 810030 \\
\hline $1000 \times / 350 E$ & 2,74 & 2,74 & 0,04 & 0,12 & 2,21 & 130 & 930 & 900 & 833000 & 827000 & 882000 & 805000 \\
\hline 6OON/OEE & 2,73 & 2,74 & 0,12 & 0,32 & 3,09 & 160 & 1200 & 1100 & 707000 & 607000 & 860000 & $795 \quad 000$ \\
\hline $600 \mathrm{Y} / 50 \mathrm{E}$ & 2,71 & 2,71 & 0,15 & 0,41 & 2,44 & 130 & 800 & 700 & 662000 & $598 \quad 500$ & 840000 & $=10000$ \\
\hline $500 \times / 250 \mathrm{E}$ & 2,73 & 2,73 & 0,18 & 0,50 & 2,78 & 155 & 980 & 970 & $700 \quad 500$ & $554 \quad 500$ & 818000 & -61000 \\
\hline $100 . / 750 \mathrm{E}$ & 2,71 & 2,71 & 0,13 & 0,34 & 2,27 & 140 & 1010 & 900 & 721000 & $578 \quad 000$ & 823000 & 810 ant? \\
\hline $0: 5 / 550 \mathrm{E}$ & 2,72 & 2,72 & 0,09 & 0,24 & 1,72 & 160 & 1250 & 1300 & 803000 & $800 \quad 000$ & 812000 & 7700010 \\
\hline $1800 \mathrm{~s} / 900 \mathrm{w}$ & 2,73 & 2,73 & 0,10 & 0,27 & 1,93 & 170 & 1300 & 1050 & 706000 & 669500 & 781000 & 766000 \\
\hline $18005 / 800 \mathrm{~W}$ & 2,77 & 2,77 & 0,04 & 0,10 & 1,81 & 170 & 1440 & 1180 & 690500 & 644500 & 811000 & 750000 \\
\hline $2150 \mathrm{~S} / 120 \mathrm{ckH}$ & 2,72 & 2,73 & 0,16 & 0,42 & 2,44 & 180 & 1400 & 1020 & 569000 & 521500 & 760000 & 755000 \\
\hline
\end{tabular}

Ver no Quadro 17 as características petrogräficas das amostras.

* instituto de pesquisas tecnologicas do estado de são paulo s.a.,1976 B. 
mostram as micas e as piritas parcial ou totalmente alteradas, tingindo o märmore de ferrugem, e representam planos de maior fraqueza às solicitações mecânicas. Os minerais micảceos são frequentes na porção sul do corpo e são representados por muscovita, flogopita e, mais raramente, clorita.

Dentre os metä1icos, predomina a pirita

(Figura 13). Todos se distribuem segundo zonas bem definidas dentro do corpo de märmore, concentrados nas bandas escuras. Apresentam-se normalmente oxidados, e sua lixiviação deixa pequenos orifícios geométricos, moldes dos cristais idiomórficos removidos.

o anfibólio, que ẻ raro por toda a ảrea estudada, ocorre notadamente no extremo sul do corpo, em ripas submilimëtricas e raros cristais com, no mäximo, 2 milímetros. Em geral é tremolita.

Foram reconhecidos tambëm feldspato alcalino, em cristais inferiores a $0,1 \mathrm{~mm}$, escapolita, sericita, titanita, apatita, dionsídio e plagioclásio.

Os minerais não-carbonāticos ocorrem, ou isolados, em bandas difusas e interdigitadas (Figura 11), ou agrupados, em nỏdulos (Foto 5). Em qualquer caso essas formações são concordantes com a atitude geral do corpo facilmente descartảveis no momento da extração.

Nas bandas difusas e interdigitadas, os não-carbonatos, não formam associações paragenëticas no conceito de WINKLER (1977), motivo pelo qual foram interpretadas como resultantes de material estranho (areias e argilas) depositado intercaladamente no pacote carbonático, refletindo o acamamento.

As concentrações nodulares foram interpretadas co- 


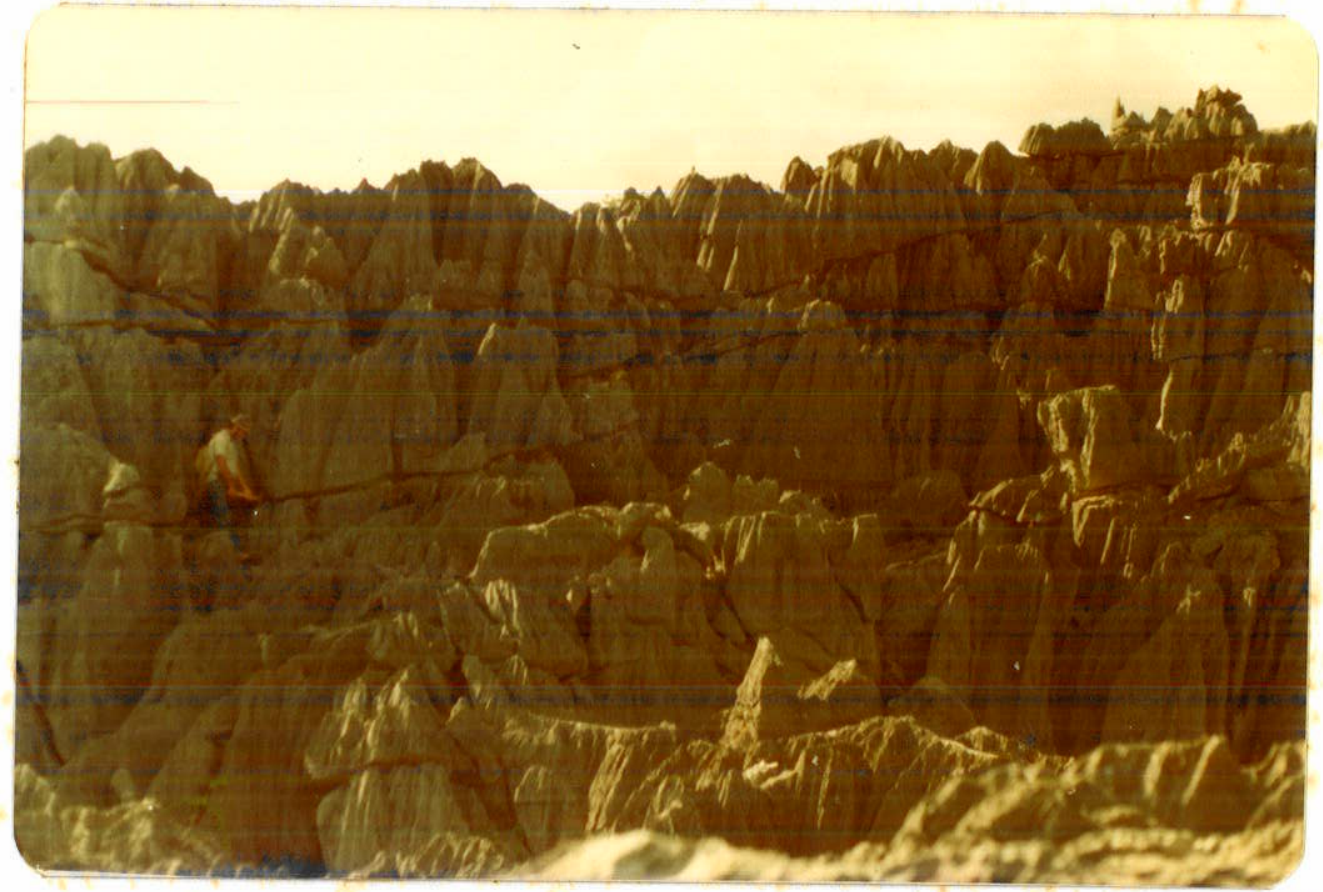

Foto 4 - Vista da escarpa de uma das elevações mostrando o fraturamento horizontal e as caneluras

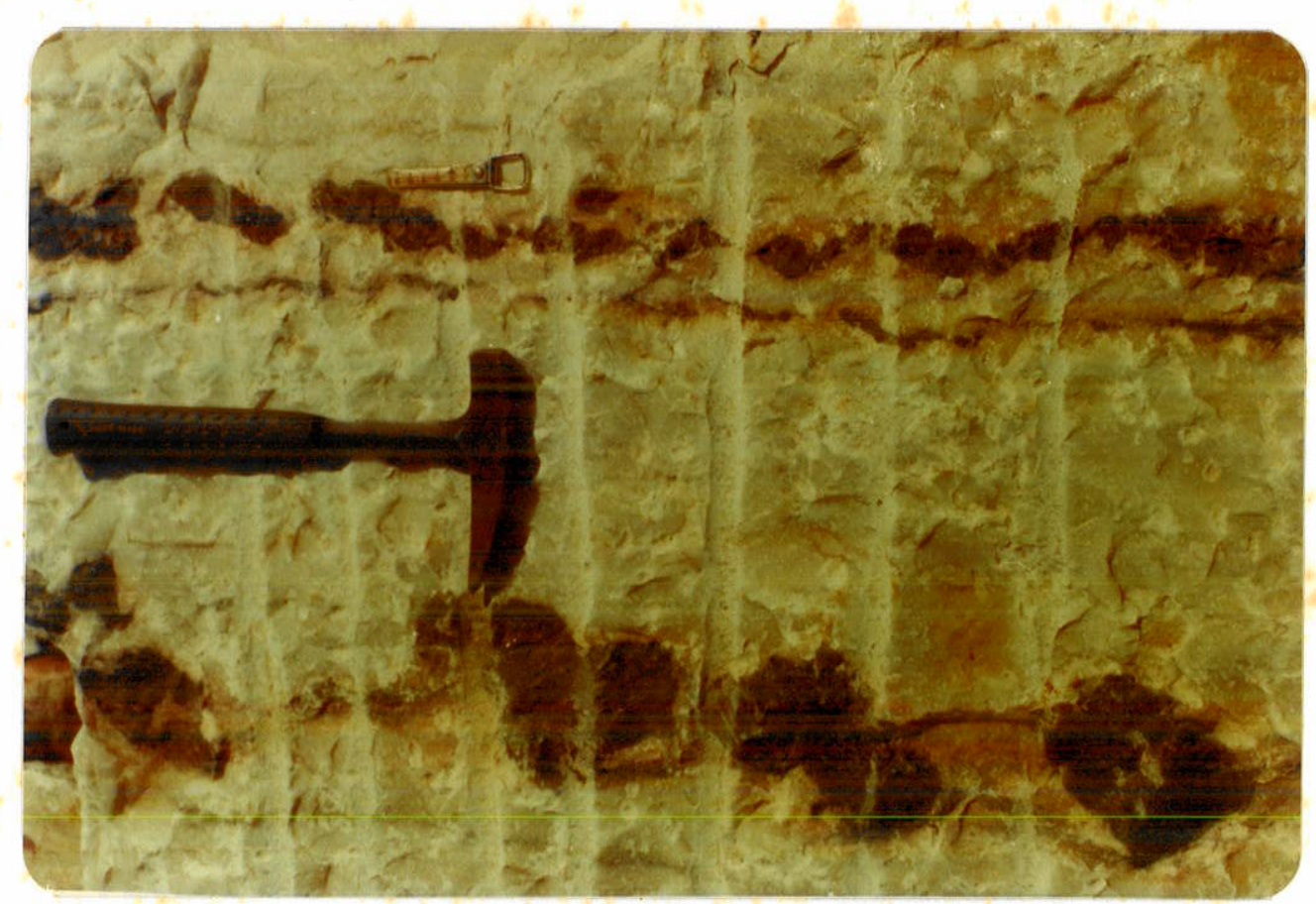

Foto 5 - Horizontes de nódulos silicáticos intercalados concordantemente no corpo de märmore de Quixaba. 
mo camadas argilosas que, reagindo competentemente aos esforços cisalhantes, formaram "boudinage" (Foto 5) no conceito de BILLINGS (1964) e BELOUSSOV (1971).

Nas extrações em geral, os nỏdulos (Foto 2) são designados como "cravos", uma terminologia pouco técnica,mas adotada por faltar outra melhor e por estar profundamente enraizada entre os trabalhadores das pedreiras de cantaria.Ela designa tão somente as concentrações nodulares de minerais não-carbonâticos, independente de sua origem ou natureza. Os cravos são importantes para a conceituação da jazida por representarem núcleos de resistência da rocha ao desmonte, ao corte e ao polimento.

Os minerais não-carbonäticos ocorrem, tambẻm, em formações discordantes, com nîtidas evidências de injeções as quais se associam concentrações de metālicos. São de natureza pegmatítica ou bảsica e penetram tanto os xistos quanto o mármore, ocorrendo principalmente na borda leste da porção norte do corpo de mármore. Nesses locais são freqúentes veios de quartzo leitoso, ao redor dos quais o mármore torna-se silicático, rico em quartzo, feldspato alcalino e mica.

As impurezas do mảrmore, que foram causa de inümeras paralizações de lavras anteriores em Quixaba, revelaram-se controladas por padrões de distribuição restritos, facilmente reconhecíveis, de forma que as porções afetadas possam ser descartadas à medida que a frente de desmonte avançar.

A composição mineral da rocha controla a evolução geomorfológica da área. Enquanto que as porções com rochas mais silicâticas resistiram aos agentes intempéricos, originando as elevações que expõem a rocha da pior qualidade e aspecto (Fotos 2, 3 e 4), as porções de rocha mais carbonāticas originaram os baixos topogräficos, cobertos por solo 
argiloso vermelho (Foto 3). A forma alongada (lenticular), com flancos abruptos, e a disposição (alinhados na direção $\mathrm{N}-\mathrm{S})$ dos afloramentos refletem a sedimentação diferencial de materiais mais e menos carbonaticos.

0 aspecto litolögico do corpo de märmore de Quixa ba mais importante do ponto de vista econômico é a cor. E1a varia ampla e gradativamente em função da composição mineral formando bandas difusas e interdigitadas que, como dito anteriormente, refletem o acamamento pretérito (Figura 11). Nas porções onde predomina calcita a rocha $\vec{e}$ branca, com granulação grossa (sacaroidal) ou fina (leitoso). A medida que aumenta a concentração (até 20\%) dos minerais não-carbonáticos a coloração varia conforme o mineral presente. Foi notada a correspondência da coloração cinza para quartzo, castanha para feldspato e verde para clorita e tremolita.

Em Quixaba a cor varia tambëm de norte para sul do corpo refletindo um controle geotectônico. Enquanto que na porção do corpo ao norte a linha oNS predomina mármore branco, puro, na porção ao sul predominam rochas silicáticas, escuras, com abundância de quartzo e micas. Alēm de diferenças na composição mineral dos sedimentos pretëritos, tal variação foi interpretada como resultante da ação de metamorfismo termal, evidenciado pelas intrusões pegmatiticas e bäsicas, aflorantes na porção norte, e pela estrutura circular (Figura 10). Outros corpos carbonäticos distantes, mas pertencentes ao mesmo pacote dobrado em "S" (Foto 1) não mostram evidências de recristalização como a parte norte do de Quixaba.

Como os trabalhos recentes em Quixaba visaram o corpo de märmore, suas encaixantes foram pouco estudadas (INSTITUTO DE PESQUTSAS TECNOLOGICAS DO ESTADO DE SAO PAULO, 1976 A e C). 
Os xistos ocorrem a leste e ao sul da área concordantemente com o märmore. Eles são representados, principalmente, por hornblenda-feldspato-quartzo-biotita xistos de textura grano-lepidoblästica (Quadro 17). 0 feldspato predominante $\vec{e}$ o plagioclāsio, parcialmente sericitizado, mas também ocorre microclínio subordinadamente. 0 quartzo exibe forte cxtinção ondulante, sugerindo a ação de esforços tectônicos.

o gnaisse ocorre a oeste da ärea passando, gradativamente, para xisto ao sul, com aumento dos minerais placóides. Sua orientação nem sempre é nîtida devido às grandes quantidades de quartzo e feldspato em relação à mica. 0 feldspato predominante é microclínio de coloração rósea.Apre senta-se em blastos de até $2 \mathrm{~mm}$, com intercrescimentos pertíticos, fraturados, e envolvidos por cristais menores de feldspato, quartzo e muscovita-sericita. São frequentes veios de quartzo leitoso cortando os gnaisses.

A preocupação, no reconhecimento estrutural, foi a qualificação e quantificação das descontinuidades físicas do corpo de märmore. Como descontinuidades físicas foram considerados o acamamento e/ou xistosidade e o fraturamento. Seu levantamento constou de contagem por metro linear e da medida de suas atitudes, bem visíveis nos abundantes af10ramentos da ärea (INSTITUTO DE PESQUISAS TECNOLOGICAS DO ESTADO DE SAO PAULO S.A., 1976 A e C).

O exame espacial das fraturas permitiu a identificação de quatro sistemas de fraturamento.

Dois deles têm direções mëdias N84W ou N30-65E e são verticais, ou com fortes mergulhos para SE ou NW. São pouco expressivos em termos de frequência, não comprometendo o aproveitamento da rocha, interpretados como de origem tectônica segundo a fotointerpretação regional (Figura 
10). Os valores das medidas realizadas foram lançados em perfis topográficos (Figura 12) e em diagramas de frequência tipo Schmidt-Lambert. Os resultados foram computados separadamente para as porções norte e sul do corpo de Quixaba (Figura 14).

Outros dois são de origem intempërica, ligados à evolução geomorfolögica da ärea, em geral realçados por dissolução. Foram assim, interpretados por acompanharem nitidamente a superficie (Foto 4) e diminuirem em profundidade.

Um deles tambëm $\vec{e}$ vertical, com direção aproximada N-S, acompanhando o acamamento, originado por alívio de carga lateral (Figura 12). Ele diminui das bordas para o centro dos afloramentos, explicando os flancos abruptos das elevações, e de alto a baixo das mesmas (Foto 3 ).

0 outro é horizontal, ou com mergulhos nunca superiores à $15^{\circ}-20^{\circ}$, paralelo à linha de topo, originado por alivio de carga sobrejacente. Ele tambëm diminui de alto a baixo das elevações, desaparecendo em profundidade (Foto 3 ).

Paralelamente às investigações geolögicas, para anảlise da viabilidade econômica, os estudos recentes em Quixaba, compreenderam uma pesquisa de mercado na sua região de influência (PIAUT, 1976). Como zona de influência foram considerados os Estados do Cearä, Piauí, Maranhão, Parä, e Amazonas. Os demais Estados do Nordeste foram excluidos dada a existência de lavras de märmore para cantaria em atividade no Estado do Rio Grande do Norte e na Bahia.

A pesquisa de mercado constou, em sintese, do $1 \mathrm{e}$ vantamento do volume de venda (consumo) e procedência dos materiais comercializados, atraves de questionários aplicados aos vendedores de cantaria nas principais cidades da região de influência. 

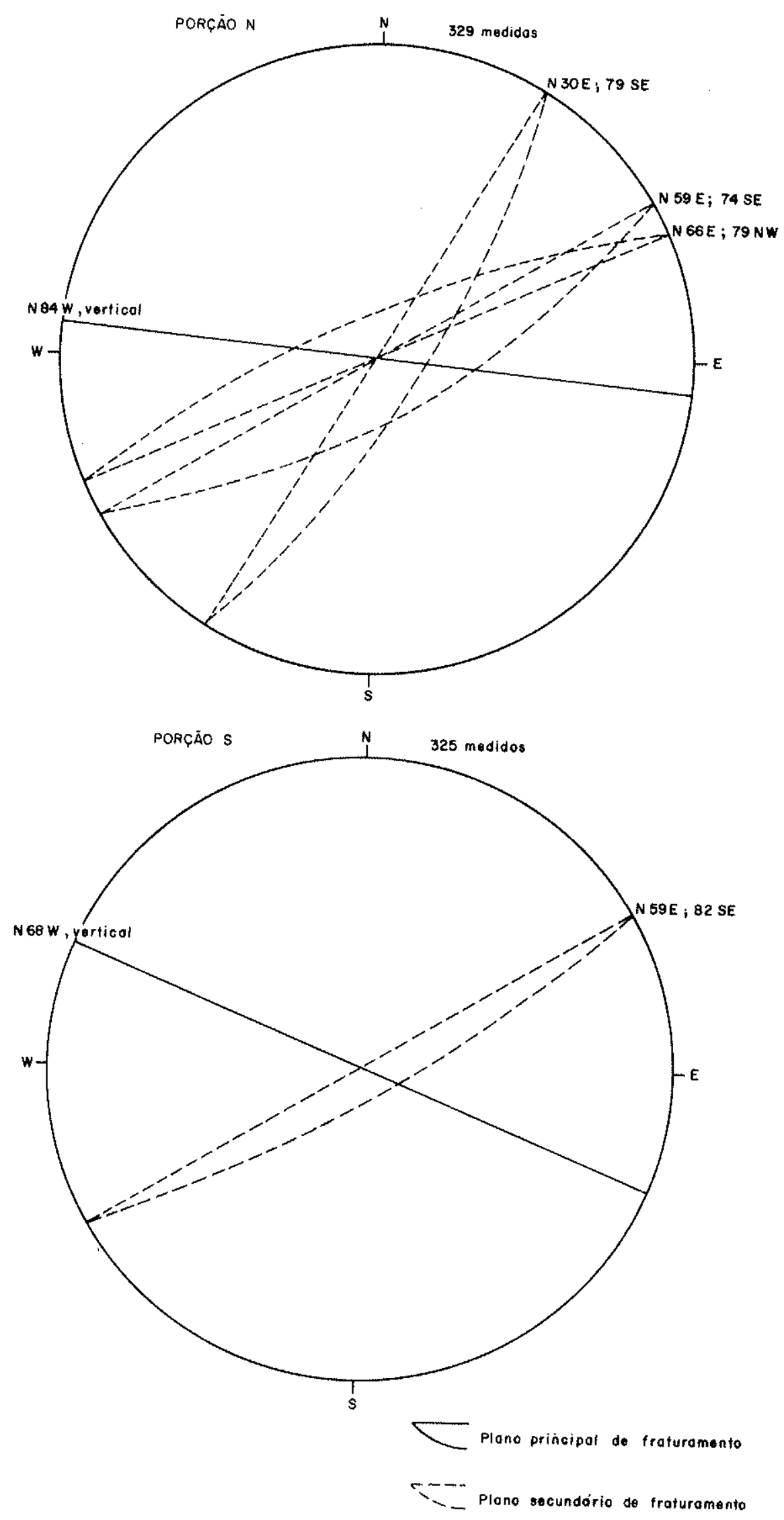

Figura 14 - Diagramas de frequência das fraturas para as porções norte e sul do corpo de mármore de Quixaba. 
Com relação ao volume consumido foi constatado que a utilização de cantarias na região não e muito difundida. Não existem vendedores exclusivos ou especializados na orientação de sua utilização que tem ficado restrita à edifícios públicos, contribuindo para a imagem de material de alto requinte. Tambêm nem todos consumidores têm noção exata da relação do preço do mármore para o de séus substitutos, utilizam madeira de lei ou vitrificados por suporem que sejam de preços mais baixos. Quanto utilizam, ē notävel a preferência do püblico (70\%) pelos märmores de cor branca e uniforme.

Com relação a procedência dos materiais, a pesquisa mostrou que $14 \%$ dos $120.250 \mathrm{~m}^{2}$ consumidos na região em 1975 , provieram das minas do Rio Grande do Norte. Os $86 \%$ restantes foram comprados do Rio de Janeiro (37\%), Espïrito Santo (33\%), Itália (10\%), Minas Gerais (2\%), Paraná e São Paulo $(2 \%)$. O frete foi considerado como principal encarecedor do produto contribuindo com parcelas de $25 \%$ e $50:$ do valor total do produto na região.

A estimativa da demanda futura foi estabelecida em função da quantidade de mârmore consumido na região de influência. Dados sobre esse parâmetro foram obtidos somente para 1973, 1974 e 1975, quando os respectivos consumos foram de $74.000 \mathrm{~m}^{2}, 106.800 \mathrm{~m}^{3}(+44,32 \%)$ e $120.250 \mathrm{~m}^{2}(+12,59 \%)$. A média anual de crescimento é da ordem de $30 \%$, confirmada por $30 \%$ dos 26 revendedores de cantaria da região terem menos de dois anos de funcionamento (PIAU1, 1976).

A pesquisa de mercado salientou as dificuldades na coleta de dados por falta de uma uniformização da terminologia. O maior problema encontrado foi devido à ambiguidade do termo "bloco". Para alguns $\vec{e}$ a peça de rocha retirada da pedreira e para outros é cada placa serrada. A mesma ambiguidade tem trazido dificuldades para os örgãos de con- 
trole do comércio exterior (comunicação verbal de Emanuel Mateus de Castro, Editor da Revista "Rochas de Qualidade").

A partir dos resultados do levantamento litológico-estrutural da jazida e da pesquisa de mercado, foram selecionadas as porções do corpo de märmore mais apropriadas quanto à cor, para caracterização tecnológica e cubagem da rocha.

Em função da cor branca, preferida pelo püblico da região, os estudos recentes em Quixaba se restringiram à porção norte do corpo, delimitada pelas linhas OEW, 400 E, $500 \mathrm{~N}$ e $2000 \mathrm{~N}$ (Figura 11). Consistiram primeiramente de amostragem para ensaios que foram executados segundo recomendaçõcs do"^ Technical Guide to the Rational use of Marble (ITALIAN MARBLE INDUSTRIE, 1972), da Internacional Society for Rock Mechanics, da American Society of Technical Materials ( $A S T M)$, da Associação Brasileira de Normas Técnicas (ABNT) e do Instituto de Pesquisas Tecnológicas do Estado de São Paulo S.A. (IPT). Os índices físicos (peso específico aparente a seco e saturado, absorção de āgua, porosidade aparente) foram executados segundo a Norma IPT-M-47. A resistência ao desgaste abrasivo foi efetuado segundo a Nor ma PMB-849, da ABNT. A resistência à flexão foi determiná da conforme a Norma ASTM-C-78-64 e a compressão axial simples segundo o método IPT-M-50. Os mỏdulos de deformabilidade estảtico e dinâmico foram efetuados segundo métodos pröprios do IPT (INSTITUTO DE PESQUISAS TECNOLOGiCAS DO ESTADO DF SAOO PAULO S.A., 1976-B). OS resultados permitiram concluir que o märmore de Quixaba se enquadra perfeitamente dentro das especificações para cantaria (INSTITUTO DE PESQUISAS TECNOLOGGICAS DO ESTADO DE SÃO PAULO S.A., 1976 B e C, CARUSO, TAIOLI \& FARJALLAT, 1978).

Do ponto de vista estëtico o märmore de Quixaba, se destaca pelo lustro, que adquire com o polimento. E pa- 
ra quem não desejar só a cor branca uniforme, hả rochas capazes de proporcionar belos cfeitos decorativos, pelo seu bandeamento difuso, com tonalidades suaves de cinza, rosa c verde.

Ensaios de alteração acelerada, para avaliar a influência dos metảlicos, não mostraram efeitos depreciativos em curtos espaços de tempo. Mas como é de se esperar que eles se oxidem nas atmosferas poluîdas dos centros industrializados, é recomendävel que as peças que os contiverem sejam utilizadas em revestimentos de interiores (INSTITUTO DE PESQUISAS TECNOLOGICAS DO ESTADO DE SÃO PAULO S.A., 1976 $B$ e C).

Definida a qualidade da rocha, foram desenvolvidas atividades para quantificação de uma quantidade mínima de märmore capaz de viabilizar um empreendimento. Com base nos prazos de 20 anos para amortização de capital e depreciação de equipamentos a taxa de crescimento anual do consumo de $30 \%$, 86\% do qual caberia à Quixaba (PIAUI, 1976) e nas taxas de recuperação dos processos de produção das cantarias de $70 \%$ do maciço para os blocos (MENDES, 1974, 1979 A) essa quantidade mínima é da ordem $1.600 .000 \mathrm{~m}^{3}$.

Partindo-se dos $120.250 \mathrm{~m}^{2}$ consumidos em 1975, em 20 anos terão sido demandados $17.579 .582 \mathrm{~m}^{2}$ de placas de mármore, dos quais $15.118 .800 \mathrm{~m}^{2}$ terão provindo de Quixaba. Para tal produção, tomando-se a média de $23 \mathrm{~m}^{2}$ de blocos para cada $\mathrm{m}^{3}$ de bloco, o volume de rocha em blocos, deverá ser de $1.095 .565 \mathrm{~m}^{3}$ e de rocha no maciço, de $1.565 .094 \mathrm{~m}^{3}$. A partir dos $160.000 \mathrm{~m}^{2}$ em que aflora märmore branco, ou de tonalidades claras, e da atitude vertical do corpo, essa quantidade de material era esperada atê 10 metros de profundidade, descontados o solo e trecho da rocha semi-intemperizada. 
executadas 16 sondagens rotativas, com profundidades médias de $35,5 \mathrm{~m}$, espaçadas de $100 \times 100$ metros. As sondagens foram realizadas com vistas, exclusivamente, à cubagem da quantidade minima para um empreendimento de märmore para cantaria, tendo confirmado as expectativas da uniformidade $1 \mathbf{i}$ tolögica e de inexpressividade de fraturamento do corpo em profundidade.

Para a verificação do fraturamento, foram utilizalos barriletes duplos móveis, de grande diâmetro (NX-BX) e foi imprimida a menor rotação possivel ao hasteamento. Sempre que os segmentos dos testemunhos se encaixavam perfeitamente, as rupturas foram interpretadas como provocadas e não foram computadas para a quantificação de grau de fraturamento. Como alguns dos segmentos giraram uns contra os outros dentro do barrilete, enquanto perdurava a manobra, por vezes não foi possível aplicar esse critério, pelas bases dos segmentos contíguos estarem desgastadas. 0 nümero de fraturas provocadas aumenta com a profundidade, $\bar{a}$ medida que o peso do hasteamento exigia maiores rotações da sonda. Como a maior parte desses casos ocorreram abaixo dos 15 metros necessärios para a cubagem do volume mínimo de rochas, o fato não causou maior preocupação.

Apesar de ter sido cubado somente o mínimo, o potencial em rochas carbonäticas de Quixaba para cantaria e outras finalidades é muito maior em vista das extensões do corpo para norte, sul c leste que não foram estudadas.

Separadas as porções de rocha adequadas para cantaria, a jazida deverá ser aproveitada para outros fins, como cimento, cal, quimica em vista de seus altos teores em $\mathrm{CaCO}_{3}$. Mesmo os sub-produtos da industrialização de cantaria deverão ser aproveitados. 


\section{CONCLUSOES}

Embora os recursos cm pedra para construção civil sejam ilimitâveis em termos globais, sua abundância difere de uma região para outra conforme a natureza geolögica do terreno. Devido ao grande nümero de rochas, de diferentes naturezas e värias propriedades, para diversas apilicações na construção, nenhuma região pode ser considerada autosufi ciente em todas suas necessidades.

De todas as aplicações das rochas em construções, sua utilização mais nobre ê como cantaria, para o que são mais raras e de prospeç̧ão mais difícil. Alëm da rigidez e durabilidade exigidas para utilização na construção para cantaria as rochas devem apresentar suscetibilidade ao poli mento e beleza, só desenvolvidas em condiçōes geolögicas especiais. No entanto em todas as regiões, a prospecção de re cursos desse tipo de rocha tem se caracterizado como a mais cmpírica das atividades da industria extrativa mineral.

A disponibilidade de materiais rochosos para cantaria tem sido agravada com a expansão dos centros urbanos, ell termos de ocupação espacial, demanda e preço dos combustíveis, exigindo a procura de novas fontes, ou a retomada de outras abandonadas, atravês de investigações mais apuradas dos condicionantes geolögicos de sua ocorrência e de scu aproveitamento.

Como para os demais recursos minerais, a prospeccão de reservas em rochas para cantaria consta de qualifica ção e quantificação de jazimento c viabilização do empreendimento. Enquanto que a qualidade é avaliada em termos de posição mineral e textura1, a quantidade $\vec{e}$ avaliada em termos de volume de material disponivel. Nmbas dependem da na- 
tureza geológica do jazimento, que condiciona o aproveitamento da rocha em função do grau de fraturamento, homogeneidade composicional, cobertura regolítica e nível freático. A cconomicidade é regida pelas condições de infraestrutura bâsica para produção e escoamento e de mercado da região de influência.

$\Lambda$ s atividades em Quixaba, contribuiram com grande quantidade de dados para a prospecção de jazidas de märmore para cantaria. Por serem utilizadas na forma maciça, apenas modeladas segundo a forma e dimensões dos projetos arquitetônicos, seus métodos de prospecção devem ser os menos destrutíveis possíve1, fazendo da evolução geomorfológica da região a chave para a interpretação das feições do jazimento c sua maneira de aproveitamento. Nesse sentido são valiosas as observações de superfície atravês de recursos indiretos de sensores (fotografias aẻreas, imagens de radar e satélite) e diretas (mapeamento 1itolögico e estrutural).

Em Quixaba, o corpo de rochas carbonảticas forma uma depressão em relação às rochas silicáticas adjacentes, resultante da ação de intemperismo físico, típico das regiões de clima seco, onde a modelagem de relevo é desenvolvida em função das diferenças litológicas. Nele, as porções com silicatos também resistiram à erosão, originando elevações desnudas que contrastam com baixos de rocha carbonática mais pura, recobertos por solo.

Esse tipo de evolução geomorfológica determina a lavra em cava, como é o caso das jazidas do Rio Grande do Norte e Bahia, diversa da lavra em flanco, como no Espírito Santo, Paraná, Minas Gerais e outros estados do Sul. A economicidade da lavra em cava deve ser avaliada em termos de profundidade até onde é viảvel o alçamento dos blocos e não aflore o nível hidrostätico. A partir de então devem ser feitos estudos para a viabilidade da extração subterrânea co 
mo jả existe em alguns países.

A evolução geomorfolỏgica tambẻm condiciona o comportamento do fraturamento conforme sua origem. Quando de origem intempérica, é apenas superficial e desaparece com a profundidade. Quando de origem tectônica manifesta-se em profundidade. Em qualquer caso é necessärio qualificā-1o e quantificá-1o, considerando que, mesmo para cantaria e alvenaria, é conveniente que o maciço apresente direções de fraqueza para facilidade de produção de blocos. Em pequena escala, o fraturamento é de efeito mais depreciativo quanto mais diferente das dimensões ótimas dos blocos para os teares, ou seus mültiplos. Considerando-se que essas dimensões são, em média de 1 x 2 x 3 metros, somente maciços ultrafraturados serão prejudicados.

$\Lambda$ evolução geomorfológica da região de Quixaba,caracterizada pela intensa desintegração física e erosão, ocasionou grande quantidade de fraturas por alívio de carga sobrejacentc c lateral. Às fraturas, bem visíveis nas elevaçõcs de rochas carbonáticas impuras, somam-se as caneluras, compondo o aspecto realmente desaprovador de uma apreciação rápida da rocha aflorante. No entanto, um exame mais detalhado mostra que o fraturamento diminui de alto a baixo das elevações e que ocorre rocha pura e homogênea nas porções baixas do corpo, encobertas pelo solo.

$\Lambda$ distribuição das impurezas, outro aspecto que po de depreciar a rocha para cantaria, também è identificada com as observações detalhadas de campo. Em vista da correlação entre cor e.composição mineral, märmores mais puros e mais homogêneos devem ser procurados em porções topogräficas conforme o tipo de clilli da região.

Em Quixaba existem dois padrões de distribuição de mármores mais e menos puros. Um é tectônico, segundo o qual 
ocorre mais märmore branco ao norte, resultante de uma deposição mais carbonātica e de ação mais intensa de metamorfismo termal, deduzida das inümeras intrusões äcidas e bäsicas e da cstrutura circular; o outro e faciológico, segundo o qual ocorre interdifitações gradativas de rochas carbonáticas mais e menos impuras, e níveis bem definidos de cravos, refletindo o acamamento ora verticalizado.os padrões de distribuição das impurezas e a geomorfologia da ärea são o principal controle para as atividades extrativas em Quixaba segundo as quais märmores puros e homogeneos devem ser procuradas em porçöes topograficamente rebaixadas quase sempre recobertas por solo. A pequena espessura do so 10 da ärea (2 metros) não chega a afetar a economicidade da extração.

Sondagens rotativas para a verificação do comportamento do fraturamento não são totalmente satisfatórias Por imprimirem esforços multidirecionais através do hasteamento a base dos testemunhos, apesar dos cuidados tomados, ocorrem inümeras rupturas de distinção difícil, ou impossível, entre maturais ou provocadas. Com Quixaba concluiu-se que sondagens, poços, trincheiras, galerias e geofísica que utilizem explosivos devem ser evitados na prospecção de cantar as, ou por destruirem a rocha, ou por produzirem prefissuramento indesejävel, alëm de encarecerem desnecessa riamente a pesquisa.

o fraturamento que foi causa de inümeras suspen sões da lavra em Quixaba, agora $\vec{c}$ tido como um elemento de valor por facilitar o desmonte de blocos, já naturalmente liberados, ou faceis de serem liberados.

$\Lambda$ existência de grande nümero de rochas com aplicações cll värios ramos industriais e a falta de uma termino logia clara c precisa tem impedido a compilação completa de dados. 
Para a realização de diagnösticos e prognösticos reais sobre o setor e preciso distinguir os conceitos petrolögicos dos industriais e comerciais.

o termo"mārmore" deve ser empregado com conotação petrogräfica, para designar rochas carbonäticas, calcíticas, dolomiticas, bem cristalizadas por metamorfismo termal. Como em outros tipos químicos de rochas, além da beleza estética, a cristalização os fazem suscetiveis de adquirir lustro pelo polimento. As demais rochas carbonaticas po dem ser tratadas como "calcärio" sedimentares ou metamórfi$\cos$.

O termo "cantaria" deve ser empregado com conotação industrial para designar o conjunto de rochas, que pelas propriedades fisicas, é capaz de adquirir lustro pelo polimento. Assim, são rochas de cantaria os märmores, grani tos, basaltos, travertinos, etc. E para os tipos 1itológicos, em peças de rochas não suscetíveis de polimento deve ser usado o termo "alvenaria". São rochas de alvenaria os arenitos, quartzitos, calcários, xistos.

As adjetivações das rochas, para identịicä-las por alguma de suas feições notảveis, são conceituações comerciais.

Boa distinção deve ser feita, tambëm, entre "blocos" e "placa" ou "chapa". Tratam-se de produtos de duas etapas bem distintas da produção da cantaria. O termo "bloco" deve ser empregado para designar a peça saída da jazida, enquanto o termo "placa" ou "chapa" deve ser utilizado para as peças resultantes da serragem dos blocos. As "placas" ou "chapas" podem ser utilizadas na forma polida ou não.

Por existir um grande nümero de rochas com aplicaçōes em värios ramos industriais, é preciso identificar as parcelas destinadas a cada um deles para o perfeito conhe- 
cimento do mercado de rochas para construção, especialmente de cantarias.

Em vista da maneira como são utilizadas (na forma maciça), os dados sobre as reservas de rochas para construção devem ser expressos em $\mathrm{m}^{3}$. 
ALMEIDA,F.F.M.de - 1967 - Origem e evolução da plataforma brasileira. Rio de Janeiro, DNPM/DGM, $36 \mathrm{p.}$ (Boletim,241).

NLMEIDA,F.F.M.de - 1969 - Diferenciação tectônica da plataforma brasileira. In: CONGRESSO BRASILEIRO DE GEOLOGIA, 23 , Salvador. Anais... Salvador, SBG, p. 29-46.

NNUKRIO INDUSTRIAL BRASILEIRO DE MARMORES E GRANITOS - 1973/ 1974. São Paulo, Emanuel, v.1.

AUBOIN,J. - 1965 - Geosynclines, Amsterdam, Elsevier, 335 p.il. AZAMBUJA,J.L.; SILVA,Z.C.G.da - 1977 - Perfil Analítico dos märmores e granitos. São Paulo, MME/DNPM, 2 v.il. (Boletim, 38).

AZliVHDO,L.G.de; TUYUAMA,V.;CUNHA,J.L.J.da - 1973 - Uso potencial da terra. da Folha SB-23 - Teresina e parte da Folha SB-24 - Jaguaribe. In: BRASIL, Departamento Nacional de Produção Mineral - PROJETO RADAM: Folha SB-23 - Teresina e parte da Folha SB-24 - Jaguaribe. Rio de Janeiro, DNPM. p.v/1 - V/25 (Levantamento de Recursos Naturais, 2). BARBOSA,G.V.; BOAVENTURA.R.S.; PINTO,M.N. - 1973 - Geomorfologia, da liolha SB-23 - Teresina e parte da Folha SB-24. Ja guaribe. In: BRASIL, Departamento Nacional de produção Mi noral. PROJETO RADAM. Folha SB-23. Teresina e parte da Fo tha SB-24. Jaguaribe, Rio de Janeiro. DNPM p.II/3 - IT/24 (Levantamento de Recursos Naturais,2).

BARROS FILHO,C.N.; MOÇO,M.F. - 1978 - Condicionamento Geolögico de Aproveitamento Econômico da Jazida de Märmore de Quixaba. PI. In: CONGRESSO BRASILEIRO DE GEOLOGIA, 30, Re cife,.. 1978. Anais...Recife, SBG, v.4, p.1744-1756. BAIIUURST, R.G.C. - 1971 - Carbonate Sediments and Their Diagnesis - Amsterdam. Elsevier, $620 \mathrm{p} . \mathrm{i} 1$. (Developments in Sedi mentology, 1.2).

BEIOUSSOV,V.V. - 1971 - Problemas básicos de gentectónica;tradução de S.Camiña e M.Cutiérrez Elorza. Barcelona, Omega, 854 p.i.l.

BENSUSAN, K.E. - 1940 - O Desenvolvimento da indústria de märmo re no Brasil.Mineração e Mctalurgia.Rio de Janeiro, 5 (27) $133-135$. 
BETEJTIN,A. - Curso de Mineralogia - Tradução de L. Vlädov, Moscu, Editoral Paz, s.d. 731 p. il.

BEURLEN,H. - 1975 - Correspondência reservada à chefia da $R$. M., sobre as jazidas de märmore de Quixaba - PI s.1.p.s. $\mathrm{c} \cdot \mathrm{p}$.

BEURLEN, K. - 1967 - A estrutura geolögica do Nordeste do Brasi1. In: CONGRESSO BRASILEIRO DE GEOLOGTA, 21, Curitiba, 1967, يnais...Curitiba, SBG, p.151-158.

BILLINGS,M.P. - 1964 - Structural Geology. 2 ed. Englewood C1iffs, Prentice - Hal1, 514 p.il.

BISSEL,H.J. \& CHILINGAR,G.V. - 1967 - Classification et sedimentares carbonate rocks - In: CHILINGAR,G.V.;BISSEL, H.J. \& FAIRBRIDGE,R.W. ed. Carbonate rocks;physica1 and chemical aspects. Amsterdam, Elsevier. p.87 - 168. (Development in Sedimentology, 9A).

BOWLES,0. - 1939 - The Stone Industries: dimension stone, construction stone, geology, tecnology, distribution, utilization, 2 ed., New York, Mc-Graw-Hi11, 519 p.i1.

BRASIL, Ministério das Minas e Energia/Departamento Nacional de Produção Mineral - 1972 a 1980 - Anuärio Mineral Brasileiro - Rio de Janeiro - Brasília, DNPM.

BRASIL, Ministêrio das Minas e Energia/Departamento Naciona1 de Produção Mineral - 1980 - Boletim de preços: - Bens Minerais e Produtos Metalürgicos, Brasilia, DNPM, 7 (35) out/nov/dez.

BRTNKMANN, R. - 1964 - Geologia Geral, tradução de Maria Lacerda - Lisboa. Fundação Calouste Gulbenkian,609, p.i1. BUILDING STONE INSTITUT - 1972 - Stone Catalog.s.c.p.

CAMPOS,M.de; BRAGA,A.de P.G.; MELLO,A.de; SANTOS,E.M.de SILVA,F.A.F.de; FRANÇA,J.B.de - 1979 - Projeto Rio Jaguaribe, Estados do Ceara, Rio Grande do Norte e Paraíba:

Relatório final de Geologia. Brasília, DNPM, 149 p.il. (Sêric Ceologia, 4. Sërie Ceologia Bäsica, 1).

CARR,D.D.; ROONEY,L.F. - 1975 - Limestone and dolomite - In: LEFOND, S.J., ed. Industrial Minerals and Rocks: non metallics other than fuels. 4 ed. rev. New York. AIME, p $757-789$. 
CARUSO,L.G.; TAIOLI,F.; FARJALLAT,J.E.S. - 1978 - Os märmores e granitos brasileiros, seu uso e suas caracteristicas tecnolögicas - Rochas de Qualidade, São Paulo, 9 (47): 36-45.

CAVALCANTi, A.M.de S. - 1951 - Tecnologia da Pedra s.1. p., Pongetti, 309 p.il.

CHILINGAR, G.V.; BISSEL, H.J.; FAIRBRIDGE, R.W. - 1967 - Carbonate Rocks - $2 \mathrm{~V}$. Amsterdam, Elsevier (Developments in Sedimentology, $9 \mathrm{~A}$ e $9 \mathrm{~B}$ ).

CREPANI, L.; MARTINI,P.R.; VENEZIANI,P.; PAIVA FILHO,A. ; MOCO,M.F. - 1977 - Mapa Geológico Preliminar do Prëcambriano do Piauí. In: SIMPOSIO DE GEOLOGIA DO NORDESTE, 8, Campina Grande, Atas, SBG.

CRUZ,W.B.; FRANÇA,H.P.M. - 1970 - Inventärio hidrolögico do Nordeste: Folha $n$ : 14 - Jaguaribe - 50. Recife, SUDENE, Div.Hidrogeologia, 222 p. i.1. (Brasil, SUDENE, Hidrogeologia 31.).

CURRIER,L.W. - 1960 - Geologic appraisal of dimension stone deposits. Washington, U.S.Government printing office, 78 p. i1. (U.S.Geological Survey Bulletin, 1109).

DANTAS,J.R.A. - 1974 - “Carta Geológica do Brasil, ao milionêsimo: lolha SB-24 - Jaguaribe e Folha SB24 - Forta1eza. BRASIL, DNPM, $74 \mathrm{p}$.

DUNBAR,C.0.; ROGERS, J. - 1966 - Principals of Stratigraphy. New York, John Wiley, $356 \mathrm{p} . \mathrm{il}$.

ETCHER, D.L. - 1969 - Tempo Goolögico, tradução de Jose Eduardo Siqueira Farjallat. São Paulo. Edgard Blücher, 172 p.i.1. (Textos Bäsicos de Geociência).

LRGUVANLT,K.; YUZER,E.; GULEC,K.; ZANBAK, C. - 1974 - A proposal for classification of marbles. In: INTERNATIONAL CONGRESS OF THE INTERNATIONAL ASSOCIATION OF ENGENEERING GBOLOGY, 2, São Paulo. Procecdings. São Paulo, ABGE, V.1. IV $-27,1 / 27$ i. 1 .

FERREIRA, A.B.Hl. - 1975 - Novo Dicionário da Lingua Portuguesa. Rio de Janeiro, Nova Fronteira, $1516 \mathrm{p}$.

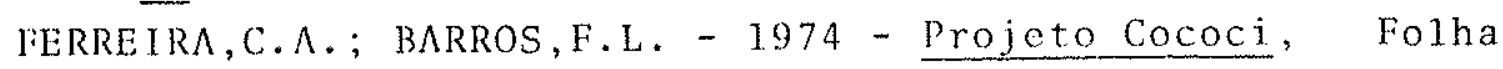
Pio IX - SB-24-Y-A-VI; relatório final, Recife, DNPM/ CPRM, v. 3 . 
FERREIRA,E.0. - 1972 - Carta Tectônica do Brasi1: nota explicativa. Rio de Janeiro, DNPM, $19 \mathrm{p}$.

FIRANCO,B.de A.; FERREIRA,J.A.de M. - 1971 - parecer acerca da jazida de märmore da COCEMI, situada no municipio de Pio IX-PI. Recife. s.c.p.

IRANCO,R.R. - 1975 - Rochas de revestimento. Rochas de Qualidade. São Paulo. ed. maio/junho 1975.

liREITAS,R.O.de - 1951 - Ensaio sobre a tectônica moderna do Brasil. São Paulo, USP, FlCL, 120 p.il. (Geologia n 6 , Boletim 130).

HASUI, Y.; ALMEIDA,F.F.M.de; NEVES, B.B.de B. - 1978 - As estruturas brasileiras. In: CONGRESSO BRASILEIRO DE GEOLOGIA. 30, Recife, 1978. Anais. Recife, SBG, v.6.p.2423 -2435 .

HURLBUT, JR.;C.S. - 1941 - Dana's Manua1 of Mineralogy.15 ed., New York, John Wiley \& Sons, 481 p.i1.

INSTITUTO DE PESQUTSAS TECNOLOGICAS DO ESTADO DE SAO PAULO S.A. - 1975 - São Paulo. Pesquisa de Mármore em Quixaba - PI. Plano de Trabalho DMGA 11/75, São Paulo,14 p.i1. INSTITUTO DE PESQUISAS TECNOLOGICAS DO ESTADO DE SÃO PAULO S.A. - 1976 A - Levantamento geolögico de detalhe do märmore na região de Quixaba-PI. (Relatōrio 9163), São paulo, 63 p. il.

INSTITUTO DE PESQUISAS TECNOLOGICAS DO ESTADO DE SAO PAULO S.A. - 1976 B - Caracterizaça tecnológica para uso em cantaria do märmore de Ruixaba-PI (Relatório interno), São Paulo, 50 p.il.

InSTITUTO DE PESQUISAS TECNOLOGICAS DO ESTADO DE SAO PAULO

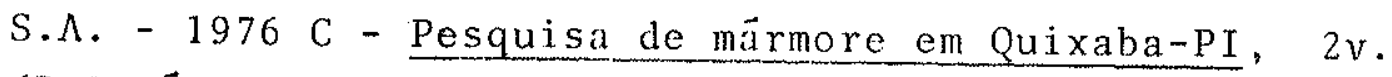
(Relatório 9541), São Paulo, 161 p.il.

INSTITUTO DE PESQUISAS TECNOLOGICAS DO ESTADO DE SAO PAULO S.A. - 1977 - Pesquisa de märmore em Quixaba - Fase II. Plano de Trabalho DMGA 131/77, São Paulo, 14 p.i.1. ITALIAN MARBLE INDUSTRIE - 1972 - $\Lambda$ technical guide to the rational use for marble. Milan, 223 p.il. 
JAPIASSU,A.M.S.; VELOSO,H.P.; GOES FILHO,L.;LEITE, P.F.-1973As regiões fitoecológicas, sua natureza e seus recursos cconômicos. Estudos fitogeogräficos da Folha SB-23-Teresina, c parte da Folha SB-24 - Jaguaribe. In: BRASIL. Departamento Nacional de Produção Mineral. Projeto RAD^M: Folha SB-23. Teresina e parte da Folha SB-24 - Jaguaribe. Rio de Janeiro, DNPM P.IV/1. IV/100. (Levantamento de recursos naturais, 2).

JUNG,J. - 1963 - Précis de pétrographie: roches sẻdimentaires, metamorphiques et eruptives. 2 ed. Paris, Masson 319 p.il.

KLGEL,W. - 1954 - Tectônica e morfologia na Serra dos Cariris Novos (Piauí-Cearả). Anais da Academia Brasileira de Ciências. Rio de Janeiro, 26 (1): 149-155, jan.

KLCiEL,W. - 1965 - A Estrutura geológica do Nordeste do Brasil. Rio de Janeiro, DNPM/DGM, 47 p.il.(Boletim,227).

KLOCKMANN, F.; RAMDOHR,P. - 1961 - Tratado de Mineralogia. Barcelona, Editorial Gustavo Gili, S.A., 736 p.il.

KRAUSKOPF,K.B. - 1972 - Introdução à Geoquímica. Tradução de Michal Lando e Paulo S.C.Bogus. São Paulo. Polígono e Liditora da USP, 2v. i1.

KRUMBEIN,W.L.; SLOSS,L.L. - 1963 - Stratigraphy and sedimentation. 2 ed., San Francisco, W.H.Freemann, 660 p.il.

LADLIRA,F.L. - 1977 - Mármores, Boletim de Minas, Lisboa, 14 (4) 187-242, out/dez.

LAPADU-HARGUES,P. - 1954 - Prëcis de minëralogie. Paris. Masson, 310 p.i1.

I.AP')R'LE,L.F. - 1975 - Ambientes antigos de sedimentação, tradução e adaptação de Sctcmbrino Petri. São Paulo, Edgard Blücher, 145 p.il. (Textos Bäsicos de Geociência).

LIBAULT, A. - 1975 - Cartografia, São Paulo. Ed. Nacional e Editora da USP, 388 p.il. (Biblioteca Universitāria,série 6aㅡ Ceografia e Ilistôria, v.1).

LINZELL,P.G. - 1973 - Relatōrio de recomendações sobre os depósitos e minas de mármore de Quixaba, estado do Piauí. Brasil - (Não editado). 
LOCZY, L.de; LADEIRA,E. - 1976 - Geologia estrutural e introdução à geotectônica. Säo Paulo - Rio de Janeiro, Edgard Blücher e Conselho Nacional de Desenvolvimento Científico e Tecnolögico, 528 p.il.

MAMET, B.L.; I'ALBISSIN,M. - 1967 - Influence of presure and temperature on limestones. In: CHILINGAR,G.V.; BISSEL, H.J.; FAIRBRIDGE,R.W.ed. Carbonate rocks; physical and chemical aspects. Amsterdam, Elsevier. p.209-223. (Developments in sedimentology, 9B).

MASON,B. - 1971 - Princípios de Geoquímica, tradução de Rui Ribeiro Franco. São Paulo. Polígono e Editora da USP, 381 p.i.1.

MAUSOLEE - 1976 - Marbres, serpentines-onyx et autres calcaires cristalines. In: Essai de nomeclature de carrières françaises des roches de construction et de decoration. Givors. Le Mausolée. p.114-135.

MLLLO,A.A.de; SOUZA,E.M.de; MENDONÇA,J.C.G. - 1978 - A tectônica 1 inear no Estado do Ceará. In: CONGRESSO BRASILLIRO DE GEOLOGIA, 30, Recife, 1978. Anais.Recife, SBG, v. 1 p. 393-407.

MENDES, F.de M. - 1974 - Condicionalismos e problemas da industria das pedras de construçäo e ornamentais: ciclo de palestras proferidas na Universidade de Luanda-Luanda, Departamento de Engenharia de Minas, 122 p.il.

MENDES, F.de M. - 1979 A - A indüstria do mármore; passado, presente e futuro. Rochas de Qualidade, São Paulo, 10 (48): 8-19, jan/fev., (49): 15-31, mar/abr., (50): 20-30 , mai/jun., (52): 6-18, set/out.

MENDES, F.de M. - 1979 B - Comercialização do märmore.Caracterização das respectiva qualidade. Otimização do aproveitamento das jazidas. Rochas de Qualidade. São Paulo, 10 (53): 5-14, nov/dez.

MIYASHIRO,A. - 1975 - Metamorphism, and metamorphic belts. London, George Allen, 492 p.il.

MOORE, R.C. - 1958 - Introduction to historical geology. 2 ed. New York, Mc-Graw-Hi11, 1957.656 p.i.1. 
MOTINOT,R. - 1972 - En Valpolice11a, le Congress de Geologie Apliquẻe a nos roches. Le Mausolée, Givors, (435):24892492 .

MOTINOT, R. - 1973 - Marbre. Le Mausolëe. Givors, (432):12551256.

MUSSA,D.; MOÇO,M.F. - 1974 - Sequências Carbonatadas de préinversão do Ciclo Brasiliano. São Paulo. (não editado) . NEVES, B.B.de B. - 1973 - Elementos da geologia Précambriana do Nordeste Oriental. In: CONGRESSO BRASILEIRO DE GEO-

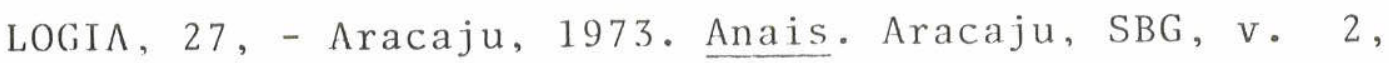
p. $105-134$.

NEVES, B.B.de B. - Regionalização geotectônica do Précambriano Nordestino, São Paulo. 198 p. (Tese de doutoramento Instituto de Geociências, USP).

NEVES, B.B.de B.; HASUI,Y.; WERNICK,E. - 1978 - As regiões de dobramentos nordeste e sudeste. In: CONGRESSO BRASILEIRO DE: CiNOELOGIA, 30, Recife, 1978. Anais. Recife, SBG. p. $2493-2507$.

NUNES, .de B.; LIMA,R.F.da F.; BARROS FILHO,C.N. - 1973-Geologia da Folha SB-23 - Teresina e parte da Folha SB-24 - Jaguaribe. In: BRASIL. Departamento Nacional de Produção Mineral - Projeto RADAM: Folha SB-23 - Teresina e parte da Folha SB-24 - Jaguaribe. Rio de Janeiro.1973. p. I/1-I/33. (Levantamento de Recursos Naturais, 2) . OLIVEIRA, J.C.; FORTES, F.P.; FERREIRA, C.A.; GOMES, H.A . ; LINS, C.A.C. - 1974 - Projeto Cococi: relatörio final.Recife, DNPM/CPRM. U.S .

PETRUCCI,E.G.R. - 1974 - Utilização de materiais naturais na construção. Rochas de Qualidade, São Paulo, (3): 17-27, sctiout.

PHILLIPS,F.C. - 1975 - La aplicación de 1a progrección estereografica em geologia estructural; version española de Carlos Martin Escorza. España, B1ume, 132 p. il.

PINUT, Secretaria de P1anejamento/Fundação Centro de Pesquisa de Mercado - 1976 - Mármores, pesquisa de mercado.Te resina, COMDEPI/CEPRO. $30 \mathrm{p}$. 
PICHLER,E. - 1942 - A petrografia e os ensaios tecnológicos das rochas. São Paulo, IPT, 26 p. il.

PICHLER,E. - 1951 - Pedra, pedregulho e areia: localização e estudo - Revista Politëcnica. São Paulo,39-45, mar/abr.

PICOCHE,J. - 1971 - Nouveau dictionaire etymologique du français. Paris, Hachette-Tchou, $827 \mathrm{p}$.

POWER,W.R. - 1975 - Construction materials: dimension and cut stone. In: LEFOND, J., ed. Industrial Minerals and Rocks: Nonmetallics other than fuels. 4 ed., New York, AIME, p. 157-174.

RAMBERG,H. - 1952 - The origin of metamorphic and metasomatic rocks: a treatise on recrystallization an replacent in the earth's crust. The University of Chicago., $317 \mathrm{p}$. i1.

RAY,R.G. - 1963 - Fotografias aéreas na interpretação e mapeamento geológico. Trad. Jesuíno Felicissimo Junior. São Paulo, Secr. da Agricultura/Instituto Geogräfico e Geolögico. $2 \mathrm{v}$.

RICCI,M.; PETRI,S. - 1965 - Princípios de aerofotogrametria e interpretação geolögica. São Paulo, Ed. Nacional. 226. p.il. (Biblioteca Universitâria, série $4 \stackrel{a}{a}, \quad$ Ciências Aplicadas, $v .2$ ).

ROSSI-MANARESI, R.; TORRACA,G. - 1972 - The treatment of stone: proceedings of the Meeting of the Joint Commitee for the Conservation of Stone, Bologna, October 1-3Bologna, Centro per la Conservazione delle Sculture

A11'Aperto. 280 p.il. (Rapporti della Soprintendenza a le Galerie de Bologna, 14).

ROSSI-MANARESI, R. - 1976 - The conservation of stone I: procedings of International Symposium, Bologna,1975. (Centro per la Conservazione delle Sculture A11'Aperto). SALVAT - 1979 - A pré-histöria. Rio de Janeiro. Salvat do Brasil, 141 p.il. (Biblioteca Salvat de Grandes Temas, $4.3)$.

SHELTON,J.E.; DRAKE,H.J. - 1975 - Stone. In: Mineral facts and problems. United States Burcau of Mines. Washington, p.1031-1048 il. (Bureau of Mines, Bull, 667). 
SINTONI,A.; VALVERDE,F.M. - 1978 - Rochas calcárias nos Estados de São Paulo e Paraná. Brasília. MME/DNPM; 131 p.il. (Boletim 45).

SOMMER,A.; ARAUJO,M.P.de; MAR'TINS,J.S.; CORREA,P.R.S. - 1973 Levantamento exploratório de solos da Folha SB-23 - Teresina e parte da Folha SB-24 - Jaguaribe. In: BRASIL, Departamento Nacional de Produção Mineral. Projeto RADAM: Folha SB-23 - Teresina e parte da Folha SB-24 - Jaguaribe. Rio de Janeiro, DNPM. p. III/1-III/133 (Levantamento de Recursos Naturais, 2).

SUSZCZYNSKI,E.F. - 1966 - Considerações sobre a evolução tectônica-orogenética da parte oriental do escudo brasileiro. Bolctim de Recursos Naturais, Recife, 4 (3/4):371-416, jul $1 / \mathrm{dez}$.

TOURENQ,C. - 1974 - Proprietées et classification des materiaux naturels de construction. In: INTERNATIONAL GONGRESS OF THE INTERNATIONAL ASSOCIATION OF ENGENEERING GEOLOGY, 2, São Paulo. Proceedings. São Paulo.ABGE, 1974, V. 1, IV-GR. 1-35.

TUREKIAN,K.K. - 1969 - Oceanos, tradução de Carlos Augusto Luciano Isotta. São Paulo. Edgard Blücher e Editora da USP, 151 p. il. (Textos Bäsicos de Geociência).

TURNER,F.J. - 1968 - Metamorphic petrology: mineralogical and field aspects. New York. McGraw-Hill, 1968. 403 p.il. (In ternational Series in the Earth and Planetary Sciences). TURNER,F.J.; VERHOOGEN,J - - 1960 - Igneous and metamorphic petrology, 2, ed. New York, McGraw-Hi11.694 p.il. (International Series in the Earth Sciences).

TUTTLE,O.F.; GITTINS,J. - 1966 - Carbonatites. London, John Wiley. 519 p.il. (Inerscience Publishers).

UNITED NATIONS, Department of Economic and Social Affairs 1976 - The development potencial of dimension stone. New York, 95 p. il.

UNITED STATES, Department of the Interior/Bureau of Mines 1978A - Minerals Yearbook 1975: area reports international. Washington U.S.Goverument printice Office, 1978 . v. 3. i1 . 
UNITED STATES, Department of the Interior. Bureau of Mines 1978B - Minera1s Yearbook 1976: meta1s, minerals and fuels. Washington U.S.Government Printing Office.v.1 il. VERMONT MARBLE: COMPANY - 1971 - Marble: color selector and use guide. Vermont. 83 p.il.

WILLINMS, II . ; TURNER, F.J . ; GILBERT,C.M. - 1970 - Petrografia: uma introdução ao estudo das rochas em seções delgadas: tradução de Rui Ribeiro Franco- São Paulo. Polígono e Editora da USP, 445 p.il.

WINKLER,E.M. - 1975 - Stone: properties, durability in man's environment 2 ed. rev, New York, Springer-Verlag, 230 p. i.1. ( $\Lambda$ pplied Mineralogy, 4).

WINKLER,H.G.F. - 1977 - Petrogênese das rochas metamórficas:

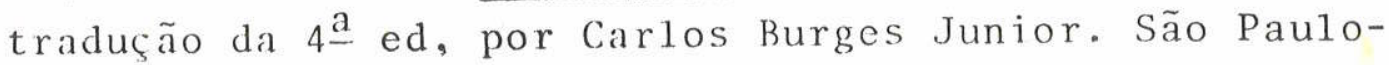
Porto $\Lambda$ legre, Edgard Blücher e Universidade Federal do Rio Cirande do Su1, 254 p.i1.

YOSIIIJA,R. - 1972 - Contribuição ao conhecimento de características tecnológicas de materiais rochosos: São Paulo. 159 p. ('l'ese de doutoramento Instituto de Geociências. USP) •

ZEZZA,U. - 1973 - Les Roches de decoration. Le Mausolée, Givors, (441) 1013-1016. 